\title{
IMPACTO AMBIENTAL E ANÁLISE ECONÔMICA DE MEDIDAS MITIGADORAS: O CASO DA MICROBACIA HIDROGRÁFICA DO CÓRREGO SÃO JOAQUIM, PIRASSUNUNGA (SP)
}

\author{
PAULO EDGARD NASCIMENTO DE TOLEDO \\ Engenheiro Agrônomo
}

Orientadora: Prof. ${ }^{a}$ Dr. ${ }^{\text {a }}$ Zilda Paes de Barros Mattos

\begin{abstract}
Tese apresentada à Escola Superior de Agricultura "Luiz de Queiroz", Universidade de São Paulo, para obtenção do titulo de Doutor em Ciências, Área de Concentração: Economia Aplicada.
\end{abstract}

\author{
PIRACICABA \\ Estado de São Paulo - Brasil \\ Fevereiro - 1997
}


Dac̛ờs internacionais de Catalogação na Publicação (CIP) DIVISÃo DE BIBLIOTECA E DOCUMENTAÇÃO - Campus "Luiz de Queiroz"/USP

\section{Toledo, Paulo Edgard Nascimento de}

Impacto ambiental e análise econômica de medidas mitigadoras : o caso da microbacia hidrográfica do córrego São Joaquim, Pirassununga (SP) / Paulo Edgard Nascimento de Toledo. - - Piracicaba, 1997.

$142 \mathrm{p}$.

Tese (doutorado) - Escola Superior de Agricultura Luiz de Queiroz, 1997. Bibliografide $: .47$

1. Impacto ambiental 2. Microbacia 3. Pirassununga, SP 4. Recuperaçāo 5. Recursos naturais I. Titulo 


\section{IMPACTO AMBIENTAL E ANÁLISE ECONÔMICA DE MEDIDAS MITIGADORAS: O CASO DA MICROBACIA HIDROGRÁFICA DO CÓRREGO SÃO JOAQUIM, PIRASSUNUNGA (SP)}

PAULO EDGARD NASCIMENTO DE TOLEDO

Aprovada em: 13.08.1997

Comissão Julgadora:

Prof.a Dr.a Zilda Paes de Barros Mattos

Prof. Dr. Paulo Yoshio Kageyama

Prof. Dr. Ricardo Shirota

Prof.a Dr.a . Yara Schaeffers Novelli

Prof. Dr. Francisco Lomba di
ESALQ/USP

ESALQ/USP

ESALQ/USP

Instituto Oceanográfico/USP

Instituto Agronômico/SAA

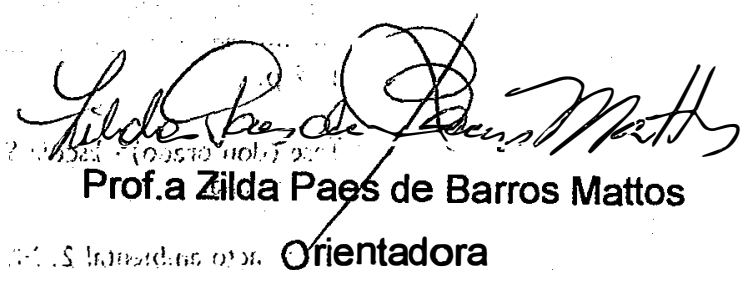




\section{SUMÁRIO}

Página

LISTA DE FIGURAS.

iii

LISTA DE TABELAS .

RESUMO

SUMMARY.

$\mathbf{x i}$

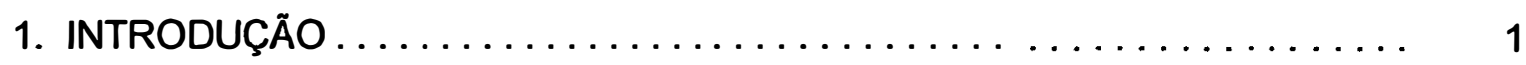

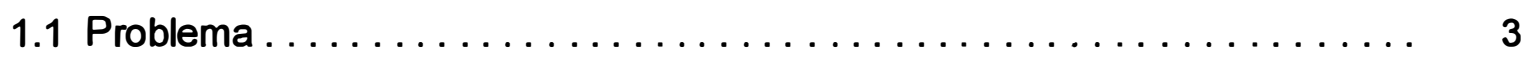

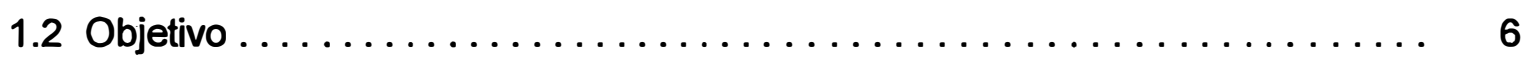

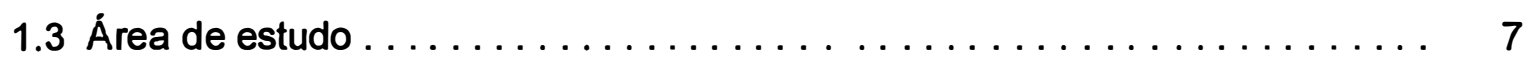

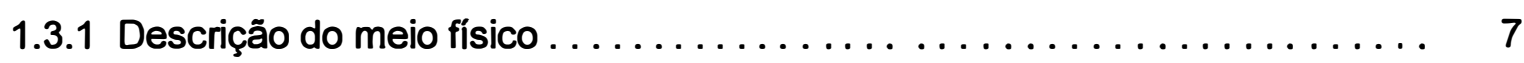

1.3.2 Caracterização sócio-econômica ....................... 9

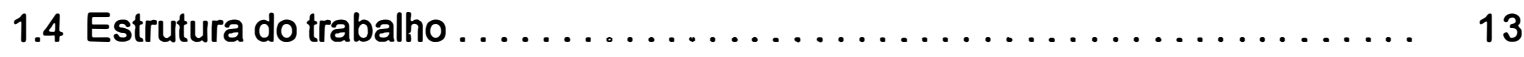

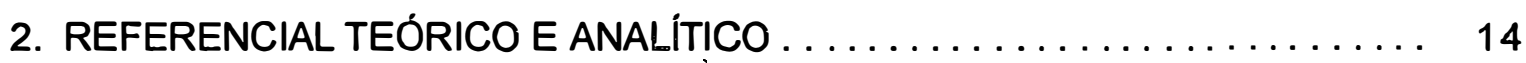

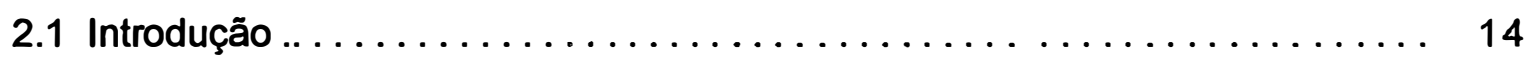

2.2 Impacto ambiental. . . . . . . . . . . . . . . . . . . . 19

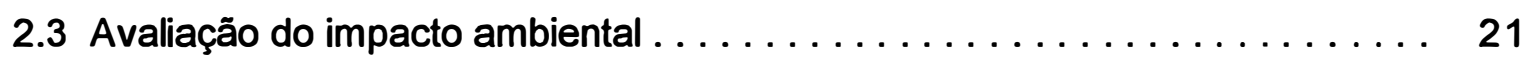

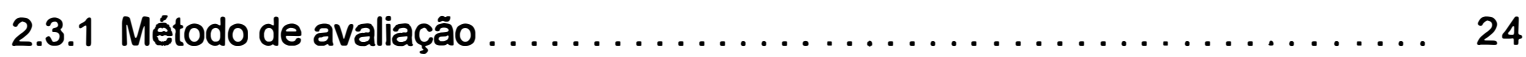

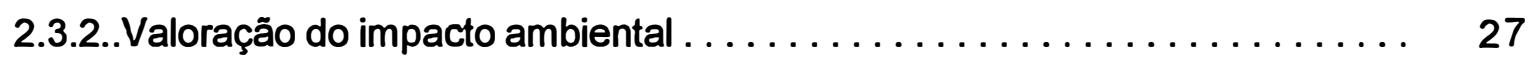

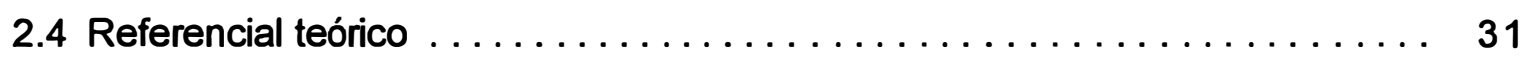

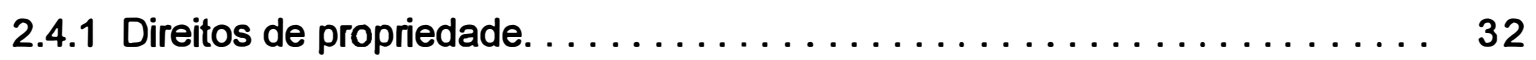

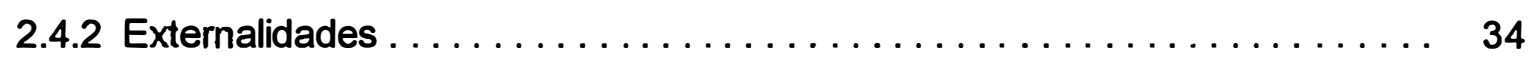

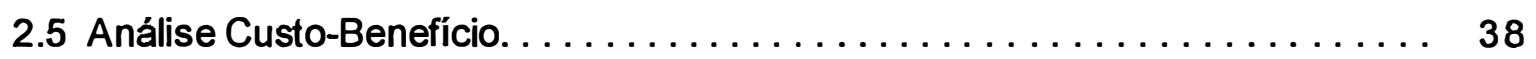

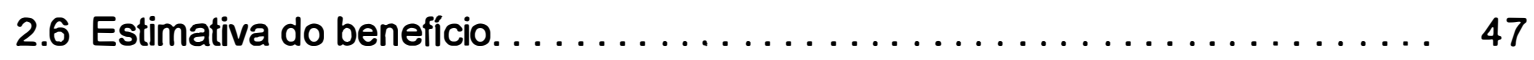

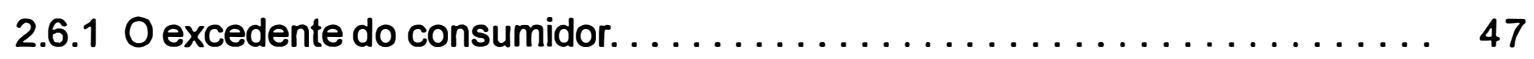


2.6.2 A especificação do modelo de demanda por água tratada . . . . . . . . . . 50

2.6.2.1 A forma funcional do modelo de demanda por água tratada . . . . . . . . . 53

2.6.2.2 Fonte dos dados. . . . . . . . . . . . . . . . . . . . . . 54

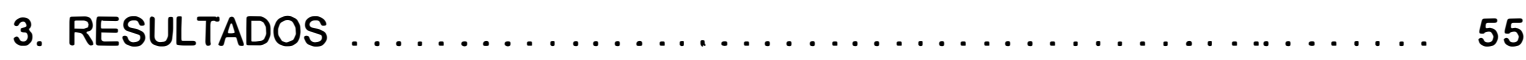

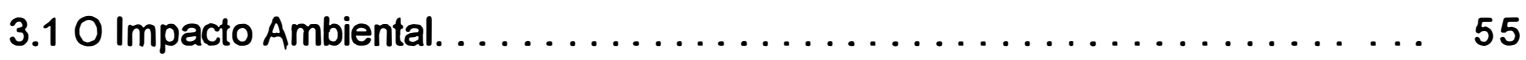

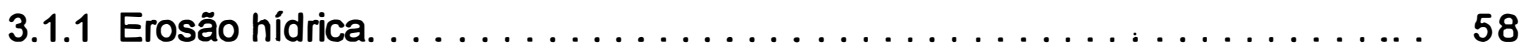

3.1 .2 Perdas de solo. . . . . . . . . . . . . . . . . . . . . . 68

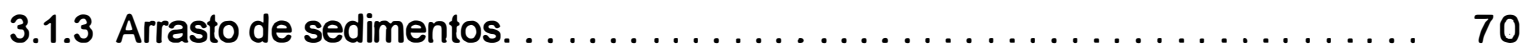

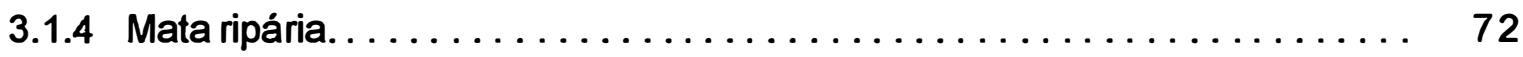

3.1 .5 Medidas mitigadoras e seus benefícios. . . . . . . . . . . . . 76

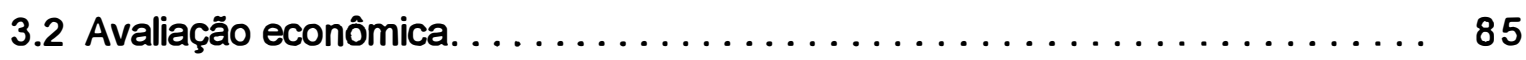

3.3 Demanda por água tratada. . . . . . . . . . . . . . . . . . . . 95

3.3.1 A estimativa da função de demanda por água tratada. . . . . . . . . . . . . 96

3.3.2 A variação do excedente do consumidor. . . . . . . . . . . . . . . 99

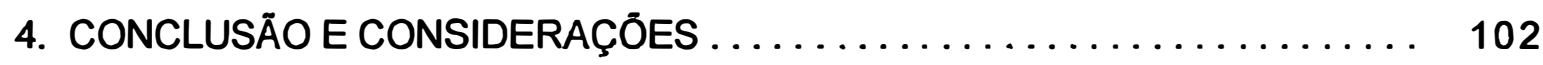

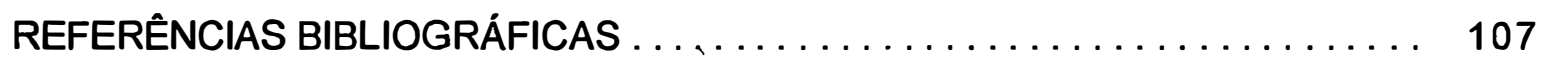

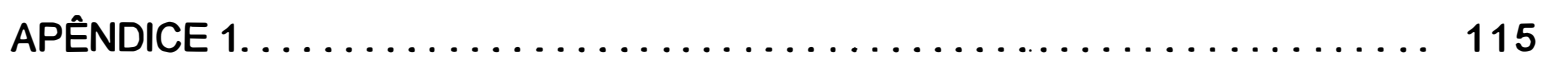

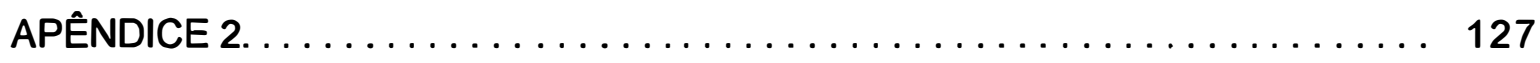

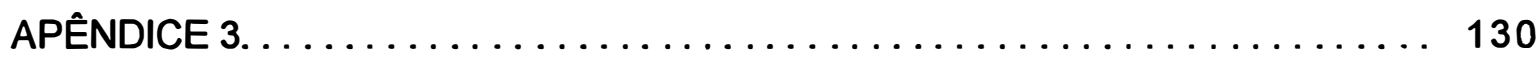




\section{LISTA DE FIGURAS}

Figura 1 Microbacia do córrego Sạo Joaquim, Pirassununga, SP.................... 8

Figura 2 Mensuração do excedente do consumidor.......................................... 47

Figura 3 Tabela de preços crescentes em blocos........................................ 51

Figura 4 Voçoroca em pastagem, microbacia do córrego São Joaquim,

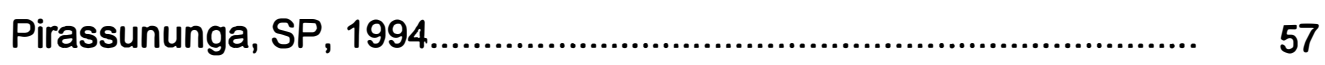

Figura 5 Assoreamento do leito do córrego São Joaquim, Pirassununga, SP, 1994.

Figura 6 Distribuição da área cultivada, segundo o tipo de exploração, microbacia do córrego São Joaquim, Pirassununga, SP, 1994.

Figura 7 Distribuição da área da microbacia do córrego São Joaquim, segundo as classes de capacidade de uso, Pirassununga, SP,. 1994

Figura 8 Distribuição da área ocupada com cana-de-açúcar, segundo a classe de capacidade de uso, microbacia do córrego São Joaquim, Pirassununga, SP, 1994.

Figura 9 Mata ripária, microbacia do córrego São Joaquim, Pirassununga, SP, 1994.

Figura 10 Distribuição da área ocupada com vegetação natural, segundo a classe de capacidade de uso, microbacia do córrego São Joaquim, Pirassununga, SP, 1994

Figura 11 Área de classe VII de çapacidade de uso com uso inadequado de pastagem, com início de processo erosivo de voçoroca, UP 58, microbacia do córrego São Joaquim, Pirassununga, SP, 1994 
Figura 12 Distribuição da área ocupada com pastagens, segundo a classe de capacidade de uso, microbacia do córrego São Joaquim, Pirassununga, SP, 1994....................................................................

Figura 13 Erosão em sulco provocada por enxurrada mal controlada, microbacia do córrego São Joaquim, Pirassununga, SP, 1994............

Figura 14 Unidades produtivas selecionadas para estudo, microbacia do córrego São Joaquim, Pirassununga, SP, 1994. 


\section{LISTA DE TABELAS}

Tabela 1 Formas de exploração da terra, em hectare, microbacia do córrego São Joaquim, Pirassununga, 1994.

Tabela 2 Número de propriedades e área total por estrato de área, em hectares, microbacia do córrego São Joaquim, Pirassununga, 1994.

Tabela 3 Área das principais culturas anuais e perenes, em hectare, microbacia do córrego São Joaquim, Pirassununga, 1994.

Tabela 4 Área e porcentagem das diferentes unidades de solo mapeadas na microbacia do córrego São Joaquim, em hectare, Pirassununga, SP

Tabela 5 Distribuição da área da microbacia do córrego São Joaquim, segundo classes de declividade, em porcentagem de inclinação, Pirassununga, SP, 1994

Tabela 6 Área das atividades exploradas, por classe de capacidade de uso, microbacia do córrego São Joaquim, Pirassununga, SP, 1994

Tabela 7 Áreas exploradas com atividades adequadas à classe de capacidade de uso, microbacia do córrego São Joaquim, Pirassununga, SP, 1994...

Tabela 8 Áreas exploradas com atividades pouco adequadas à classe de capacidade de uso, microbacia do córrego São Joaquim, Pirassununga, SP, 1994.

Tabela 9 Áreas exploradas com atividades que sub-utilizam a capacidade de uso do solo, microbacia do córrego São Joaquim, Pirassununga, SP, 1994...

Tabela 10 Áreas exploradas com atividades inadequadas à classe de capacidade de uso, microbacia do córrego São Joaquim, Pirassununga, SP, 1994... 
Tabela 11 Área, erodibilidade e tolerância de perdas para as unidades de solo da microbacia do córrego São Joaquim, Pirassununga, SP

Tabela 12 Estimativa do valor média do parâmetro C para o uso atual do solo da microbacia do córrego Sãa Joaquim, Pirassununga, SP, 1994

Tabela 13 Estimativa da área indicada para recomposição da mata ripária, microbacia do córrego São Joaquim, Pirassununga, SP, 1994.

Tabela 14 Adequação às classes de capacidade de uso das glebas da microbacia do córrego São Joaquim, em hectare, Pirassununga, SP

Tabela 15 Estimativa da variação do volume de água escorrida por enxurradas, sem e com adequação às classes de capacidade de uso, microbacia do. córrego São Joaquim, Pirassununga, SP, 1994.

Tabela 16 Alterações da adequação ambiental e taxas internas de retorno, microbacia do córrego São Joaquim e unidades selecionadas, Pirassununga, SP

Tabela 17 Fluxo de caixa, valor presente líquido e taxa interna de retorno, microbacia do córrego São Joaquim e unidades selecionadas, com encargo da recomposição da mata ripária.

Tabela 18 Fluxo de caixa, valor presente líquido e taxa interna de retorno, microbacia do córrego São Joaquim e unidades selecionadas, sem encargos da recomposição da mata ripária.

Tabela 19 Valores obtidos no ajuste da função aos dados de consumo de água tratada, Pirassununga, 1988-96.

Tabela 20 Estimativa da relação entre a remoção da camada superficial do solo e o respectivo declínio de produtividade. 
Tabela 21 Estimativa da taxa de declínio da produtividade devido à erosão da camada superficial, por țipo de solo, microbacia do córrego São Joaquim, Pirassununga, SP

Tabela 22 Exigência básica de fatores da produção da cultura do algodão, 1 hectare, microbacia do córrego São Joaquim, Pirassununga, SP, 1994

Tabela 23 Exigência básica de fatores da produção da cultura de cana-de-açúcar, 1 hectare, microbacia do córrego São Joaquim, Pirassununga, SP, 1994.

Tabela 24 Exigência básica de fatores para a manutenção da cultura de citros, 1 hectare, microbacia do córrego São Joaquim, Pirassununga, SP, 1994

Tabela 25 Exigência básica de fatores da produção de leite, microbacia do córrego São Joaquim, Pirassununga, SP, 1994.

Tabela 26 Exigência básica de fatores da produção da cultura de milho, 1 hectare, microbacia do córrego São Joaquim, Pirassununga, SP, 1994

Tabela 27 Exigência básica de fatores da produção da cultura de soja, 1 hectare, microbacia do córrego São Joaquim, Pirassununga, SP, 1994

Tabela 28 Orçamentos anuais da cultura de algodão, microbacia do córrego São Joaquim, Pirassununga, SP, 1994

Tabela 29 Orçamentos anuais da cultura da cana-de-açúcar, microbacia do córrego São Joaquim, Pirassununga, SP, 1994.

Tabela 30 Orçamentos anuais da cultura de citros, módulo de 14,8ha, microbacia do córrego São Joaquim, Pirassununga, SP, 1994 
Tabela 31 Orçamentos anuais da pecuária leiteira, módulo de 14ha , microbacia do córrego São Joaquim, Pirassununga, SP, 1994.

Tabela 32 Orçamentos anuais da cultura de milho, microbacia do córrego São Joaquim, Pirassununga, SP, 1994

Tabela 33 Orçamentos anuais da cultura da soja, microbacia do córrego São Joaquim, Pirassununga, SP, 1994. 


\title{
IMPACTO AMBIENTAL E ANÁLISE ECONÔMICA DE MEDIDAS MITIGADORAS: O CASO DA MICROBACIA HIDROGRÁFICA DO CÓRREGO SÃO JOAQUIM, PIRASSUNUNGA (SP)
}

\author{
Autor: Paulo Edgard Nascimento de Toledo \\ Orientadora: Prof. ${ }^{a}$ Dr. ${ }^{\text {a }}$ Zilda Paes de Barros Mattos
}

\section{RESUMO}

Este trabalho analisa, sob o ponto de vista econômico, a viabilidade de medidas mitigadoras para controlar externalidades causadas pela produção agropecuária na microbacia do córrego São Joaquim, manancial para o abastecimento urbano de água tratada de Pirassununga, no Estado de São Paulo.

Apresenta como objetivos principais as avaliações de alguns impactos ambientais e a econômica de projeto de conservação do solo, tanto para a área como um todo, como para as unidades produtivas mais relevantes. Os estudos técnicos de avaliação do impacto ambiental, bem como o de recuperação através de medidas mitigadoras, foram realizados mediante tratamento informático de cartografia. Foram usados mapas da distribuição dos tipos de solo, da declividade e da ocupação atual pela agropecuária, gerando o potencial natural de uso e de erosão. Para os $3.044,47$ hectares analisados, os resultados mostram, embora com restrições de manejo, $61,5 \%$ das atuais atividades agropecuárias sendo realizadas adequadamente em relação à classe de capacidade de uso das respectivas glebas. Do restante, $3,6 \%$ acha-se pouco adequado, enquanto que $17,7 \%$ da área total é sub-utilizada. $A$ situação mais preocupante, em termos de impacto ambiental, refere-se aos $17,2 \%$ que estão sendo ocupados de maneira sobre-utilizada, ou seja, com destinação de uso superior à aptidão agrícola. Como conseqüência à não observância da aptidão agrícola de parte das glebas, e ao não uso das práticas de manejo e conservação nas demais, evidencia-se o impacto ambiẹtal através da excessiva turbidez das águas, sinais de voçoroca e de erosão em sulcos, diminuição da produtividade dos principais 
aqüiferos da microbacia e resultante aumento da amplitude da vazão média do córrego.

A proposta de medidas mitigadoras para reduzir o impacto a padrões que permitam a reciclagem dentro do próprio sistema ambiental mostrou-se economicamente viável, com valores presentes líquidos positivos, considerado o horizonte de projeto de 20 anos e taxas de desconto à $6 \%$, tanto para a microbacia toda como para a maioria das unidades produtivas. Todavia, propriedades localizadas nas partes com maior declividade apresentaram como resultado taxas negativas. Tais resultados sugerem que os proprietários podem ter diferentes graus de estímulo ao engajamento em programas ambientais para suas empresas.

O estudo estimou também, a função de demanda por água tratada pelos munícipes de Pirassununga. Seus parâmetros permitiram calcular o valor do benefício social resultante do aumento de vazão do córrego, através da variação do excedente do consumidor, o qual pode vir a se equiparar com o custo das medidas mitigadoras, criando a perspectiva para uma negociação da adequação ambiental entre os proprietários e os munícipes, desde que induzida. 


\section{THE ENVIRONMENTAL IMPACT AND ECONOMIC ANALYSIS OF MITIGATING ACTIONS: THE CASE OF SÃO JOAQUIM STREAM'S WATERSHED, PIRASSUNUNGA, STATE OF SÃO PAULO.}

Author: Paulo Edgard Nascimento de Toledo Adviser: Prof ${ }^{\text {. Dr }}$. Zilda Paes de Barros Mattos

\section{SUMMARY}

This study analyses from the economic viewpoint, the feasibility of mitigating actions for controlling externalities caused by agricultural production in the São Joaquim watershed. This watershed is the source of urban treated water for Pirassununga, State of São Paulo.

It presents, as its main objectives, the environmental impact and economic evaluations of an environmental recovery project. It also presents an analysis for the area as a whole and for the most revelant productive units within the area.

The technical evaluation studies of the environmental impact as well as the environmental recovery program were achieved through mitigation actions. This evaluation was carried out with the aid of a geographical information system (GIS). This system utilized the following maps: i) distribution of soil type; ii) slope; and iii) current soil use. The most important determining factors, natural potential of use and erosion of the soil, were found through superimposing and analyzing the three maps. The results were based on a study of the entire watershed $(3,044.47$ hectares).

The findings showed that $61.5 \%$ of present agricultural enterprises were properly cultivated with respect to soil capacity use. For the remaining area, $3.6 \%$ was not quite properly cultivated, while $17.7 \%$ of the area was found to be underutilized. The most serious situation in terms of environmental impact concerns $17.2 \%$ of the area which are being overutilized, that is to say, it is being used above its agricultural vocation.

As a consequence of disregarding the soil capacity use, the excessive muddy water in the São Joaquim stream reveals the environmental impact. 
Furthermore, furrow erosion, declines in soil productivity and increases in flooding are also observed.

The conservation project proposed shows a positive net present value, for a 20-year planning horizon at $6 \%$ discount rate. This applies to the entire watershed and to the most productive units analyzed. However, farms located on the steepest parts of the watershed show negative internal return rates. This indicates that farmers may have different degrees of motivation to engage in environmental programs.

This study also estimates the demand function for treated water for Pirassununga's urban residents. Its parameters allow an estimation to be made of the social net benefit resulting from the increase in the stream's flow for treatment. This was measured through the variation of consumer surplus. The results indicate the possibility of net social benefit to be compared with the cost of mitigation actions, thus creating a perspective for the negotiation of environmental adequacy between farmers and urban consumers, once induced. 


\section{INTRODUÇÃO}

Este trabalho analisa, sob o ponto de vista econômico, a viabilidade de medidas mitigadoras para controlar externalidades causadas pela produção agropecuária na microbacia do córrego São Joaquim, manancial para o abastecimento urbano de água tratada de Pirassununga, Estado de São Paulo.

Do ponto de vista ambiental, a ocupação do território brasileiro para fins agropecuários deu-se de forma semelhante à de outras fronteiras agrícolas: sem a preocupação com a preservação de solo e água. Naturalmente, a então abundância destes recursos não induzia implementação de políticas e modelos institucionais para racionalizar o uso dos mesmos.

Mais recentemente, com o ciclo de desenvolvimento iniciado nos anos sessenta, juntamente com o esgotamento de novas fronteiras agrícolas, passa a predominar uma constante busca por produtividades ascendentes na agricultura através dos chamados "insumos modernos" (sementes melhoradas, fertilizantes, defensivos e mecanização). $O$ uso dessa nova tecnologia provocou externalidades tanto no próprio meio rural e como no meio urbano.

No meio rural, pode-se ressaltar, em alguns casos, a degradação da capacidade produtiva dos solos como conseqüência da intensa mecanização dos processos produtivos. Nestes casos, é provável que a causa principal resida na falta de maior preocupação com a adoção concomitante de práticas necessárias para a preservação e controle da erosão dos solos, principalmente daqueles expostos pela derrubada das florestas nativas. Dentre estas práticas, pode-se citar, por exemplo, a 
inobservância das classes de capacidade de uso solo, tecnologia disponivel desde 1936.

A destruição sistemática de sistemas ambientais primitivos (principalmente os florestais) resultou da necessidade de liberação de espaços para atividades urbanas e rurais, bem como para infra-estrutura, transporte, energia, etc. Segundo Veiga Filho et al. (1992), "originalmente $80 \%$ da área total do Estado de São" Paulo era coberta com florestas naturais, ou seja, cerca de 20 milhões de hectares. Atualmente há ao redor de 2,4 milhões de hectares com florestas, sendo 1,1 milhão de hectares de matas naturais localizadas em sua grande maioria na Serra do Mar. Além disso, cerca de $62 \%$ da área total do Estado, constantemente cultivada, tem a maior parte de seus solos classificada nas capacidades de uso III e IV, devido à sua fragilidade estrutural, requerendo portanto, o emprego de vánas práticas consenacionistas" (p.134). Os autores alertam ainda sobre "ocorrência de problemas de perda de estrutura, compactação, erosão profunda e laminar, de excessiva perda de água por escorrimento, de voçorocas e de assoreamento de vánias áreas e rios" (p.137). Dados da Secretaria de Agricultura e Abastecimento (SAA) do Estado de São Paulo (SAA, 1989) apontam um potencial de erosividade muito alto para os solos do Estado. A distribuição das chuvas é um dos fatores determinantes, pois uma concentração entre outubro e março (de $74 \%$ a $94 \%$ ) coincide com o período de maior mobilização do solo por tratos culturais. Como agravante ao risco pluviométrico apontam também o fato de $60 \%$ do território paulista ser susceptível à erosão devido às suas características físico-químicas. A erosão hídrica ocorre em $80 \%$ das áreas estaduais cultivadas e tem sido apontada como a principal causa da deterioração dos solos (Bellinazzi Jr. et al., 1981). Essa perda, segundo os autores, representava, em 1981, um volume equivalente a 194 milhões de toneladas anuais de solo, com $25 \%$ transportadas diretamente para mananciais.

Para as propriedades, há perdas de solo e de nutrientes, enquan'to o fluxo de sedimentos, ao atingirem córregos, rios e barragens, ocasiona modificações no sistema de deflúvio e problemas ap meio ambiente. $O$ depósito de sedimentos leva à redução da capacidade dos córregos e reservatórios; elevação nos custos de oferta de água tratada; danos para a fauna silvestre e aquática; acréscimos nos custos de 
manutenção de canais e rios navegáveis, diminuição do potencial hidroelétrico; problemas na irrigação e na drenagem; acréscimos nos custos de manutenção das estradas; prejuízos causados pelas enchentes. Além disso, como reduz-se a infiltração de água no solo, ocorre aumento no volume da enxurrada. Com isto, tornam-se mais freqüentes as súbitas elevações de vazão e cresce a poluição devido às maiores quantidades de resíduos conduzidos aos cursos d'água: partes de plantas, dejetos de animais, fertilizantes químicos e pesticidas.

\subsection{Problema}

As dificuldades no abastecimento de água no município de Pirassununga, no Estado de São Paulo, ilustram bem este tipo de externalidade causada pela agricultura. Em 1986, o Prefeito levou o seguinte problema para a SAA: as águas do córrego continham excessiva quantidade de resíduos de solo em suspensão promovendo desgaste nos equipamentos de bombeamento, inutilizando-os prematuramente.

$\mathrm{Na}$ busca de uma solução, a SAA, após levantamento expedito de dados, elaborou projeto emergencial para conter o processo erosivo detectado. Inicialmente foram realocadas estradas internas e apontadas medidas mitigadoras para controle da erosão. As ações diretas do governo local e/ou da SAA ocorreram de acordo com os cronogramas propostos e provocaram imediata melhoria na qualidade das amostras de água. Todavia, as ações de caráter individual, a cargo dos proprietários, não apresentaram desempenho semelhante, e muitas deixaram de ser executadas, embora com constante apoio daquelas instituições governamentais.

Em recente diagnóstico sobre a situação do uso agrícola daquela microbacia, Otani et al. (1996) observaram que "as pesquisas realizadas pelo Instituto Agronômico de Campinas (IAC) constataram uma necessidade de adequação das práticas de manejo às condições locais, onde os problemas de erosão estão mais relacionados com manejo do que com outros fatores como tipo e fertilidade do solo ou 
posição no relevo (p.49)", indicando que as perdas de solo referem-se mais a ausência de práticas conservacionistas. Relataram também que, segundo informes do serviço de abastecimento de água do município, imediatamente nos anos seguintes à implantação do programa não houve necessidade de dragagem do leito do córrego. Todavia, em 1995 esta prática teve que ser retomada pois a deposição de areia elevou o leito do córrego a níveis críticos, provavelmente pela combinação de chuvas acima do normal com a falta de conservação dos terraços e dos canais escoadouros construídos na microbacia.

Estes fatos comprovam, no primeiro instante, a eficácia das medidas sugeridas no programa de conservação proposto e executado. Através deste, estradas e propriedades foram trabalhadas com máquinas e outros recursos do Governo. Em um segundo momento, os fatos demostram a necessidade de medidas mitigadoras para reduzir a perda de solo e permitir um cultivo sustentável.

Como principais causas para o insucesso, Otani et al. (1996) apontam: a) segundo a coordenação do programa estadual, os produtores não foram devidamente esclarecidos; b) foram determinantes a inexistência de uma comissão de produtores representativa e participativa, e o fato de, naquela oportunidade, a maioria dos produtores achar-se descapitalizada; e c) a ausência de técnico responsável pelo trabalho na microbacia por um periodo de dois anos. Entretanto, ainda segundo os autores, "dingentes da extensão afirmam que a implantação da mata ciliar não avançou porque os produtores não se dispuseram a destinar parte das terras para esse fim, e alertam para a necessidade de um trabalho de esclarecimento e conscientização dos produtores".

Acredita-se que nesta última observação venha a residir um dos fatores determinantes pela relativa passividade por parte dos produtores envolvidos. Esta constatação é o reflexo de uma tomada de decisão, por parte dos proprietários, baseada em suas análises de custos e benefícios das ações mitigadoras para conter as externalidades provocadas pelas respectivas atividades agropecuárias. Explicitando, os produtores não se sentem atraídos em participar de programas onde 
não venham a receber alguma compensação pelos gastos decorrentes da adoção das práticas conservacionistas que thes são cobradas. Ressalte-se ainda, que as diferentes localizações das unidades produtivas dentro da microbacia, implicando em diferenças significativas de relevo e tipo de solo, podem resultar em diferentes custos e benefícios. Tal fato, conseqüentemente se traduz em diferentes referenciais para a tomada de decisão, e provoca distintos graus de indução ou repulsa ao engajamento no programa.

Por outro lado, as políticas e modelos institucionais voltados para o consumidor urbano de água não têm conseguido estimular a adoção de medidas de conservação do recurso, mesmo com o preço cobrado por $\mathrm{m}^{3}$ aumentando na razão direta do volume consumido. Nestes casos os preços parecem não terem sido estabelecidos com base em custos reais de captação, tratamento e distribuição do recurso. A este respeito, é oportuno lembrar que estudos aplicados em outros países mostraram que aumentos de preços provocam mudanças nas quantidades demandadas de água (Gibbons, 1989).

Em suma, as técnicas utilizadas na produção agropecuária do município estão afetando a oferta de água para os consumidores urbanos. O governo local decidiu atacar o problema diretamente, tentando eliminar as externalidades causadas por aquela produção. Subsidios dos governos local e estadual foram utilizados num programa de incentivos à conservação do solo, aparentemente mal sucedido.

Em se tratando de recursos naturais, a manifestação destas dificuldades é esperada, pois assumem grande expressão as chamadas "falhas de mercado". Neste caso, as circunstâncias envolvem problemas relacionados com atenuação de direitos de propriedade e não-exclusividade no consumo, melhor discutidos na fundamentação teórica deste trabalho.

Mas o mercado de "serviços de preservação e produção de recursos ambientais", se é que se pode assim denominá-lo, é emergente e deverá firmar-se, organizar-se e crescer institucionalmente nas sociedades sob regime capitalista. Portanto se essas sociedades manifestam o caráter urgente da recuperação e da 
preservação ambiental pela ameaça à sua própria existência, cumpre a seus membros promover e propiciar soluções alternativas.

Neste contexto inserè-sé éste éstudo, cujo principal objetivo consiste ná determinação, pelo lado da oferta de preservação ambiental, do custo da conservação e/ou récuperação ambiental e consequäentes benefícios oriundos do aumento e melhoria de qualidade da oferta de água para os munícipes de Pirassununga, Estado de São Pauló.

$\mathrm{Na}$ solução de problemas desta natureza torna-se importante explicitar as questões ambientais da perda de solo e da poluição de rios decorrentes da atividade agropecuária. Qual o papel social, as ações específicas, as responsabilidades (e respectivos ônus e benefícios) decorrentes de uma negociação, mediada pelo governo, entre poluidores e os que sofrem com a poluição? Embora não seja pretensão deste estudo responder integralmente a questões tão complexas como essas, espera-se, de alguma maneira, estar contribuindo para a discussão do controle da atividade agropecuária como fonte não pontual de poluição.

O tema seria a adoção de medidas mitigadoras para conter o ocasionado pela não observância, no uso agrícola do solo, dos limites de tolerância de um sistema ambiental, em uma microbacia hidrográfica.

\subsection{Objetivo}

O objetivo principal deste trabalho foi avaliar, para unidades produtivas e para a microbacia como um todo, a viabilidade econômica da adoção de medidas mitigadoras para controlar a perda do solo e deterioração dos aquiferos, causados pelo uso agrícola inadequado do solo na microbacia do Córrego São Joaquim, municipio de Pirassununga. Também estima o valor do benefício que os consumidores urbanos de água tratada obteriam com a adoção das medidas mitigadoras propostas. 
Mais especificamente pretendeu-se:

a) avaliar parte do impacto ambiental decorrente do atual processo produtivo agropecuário usado na microbacia, com a identificação dos danos físicos causado pelo uso inadequado do solo e a ausência de mata ripária ;

b) verificar a viabilidade econômica de um projeto de recuperação ambiental da microbacia do córrego São Joaquim, pela adoção das medidas mitigadoras, seja para a microbacia como um todo, como também para unidades produtivas representativas;

c) estimar 0 valor dos benefícios que os munícipes obteriam pelo aumento da quantidade ofertada de água ;

d) dar subsídio a uma política agrícola para estímulo à recuperação e preservação a outras microbacias com impactos semelhantes.

\section{3 Área de estudo}

A área de estudo acha-se localizada no município de Pirassununga, região nordeste do Estado de São Paulo, distante $210 \mathrm{~km}$ da capital ao utilizar-se como acesso a rodovia Anhanguera (Figura 1).

\subsubsection{Descrição do meio físico}

Geomorfologicamente, a microbacia do córrego São Joaquim acha-se inserida no segmento geológico denominado Depressão Periférica. Seu ponto de descarga , ao desembocar no córrego do Descaroçador, dá-se ao lado direito da rodovia Anhanguera, no sentido interior-capital, a cerca de $1.600 \mathrm{~m}$ do trevo de acesso à 


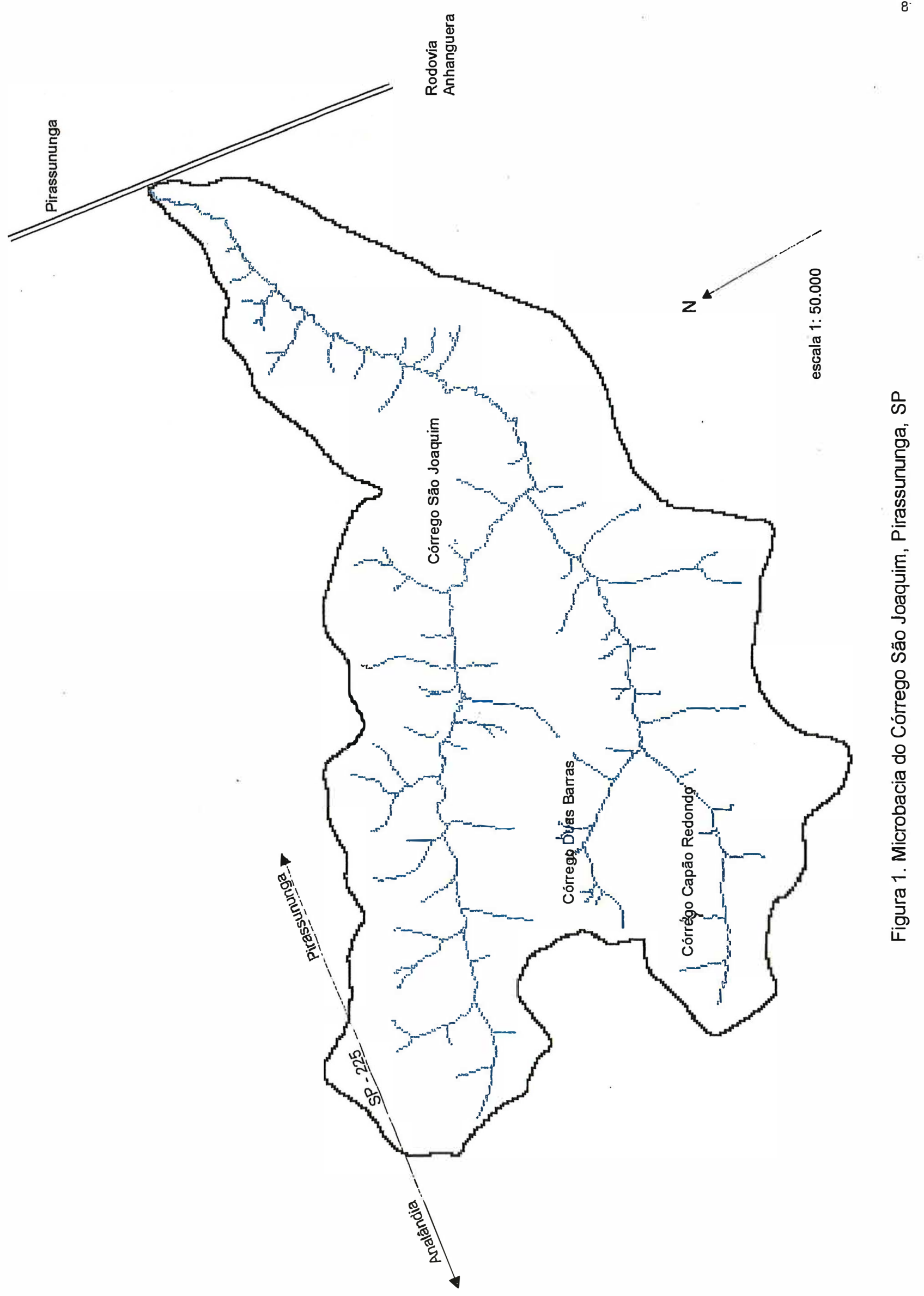


cidade de Pirassununga. O eixo principal de deflúvio está orientado no sentido de oeste para leste, e compreende cerca de $10 \mathrm{~km}$ entre seu ponto de descarga, na direção oeste, e os divisores de água de seus dois afluentes: córregos Salto Grande e Duas Barras. Do ponto de vista hidrológico, a microbacia está sucessivamente inserida nas bacias dos rios Moji e Grande, as quais, por sua vez, são componentes da macrobacia do rio Paraná.

As características climáticas da microbacia do córrego do São Joaquim, segundo Köppen, são do tipo Cwa (clima subtropical de altitude), com inverno seco e chuvas no verão. Janeiro e fevereiro se caracterizam como os meses mais quentes, quando a temperatura média atinge em torno de $24^{\circ} \mathrm{C}$, sendo que no mês mais frio (julho) a média atinge $18^{\circ} \mathrm{C}$ e a precipitação média não ultrapassa $30 \mathrm{~mm}$. As maiores precipitações ocorrem nos meses de dezembro e janeiro quando, em média, as chuvas chegam à $242 \mathrm{~mm}$ e $238 \mathrm{~mm}$, respectivamente. Em anos considerados normais, o balanço hídrico climático aponta seqüências de excesso hídrico de dezembro a março; de deficiência hídrica de maio a setembro; e, de equilíbrio em abril e outubro.

A área delimitada apresenta com maior presença, relevo suavemente ondulado a ondulado (declives de $2 \%$ a $20 \%$ ), cujas vertentes chegam a atingir $1.500 \mathrm{~m}$ de extensão. Levantamento detalhado da microbacia do córrego São Joaquim revelou uma grande variabilidade de solos. Foram identificadas 21 diferentes unidades, com predominância de solos podzólicos e latossólicos, ocupando cerca de $40 \%$ e $38 \%$ da área total, respectivamente.

\subsubsection{Caracterização sócio-econômica}

$\mathrm{Na}$ microbacia do Córrego São Joaquim acham-se localizadas 66 propriedades rurais, cujas áreas totais ocupam $3.576,86 \mathrm{ha}$, sendo $3.044,47$ ha dentro dos limites estabelecidos pelos divisores de água da microbacia. Em 92,34\% das propriedades, a agropecuária é a atividade principal. As demais destinam-se à fabricação de tijolos (2), à recreação (1) e uma encontra-se sem atividade. 
As unidades administradas e trabalhadas pelo proprietário são maioria, e perfazem cerca de $70,51 \%$ da área total da microbacia. As terras exploradas via arrendamento somam $891,95 \mathrm{ha}(24,94 \%)$, e destinam-se principalmente ao cultivo da cana-de-açúcar $(79,59 \%$ das terras arrendadas). O acesso à terra, através da parceria, também é uma prática utilizada, porém com menor significância, abrangendo cerca de 162,93 ha $(4,55 \%$ do total da área), destinados, basicamente, a pasto e milho (Tabela 1).

Tabela 1. Formas de exploração da terra, em hectare, microbacia do córrego São Joaquim, Pirassununga, 1994

\begin{tabular}{lrr}
\hline Forma de expoloração & \multicolumn{1}{c}{ Área } & \multicolumn{1}{c}{$\%$} \\
\hline Proprietário & $2.521,98$ & 70,51 \\
Arrendatário & 891,95 & 24,94 \\
Parceiro & 162,93 & 4,55 \\
\hline Total & $3.576,86$ & 100,00 \\
\hline
\end{tabular}

Fonte: Otani et al. (1996).

Em relação à estrutura fundiária, verifica-se que predominam as propriedades rurais com área de até 30ha; estes estabelecimentos menores acomodam-se em cerca de 677,35 ha, correspondendo a $18,95 \%$ da área da microbacia. As propriedades com mais de 100 ha de área (em número de 11) ocupam $61,44 \%$ da área da microbacia. (Tabela. 2)

Tabela 2. Número de propriedades e área total por estrato de área, em hectares, microbacia do córrego São Joaquim, Pirassununga, 1994

\begin{tabular}{rrrrr}
\hline \multicolumn{1}{c}{ Estrato } & Número & \multicolumn{1}{c}{$\%$} & \multicolumn{1}{c}{ Área } & $\%$ \\
\hline $0,1-10,0$ & 15 & 22,73 & 85,02 & 2,38 \\
$10,1-20,0$ & 9 & 13,64 & 139,12 & 3,89 \\
$20,1-30,0$ & 18 & 27,27 & 453,21 & 12,68 \\
$30,1-40,0$ & 5 & 7,58 & 174,52 & 4,88 \\
$40,1-50,0$ & 2 & 3,03 & 91,96 & 2,57 \\
$50,1-100,0$ & 6 & 9,09 & 435,16 & 12,17 \\
$100,1-200,0$ & 5 & 7,58 & 632,54 & 17,68 \\
$>\quad 200,0$ & 6 & 9,09 & $1.565,86$ & 43,76 \\
\hline Total & 66 & $3.576,86$ & 100,00 & 100,00 \\
\hline
\end{tabular}

Fonte: Otani et al. (1996). 
A área com atividades agropecuárias é de $3.345,82$ ha, da qual $41,64 \%$ é explorada com culturas anuais, $26,70 \%$ com culturas perenes e $27,19 \%$ com pastagens. Há ainda $4,47 \%$ com outros usos, constituídos basicamente por matas naturais $(84,29$ ha) e reflorestamentos com eucalipto $(40,56 \mathrm{ha})$.

$\mathrm{Na}$ análise das principais culturas da microbacia, em termos da área ocupada, observa-se que três atividades se destacam: pastagem, citros e cana-deaçúcar. $\mathrm{O}$ algodão, cultura outrora com destaque na economia regional, vem perdendo espaço, ocupando em 1994 apenas 1,83\% da área total da microbacia (Tabela 3).

Quanto à freqüência de cultivo nos estabelecimentos, pastagem foi encontrada em 42 propriedades ( $68,85 \%$ do total), com área média de 21,66 ha, e com $50,0 \%$ das propriedades apresentando área de pasto entre 0,5 e 10,0 ha. O total do rebanho declarado na microbacia, no período, foi de 1.042 cabeças, demonstrando a baixa capacidade suporte das pastagens ( 0,86 cabeça por hectare). A pecuária é uma atividade mantida pela maioria dos produtores, porém de forma secundária. Em apenas algumas das propriedades ela se apresenta como importante fonte de renda.

Tabela 3. Área das principais culturas anuais e perenes, em hectare, microbacia do córrego São Joaquim, Pirassununga, 1994

\begin{tabular}{lrr}
\hline Cultura & Área & \% do total \\
\hline Anual & & \\
Algodão & 56,87 & 1,83 \\
Milho & 278,06 & 8,94 \\
Milho safrinha & 5,63 & 0,18 \\
Feijão & 41,14 & 1,32 \\
Arroz & 2,42 & 0,08 \\
Outros & 3,63 & 0,12 \\
Subtotal & 387,75 & 12,47 \\
Perene & 5,80 & 0,19 \\
Abacate & 1,00 & 0,03 \\
Café & 812,95 & 26,14 \\
Cana-de-açúcar & 932,58 & 29,98 \\
Citros & 969,69 & 31,18 \\
Pastagens & $2.722,06$ & 87,53 \\
Subtotal & $3.109,86$ & 100,00 \\
\hline Total & & \\
\hline
\end{tabular}

Fonte: Otani et al. (1996). 
A maioria dos produtores de citros $(88,0 \%)$ se encontra em propriedades menores, em estratos de até 50ha. A soma das áreas de seus pomares ocupa 417,07 ha, e eqüivale a $47,23 \%$ do total da área de citros. O restante da área com citros encontra-se em poucas propriedades dos estratos maiores.

A cana-de-açúcar é cultivada em $29,31 \%$ das propriedades. Na maioria delas $(70,59 \%)$ o cultivo é feito em pequenas áreas, de 0,5 a 10,0 ha, totalizando 33,44 ha ou $4,37 \%$ da área com cana. Como ocorre com os citros, as propriedades maiores (17,85\% do total) cultivam 692,05 ha de cana-de-açúcar, ou seja, $90,41 \%$, quase a totalidade de cana plantada na microbacia.

Tomando-se como base essas informações, pode-se afirmar que os estabelecimentos representativos das atividades agropecuárias na microbacia se encontram nos seguintes estratos de área: a) pastagem: de 0,5 a 10,0ha; b) citros: de 10,1 a 50,0ha; c) cana: de 0,5 a 10,0ha, d) algodão: de 10,1 a 20,0ha.

No que se refere à comercialização dos produtos, o algodão é quase integralmente comercializado na época da colheita, e entregue à indústria de beneficiamento de algodão. Somente dois produtores afirmaram que conseguem armazenar parte do produto para comercializá-lo em época mais oportuna. A cana é, na maioria dos casos, serve de forrageira e é utilizada na própria propriedade; somente a plantada em estratos de área maior de 100,0ha é vendida às usinas da região. A produção de laranja é vendida quase exclusivamente para a indústria. Ocorreu somente um caso, na maior área cultivada, em que a comercialização é feita tanto para a indústria de sucos como diretamente para o mercado de fruta in natura.

Outras informações obtidas por Toledo \& Otani (1992) permitem indicar:

1) Parcial recebimento de assistência técnica. Apenas $57,38 \%$ dos produtores afirmaram receber algum tipo de assistência técnica e, quando precisam de auxilio, recorrem principalmente à rede oficial $(37,70 \%)$ ou às cooperativas $(11,48 \%)$;

2) Contratação de mão-de-obra é realizada principalmente na época da colheita das culturas, sendo a familiar utilizada em $37,70 \%$ das propriedades; 
3) Os produtores que manifestam vontade de mudar ou diversificar a atividade optariam por aumentar a área da laranja, trabalhar com gado de corte e cultivar milho e/ou soja;

4) Muitos produtores manifestaram-se a respeito de dificuldades enfrentadas pela microbacia como um todo: o problema da erosão na microbacia, e da manutenção das estradas, da perda da mata ripária, da falta de escola e de telefone, da necessidade de um armazém comunitário e de um posto de vacinação;

5) Os principais problemas dentro das propriedades referem-se à erosão das terras, tanto pela característica acidentada dos terrenos como pela água proveniente de terras vizinhas; destacam-se também a necessidade de construção elou manutenção de terraços, de canais escoadouros e de açudes.

\subsection{Estrutura do trabalho}

Este trabalho encontra-se estruturado da seguinte maneira: o capítulo II apresenta o quadro referencial básico para este trabalho, contendo uma breve revisão de artigos pertinentes a conceituação de impacto ambiental e a descrição da metodologia utilizada. O capítulo III contém os resultados: inicia pela identificação do impacto ambiental, seguida pelas medidas mitigadoras indicadas para a recuperação ambiental e implantação de um sistema sustentável; em seguida discute-se o resultado da análişe econômica da adoção das medidas mitigadoras e o eventual benefício social para os consumidores de água tratada de Pirassununga. Finalmente, as conclusões proporcionadas pelo estudo e recomendações inerentes ao mesmo são apresentadas no capítulo IV. 


\section{REFERENCIAL TEÓRICO E ANALÍTICO}

Este capítulo descreve a metodologia utilizada para atingir os objetivos propostos no primeiro capítulo, e está organizado em três partes. A primeira, introduz 0 tema mediante breve revisão sobre parte da economia de recursos naturais pertinentes ao estudo, e a seguir define impacto ambiental e apresenta a metodologia empregada para avaliar essa questão com referência à microbacia do córrego São Joaquim. A segunda parte contém os critérios adotados na indicação das mudanças necessárias para eliminar os danos apontados na primeira parte. Finalmente, a terceira parte apresenta o método utilizado nas avaliações econômicas do processo produtivo em uso e do sistema produtivo projetado (com as medidas mitigadoras).

\section{1 - Introdução}

Nas duas últimas décadas, a sociedade tem presenciado o crescimento da conscientização e dos debates sobre as necessidades de recuperação, preservação e racionalização do uso dos recursos naturais. Ao mesmo tempo, o tema tem freqüentado conferências e seminários de um amplo espectro científico e político, referendando a importância de seu caráter multidisciplinar. Todavia, nas abordagens iniciais, procurando atender à demanda social dos movimentos conservacionistas, a comunidade cientifica conseguiu menor amplitude multidisciplinar e, por conseguinte, fez menor uso do instrumental analítico das ciências envolvidas. Mais recentemente, têm surgido estudos com maior abrangência no tratamento científico, onde os temas 
preferidos são a poluição industrial urbana e a devastação das reservas florestais, e os econômicos com enfoque em questões sobre os recursos naturais.

Os estudos sobre conservação de recursos naturais utilizam diferentes abordagens. Por exemplo, pode-se considerar a perda de solo não apenas sob a ótica da depreciação de um fator de produção, mas também como da emissão de resíduos causadores da poluição de rios e lagos, e, como tal, a não conservação do solo assume o caráter de uma deseconomia externa do processo produtivo (ou externalidade negativa).

Segundo Nogueira (1982), "alguns autores têm encarado a questão da consenvação de recursos naturais como um investimento presente a ser confrontado com a perspectiva de um aumento futuro de produto e que, portanto, o problema económico é o de determinar a mais apropriada taxa de desconto da receita futura" (p.385). Sem dúvida, trata-se de uma simplificação exagerada de uma situação muito mais complexa, pois, os autores por ele citados fazem referência a bens e produtos onde o mecanismo de mercado não consegue promover a devida valoração. Estes casos requerem abordagem metodológica específica para permitir uma aproximação do investimento presente.

Outras abordagens podem ser levadas a efeito, como por exemplo o uso de modelos teóricos que equacionam o balanço de matéria física na produção, citado por Desaigues (1990). Seguindo esta abordagem, através da lei da conservação das massas foram construídos modelos que descrevem, em unidades físicas, os fluxos de matéria física através de um sistema econômico. Estes modelos são construídos tendo como base três setores principais: produção, consumo e meio ambiente. $O$ modelo, sendo enriquecido pela agregação de um sistema de preços, permite determinar, entre outros valores, a alocação dos recursos em diferentes usos alternativos.

A análise de insumo-produto, método desenvolvido por Leontief (1970), dá operacionalidade à análise de equilíbrio geral, e também tem sido empregada para avaliar os impactos do desenvolvimento sobre o meio ambiente e sobre os recursos 
naturais. Tem sido aplicada tanto em modelos microeconômicos, como por exemplo, avaliando o consumo de determinado recurso escasso, como também em abordagens macroeconômicas para determinar os possiveis efeitos da aplicação de políticas de preservação do meio ambiente.

Segundo Heady (1950), um dos principais teóricos da linha clássica na economia da conservação do solo, cujos trabalhos foram referência básica durante décadas, "Consenação não é um problema especial em economia. Como nas outras áreas da teoria da produção, o problema está em alocar recursos escassos entre fins altemativos, porém em diferentes periodos de tempo". Nesta linha teórica qualquer análise econômica aplicada à preservação do meio ambiente torna-se uma comparação entre custos e benefícios. Entretanto, a dificuldade na avaliação precisa dos custos e benefícios, da preservação e recuperação de matas e das demais ações voltadas à proteção do meio ambiente, também contribui para o enfraquecimento dos resultados obtidos. Algumas das variáveis, ainda que carregadas de subjetividade, podem ser estimadas, como por exemplo os ganhos de produtividade. Entretanto, outras variáveis são mais "voláteis", como , por exemplo, o valor da segurança obtida pela comunidade ao viver em meios bem conservados, e, portanto, de difícil aferição. Outro parâmetro difícil de medir é o impacto da erosão do solo como agente de poluição das águas, pela sua característica de fonte não pontual de poluição. Todavia, estas estimativas são necessárias para fins de política - caso contrário a política poderá vir a ser mais equivocada.

As primeiras preocupações com os impactos causados pela erosão do solo devido ao uso agrícola foram com relação à perda de nutrientes e fertilidade do solo e as conseqüentes quedas na produtividade e na produção, levando a algumas previsões bastante pessimistas dos especialistas sobre a perda monetária advinda da queda da produção agrícola.

Embora, inegavelmente, a erosão do solo causada pela agricultura leve a perdas, a tecnologia, impulsionada pela maior necessidade de produção decorrente do crescimento populacional, até o momento, tem permitido aumento na produção e na produtividade. Na realidade, a intensidade e o sentido do impacto causado pela 
erosão na capacidade produtiva dos solos tem sido mascarada pelo avanço tecnológico.

Segundo Southgate \& Foster (1996), a erosão do solo passou a ser de interesse público a partir dos anos 30, nos EUA. O USDA (1981), através de simulações para 50 anos, estimou perda de $8 \%$ na produtividade e produção de milho em decorrência da erosão, enquanto que Pierce et al. (1984), considerando as principais características do solo, estimaram, mantendo as condições observadas em 1977, queda de $2 \%$ na produção, após 50 anos. Estimativas da American Agricultural Economics Association (1988) indicaram que a perda da última produção dos EUA seria de US $\$ 40$ milhões, e o valor presente da produção perdida durante o próximo século estaria entre US $\$ 4,3$ bilhões e US\$17 bilhões. Já Larson et al. (1983), calcularam o valor dos nutrientes carregados com a erosão do solo entre US\$0,5 bilhão e US\$1 bilhão ao ano. Para outros paises, onde a erosão é mais problemática, são encontradas estimativas de maior perda. Magrath \& Arens ( 1989) estimaram, para Java, que a erosão custa aos fazendeiros de US\$340 milhões a US\$406 milhões, anualmente.

A partir dos anos 70, a erosão passa a ser preocupante também pelos danos causados aos usuários da água e pelas enchentes. As evidências demonstram que os custos decorrentes do escorrimento de sedimentos e a alta concentração de química são maiores do que as perdas por erosão. Cite-se que nos EUA, $98 \%$ dos sólidos suspensos e $3 / 4$ dos sólidos dissolvidos encontrados nos fluxos de água originaram-se das terras agricolas. Clark et al. (1985) estimaram que a fonte difusa de poluição originária da agricultura custava , anualmente, nos EUA, no mínimo US\$2,2 bilhões (Southgate \& Foster, 1996) ${ }^{1}$. A poluição causada por fonte não pontual, como a agricultura, continuam os autores, é mais dificil de ser localizada do que uma fonte pontual.

A poluição das águas, causada pela agricultura, é um exemplo clássicode extemalidade. A análise econômica das extemalidades concentra-se na

1 Foram estimados em um total de US\$ 3,2 bilhões a US $\$ 13$ bilhões os custos da erosão de solo, considerando as perdas em termos recreacionąis, de facilidades de navegação, uso do fluxo d'água, de prejuizos por enchentes, facilidades no tratamento de água, e outras conveniências proporcionadas pela água. 
ineficiência que aparece quando os individuos ou firmas não consideram os impactos externos de suas atividades. Além disso, um entendimento geral da economia da poluição originária de fonte não pontual também requer análise dos crescentes problemas que ocorrem como quando os usuários da terra não internalizam alguns dos impactos, principalmente ganho de produtividade, advindos do manejo do solo, além de desconsiderarem as conseqüências à jusante, ou ainda, por não serem os proprietários da terra.

Nos EUA, as análises dos impactos da erosão do solo sobre a produtividade não concluem ser aquela o principal problema para o fazendeiro. Entretanto, as pesquisas sugerem que a redução da poluição de fonte não pontual é realizada a baixos custos, o que explica a ampla adoção de redução de cultivo. Dado que são, freqüentemente, marginais òs custos e ganhos de redução da poluição de fontes não pontuais, ênfase maior tem sido colocada nos benefícios à jusante, de se controlar a erosão.

Como fonte poluidora, a agricultura americana implicou, segundo Clark et al. (1985), em: US $\$ 500$ milhões gastos anualmente na dragagem de rios, mais US $\$ 500$ milhões de perda de capacidade de reservatórios e US $\$ 750$ milhões anuais em prejuizos de inundações. Por sua vez, Ribaudo (1986) estimou em nível nacional que cada tonelada métrica de solo deslocado custou para a população a jusante, US $\$ 1,30$ por habitante, com tratamento de água. Forster \& Abraham (1985) usaram um modelo estatístico para estimar o gasto de dragagem do Lago Erie, chegando a US\$1,11 para cada hectare plantado no estado de Ohio. Considerando, além disso, todos os custos a jusante, Abraham (1981) concluiu que a perda socialmente ótima está consideravelmente acima da tolerância de perda de solo (T Value). Por sua vez, Forster et al. (1987), usando modelo estatístico relacionando custos de limpeza de água e resíduos, concluíram que uma redução de $10 \%$ na erosão do solo, em uma bacia hidrográfica do Meio Oeste, permitiria redução de $4 \%$ nos custos de tratamento de água (Southgate \& Foster ,1996). 


\subsection{Impacto ambiental}

Os primeiros estudos sobre Avaliação de Impacto Ambiental (AIA), em projetos brasileiros, foram realizados em meados da década de 70 , calcados basicamente na experiência internacional e por intervenção indireta do exterior, uma vez que procuravam atender a exigências visando a obtenção de recursos financeiros internacionais. Um breve relato dos primórdios do processo de avaliação de impacto ambiental, abrangendo os cenários mundial e nacional, bem como sua devida conceituação, faz-se necessário para uma melhor compreensão da sua incipiente aplicação em análises de atividades do setor agropecuário.

No início dos anos 70, devido a pressões de entidades ambientalistas, 0 Governo dos Estados Unidos criou o "National Environmental Policy Act" (NEPA), o qual instituiu pela primeira vez a AIA. A partir daquele instrumento, toda proposta e/ou ação governamental que pudesse vir a alterar a qualidade do meio ambiente teria que conter declaração detalhada abordando: a) os impactos ambientais; b) os efeitos adversos que não podem ser evitados; c) as alternativas de ação; d) a relação entre os usos dos recursos ambientais a curto prazo e a manutenção e a melhoria de sua produtividade a longo prazo; e) qualquer comprometimento irreversivel ou irrecuperável daqueles recursos, caso a proposta fosse implementada. Conforme Moreira (1989), o documento passou a ser conhecido como "Environmental Impact Statement", ou Declaração de Impacto Ambiental. Este procedimento, rapidamente, passou a ser incorporado nas legislações dos países desenvolvidos, sendo que em alguns, como Canadá e França, concomitantemente baixou-se legislação específica para normalizar a aplicação da AIA.

A postura dos agentes de cooperação econômica, requisitando análises ambientais para viabilizar financiamentos de projetos de desenvolvimento foi, sem dúvida, o principal indutor da difusão da AIA em países em desenvolvimento. Nesta etapa, o Banco Mundial assume papel de destaque, seja no estímulo à adoção política da AIA, como no amparo à necessária capacitação técnica e cientifica para execução 
do documento. Cabe citar também, o Programa das Nações Unidas para o Meio Ambiente - PNUMA (estabelecido em 1972, na Conferência das Nações Unidas sobre - Ambiente Humano, realizada em Estocolmo, na Suécia) como um marco importante para a gestão ambiental em países como Brasil, Venezuela e México.

A necessidade de ajuda financeira internacional para a implementação do Projeto de Barragem e Usina Hidroelétrica de Sobradinho, em 1972, resultou na primeira análise brasileira sobre impacto ambiental. As primeiras avaliações foram realizadas por consultores estrangeiros, e paulatinamente, as equipes passaram a receber especialistas brasileiros e os trabalhos a serem realizados por instituições e empresas nacionais de consultoria.

O Estado do Rio de Janeiro foi, em 1977, pioneiro na regulamentação para uso da AIA, através da instituição do Sistema de Licenciamento de Atividades Poluidoras (SLAP). Este permitiu à então Comissão Estadual de Controle Ambiental requerer, quando necessário, a elaboração do Relatório de Impacto do Meio Ambiente (RIMA). Tal procedimento somente veio a incorporar-se à esfera federal em 1983, com a promulgação do decreto $n^{0} 88.351 / 83$, contendo a Lei de Política Nacional do Meio Ambiente, assim sendo institucionalizada a Avaliação de Impacto Ambiental como um dos instrumentos para a execução da política ambiental no País. O decreto estabelece também, os critérios e o conteúdo mínimo do estudo de impacto ambiental, denominando-o de Relatório de Impacto no Meio Ambiente (RIMA), e tornando-o acessivel ao público.

Segundo Moreira (1989), "o processo do AIA apresenta duas vertentes: a) técnico-científica, com os estudos de impacto propriamente ditos (métodos, técnicas, pesquisas, dados e previsões); e, b) político-institucional, que diz respeito aos procedimentos administrativos e ao aparato legal e burocrático que os regulam". Fundamentalmente de natureza interdisciplinar, o AIA compreende não somente a abordagem dos diversos fatores que compõem o meio ambiente tanto físicos ou biológicos (ar, água, solo, etc), como também aqueles referentes aos valores sociais e de qualidade de vida (saúde, educação, patrimônio cultural e histórico, etc), contemplando ainda as possiveis inter-relações entre estes fatores. 
Um documento genérico de avaliação de impacto ambiental é a formalização de uma série de procedimentos que garantem uma análise sistemática dos impactos ambientais do projeto. Seus resultados procuram assegurar meios para a tomada de decisão quanto à execução do projeto, contendo inclusive medidas mitigadoras para controle dos possiveis efeitos ambientais.

Como principais informações de uma AIA genérico de determinado projeto, pode-se listar: a) delimitação e diagnóstico ambiental da área de atuação; b)identificação dos impactos significativos; c) estimativa da magnitude e da importância dos mesmos; d) identificação dos impactos de possiveis alternativas para o projeto; e) identificação das medidas mitigadoras para controle dos impactos detectados; f) programa de monitoramento dos impactos. Estes resultados se destinam às entidades governamentais, a grupos de defesa do meio ambiente, à classe política e ao público em geral; sem dúvida é este caráter democrático que torna o AIA um dos principais instrumentos políticos do gerenciamento ambiental.

\subsection{Avaliação de Impacto Ambiental (AIA)}

Uma alteração em determinada área de meio ambiente freqüentemente tem sido denominada de impacto, efeito ou mesmo dano ambiental. Todavia, como alerta Wathern (1988), alguns autores têm defendido uma diferenciação entre efeitos, mudanças no meio biofísico por motivos naturais ou induzidas pelo homem, e impactos, como as conseqüências das mudanças. Aceitando a definição de Wathern, "um impacto contém tanto componentes espaciais como temporais e, pode ser descrito como a mudança constatada em um parâmetro ambiental (para determinado periodo de tempo e área especíica) decorrente de uma ação particular, quando este parâmetro é comparado com valores em uma situação onde supõe-se que a ação não tenha ocomido". 
No presente estudo, o impacto ambiental é fruto do uso inadequado dos recursos naturais contidos na microbacia, sendo portanto medido em uma situação "ex-post", ao passo que de acordo com a definição tem-se a mensuração em uma situação "ex-ante".

Nos estudos ambientais pioneiros, ou AlA's como normalmente são chamados, os instrumentos analíticos desenvolvidos e aplicados referem-se a agressões ambientais derivadas da atividade urbana e/ou industrial, impactos propulsores iniciais da conscientização ambientalista. Nestes casos, o tipo de dano causado é, quase sempre, bastante tangivel e de menor abrangência espacial, fatores estes determinantes ao estímulo para movimentos governamentais e/ou nãogovernamentais com vistas ao devido controle (Wathern, 1988).

Para exemplificar, analise-se a poluição de ar devido às atividades de determinada empresa: boa parte dessas emissões de residuos pode ser identificada com relativa facilidade pelas pessoas ao seu redor; além disso, o impacto é mais localizado, viabilizando o ativismo e a mobilização dos afetados pela observância de seus direitos. No outro extremo, pode-se estimar as dificuldades em organizar adequadamente a população do Estado e obter um resultado conclusivo na luta pela preservação do remanescente paulista da Mata Atlântica.

Genericamente, o tema a ser tratado neste trabalho estaria mais próximo deste último exemplo, por se tratar de impacto de poluição elou assoreamento causado em calhas e barragens de macrobacias. Todavia, conforme relatado em 1.1 , a turbidez das águas do córrego São Joaquim está dificultando o processo de captação pela Empresa Municipal de Saneamento e, portanto, pode-se reduzir, inicialmente, a questão à instância de Pirassununga.

Da mesma forma como existem diferentes definições para impacto ambiental, há também diversos tipos de abordagens dessa temática. Segundo Sanchez (1989), pode-se ter ao menos duas visões distintas: a abordagem exaustiva e a dirigida. A primeira pressupõe, como quesito básico para uma avaliação de melhor qualidade, a apresentação de grande volume de informações com alto grau de 
especificidade. Segundo Beanlands \& Duinker (1984), ela é pouco aceita, pois o excesso de informações pode prejudicar a qualidade do estudo, requerendo maior prazo para execução e tornando-o extremamente caro. A segunda abordagem, mais voltada à tomada de decisões, tem suas necessidades de pesquisa fixadas em função do objetivo da AIA (gerenciamento, escolha de alternativa, e outros) e portanto, procura elucidar pontos bem definidos a respeito dos impactos.

Este estudo está pautado na abordagem dirigida, centrando a avaliação de impacto ambiental na erosão do solo e nas modificações hidrológicas da microbacia, sob a ótica das interações e inter-relações decorrentes dos processos produtivos agropecuários desenvolvidos nas propriedades.

O uso indiscriminado do sistema original de recursos naturais, com certeza, ocasionou redução (tanto em número como em espécies) na flora e fauna locais. Porém, não fazem parte do escopo deste trabalho, a mensuração e a valoração de tal impacto ambiental. As dificuldades de sua devida valoração, somadas aos objetivos específicos deste estudo induzem a não contabilizar os custos ambientais das reduções na flora e fauna, na expectativa da obtenção de resultados mais consistentes em relação à questão da conservação do solo. Por outro lado, a adequação do uso do solo e a recuperação da mata ripária irão promover alguma ampliação biológica no ecossistema; este benefício também não será avaliado, sendo aceito como uma externalidade positiva do projeto.

O escopo deste trabalho é analisar os impactos das inadequações do uso do solo pelas explorações agropecuárias para diferentes unidades produtivas em uma microbacia hidrográfica. Trata-se de avaliar projetos de readequação no uso do solo, para controle da erosão e suas conseqüências, em termos de resultados na produção e renda para o produtor rural e, para a qualidade da água, rio abaixo, após o emprego das medidas mitigadoras. 


\subsubsection{Método de avaliação}

Especificamente, a AIA na microbacia do córrego São Joaquim foi organizada da seguinte maneira: a) identificação dos impactos; b) seleção das questões relevantes ("scoping"); c) estudo de base para obter parâmetros para a quantificação; d) avaliação dos impactos propriamente dita.

A identificação de impactos foi obtida mediante detalhada e criteriosa observação visual do local, entrevistas na área de estudo a proprietários e residentes, e coleta de informações em órgãos governamentais e privados.

A etapa seguinte consistiu da seleção dos impactos mais relevantes ou "scoping"2. Em função da consulta prévia à comunidade da microbacia , e intervenção da Prefeitura Municipal, como já citado em 1.3., projetou-se como questão mais relevante, a erosão hídrica cujo impacto põe em risco todo o complexo de recursos naturais e limita, em muito, o uso do solo 3 .

A terceira etapa referiu-se aos estudos de base para obtenção dos parâmetros utilizados na avaliação dos impactos. Em essência, constituiu-se no estudo básico sobre a degradação do solo. Neste estudo, a ferramenta analítica básica é a Equação Universal de Perda de Solo (Universal Soil Loss Equation-USLE), de Wischmeier \& Smith (1978). Esta equação permite estimar a perda de solo, por unidade de área, resultante da erosão causada pela chuva:

$$
A=R \times K \times L \times S \times C \times P
$$

\footnotetext{
${ }^{2}$ Segundo Beanlands, este termo surgiu no cenário de avaliações de impacto em meio ambiente como um resultado da regulamentação formulada pelo Governo Americano em 1979, a qual serviu como base para as regulamentações de vários outros países. Essa metodologia proporcionou maior objetividade aos estudos, tornando-os também mais acessiveis à crítica pelo público, função precipua e fundamental das avaliações de impacto ambiental.

3 Por exemplo, entre os residentes na microbacia do córrego são Joaquim, o problema mais citado foi a má condição de tráfego das estradas vicinais.
} 
onde:
$\mathrm{A}=$ perda de solo por unidade de área, em t/ha;
$\mathbf{R}=$ fator erosividade, índice sobre 0 poder erosivo das chuvas, em MJ.mm / ha. $h^{4}$;

$K=$ fator erodibilidade, índice sobre a suscetibilịdade do solo à erosão, em t.h / MJ.mm;

$$
\begin{aligned}
& L=\text { fator comprimento da vertente, (adimensional); } \\
& S \text { = fator declividade da vertente, (adimensional); } \\
& C \text { = fator uso e manejo do solo, (adimensional); } \\
& P \text { = fator práticas conservacionistas, (adimensional). }
\end{aligned}
$$

Essa expressão, utilizada por Donzell et al. (1992) e Menck (1993), "tem sido aplicada por diversos autores em estudos de médio-grande porte" (IPT, 1986). Dos parâmetros que a compõe, C e P são fatores tecnológicos universais, e que podem ser alterados pela adoção de práticas adequadas de manejo de solo. Já o fator $\mathbf{R}$ é condicionado pelo clima, sendo portanto, específico para a região. Os parâmetros $\mathbf{K}, \mathbf{L}$ e $\mathbf{S}$ variam de acordo com cada tipo de solo.

O fator $\mathbf{R}$ expressa o poder erosivo do impacto da chuva. Assim sendo, é determinado segundo o regime pluviométrico do local de estudo. É estimado conforme metodologia aplicada por Bertoni \& Lombardi Neto (1990) onde obtêm-se o valor anual pela agregação de estimativas baseadas em médias pluviométricas mensais.

A susceptibilidade do solo à ação erosiva da chuva, indicada através do fator K, refletem certas propriedades do solo. Estas implicam em características como

\footnotetext{
${ }^{4}$ Megajoule $(M J)=$ unidade de trabalho ou energia.
} 
velocidade de infiltração, permeabilidade, capacidade de retenção de água e de resistência ao transporte pela chuva.

Os fatores L e S, na prática são estimados conjuntamente, compondo o chamado fator topográfico. Sua determinação, segundo Bertoni \& Lombardi Neto (1990), é dada por:

$$
L S=0,00984 \times C^{0,63} \times D^{1,18}
$$

onde:

$$
\begin{aligned}
& C=\text { comprimento do declive, em m; } \\
& D=\text { grau do declive, em } \% .
\end{aligned}
$$

O fator C reflete o comportamento do solo frente ao uso e manejo, modificando-se durante as várias fases do ciclo agrícola, pois, em cada uma delas a exposição à erosão difere. Os fatores que mais influenciam em $\mathbf{C}$ são: preparo do solo, restos de cultura, rotação de culturas e estande. Neste estudo, os valores são indicações de especialista em conservação do solo.

O fator práticas conservacionistas $\mathbf{P}$, estabelece a relação entre as perdas de solo quando adotada uma prática conservacionista e as perdas em um cultivo acompanhando o sentido do declive ("morro abaixo").

Finalmente, obtido os valores de perda de solo por área, faz-se a confrontação com níveis de tolerância máxima, encontrados em Lombardi Neto e Bertoni (1975). Às matrizes de exigência de fatores de cada cultura, e para cada tipo de solo, incorpora-se aquelas decorrentes das ações necessárias para levar a perda estimada aos limites acima mencionados.

Uma vez de posse dos valores acima mencionados, será processada a avaliação do processo erosivo, que conterá as estimativas das perdas físicas médias ocorridas no ecossistema da microbacia do córrego São Joaquim, pela não 
observância de técnicas de manejo e cultivo do solo, nos processos agropecuários lá desenvolvidos.

\subsubsection{Valoração do impacto ambiental}

O ato de valorar o dano causado a um recurso natural de uso comum, é uma tarefa extremamente difícil e controvertida. Muitos dos bens e serviços providos por um sistema ambiental, como beleza cênica e valor biológico, não têm seu real valor determinado pelo mecanismo de oferta e procura, constituindo-se nas chamadas "imperfeições de mercado". No entanto, como a legislação federal prevê a possibilidade de atribuir pena àqueles que vierem a lesar o patrimônio público ambiental, o Ministério Público tem se valido de instituições e especialistas para a elaboração de laudos e perícias envolvendo a valoração de impactos ambientais.

Para esta atividade, torna-se imprescindivel a posse da avaliação física dos danos, ou seja, a obtenção de parâmetros físicos que quantifiquem o impacto ambiental, tornando viável uma estimạtiva da avaliação monetária dos danos. $O$ dano monetário é definido por Comune (1995) como "a soma monetária que os indivíduos recebem, necessária para compensar uma alteração do meio ambiente". O autor classifica as perdas que compõe a avaliação do dano monetário em dois tipos: financeiras e intangíveis. As primeiras, também caracterizadas por "custos diretos", representam as modificações do nivel de despesas em conseqüência da mudança na qualidade do meio ambiente e, com maior ou menor grau de dificuldade, são passíveis de mensuração. As segundas, também denominadas por "custos indiretos", englobam um conjunto de diversas perdas abstratas, custos sociais e psicológicos, e invariavelmente, apresentam extrema dificuldade para avaliação.

O conceito de valor econômico total, segundo Pearce et al. (1990), reconhece a taxonomia de valores econômicos relacionados ao ambiente natural. Quando existe mercado para recurso natural e/ou o seu serviço, o valor de uso é 
através do preço, mais facilmente, reconhecido. A este devem se somar outros valores, estimados para a sua conservação, quer seja para uso posterior, ou apenas para preservação. Assim o Valor Econômico Total (VET) pode ser expresso como:

$$
V E T=V U D+V U I+V O+V P+V E
$$

onde:

VUD = valor de uso direto, que apresenta o valor do recurso natural em seus mercados específicos, como madeira, turismo, educação, moradia, pesquisa;

$\mathrm{VUI}=$ valor de uso indireto, que tenta exprimir o que se pode obter com a presença do recurso, com sua função ecológica, a qual não é transacionada no mercado. No caso de uma floresta, seria o valor de sua capacidade de reciclagem de nutrientes, e o de proteção à bacia hidrográfica e o microclima.

VO = valor de opção, definido como uma espécie de prêmio pelo risco da incerteza quanto ao futuro do bem ou do serviço ambiental que ele presta. Enquanto o valor de uso refere-se ao valor do atual mercado, o valor de opção é dado pela geração atual para o mercado futuro.

$\mathrm{VP}=$ valor potencial, definido como 0 valor que exprime o significado econômico do bem para as próximas gerações, sendo a quantia que os indivíduos estão dispostos a pagar para legar o potencial de uso do bem às próximas gerações, seja de valor de uso ou não para seus descendentes.

VE = valor de existência. $E$ o valor do recurso em si dado pelos indivíduos tanto para a atual geração como para as futuras, independentemente de serem usuários ou beneficiários imediatos do bem em questão.

Em abordagem semelhante no aspecto da valoração, Smith (1993) sugere que, como a procura sobre informações de valor tem crescido mais rapidamente que o avanço sobre o conhecimento de novos métodos, o próximo passo 
que se faz necessário é a definição de uma série de características que permita tratar os serviços do meio ambiente como uma espécie de "commodity".

Importante contribuição sobre o tema pode também ser encontrada em Dixon \& Sherman (1990), onde, a exemplo de Randall (1987), os autores aplicam ao consumo dos chamados "bens públicos" os conceitos de não-exclusividade, nãorivalidade e de congestionabilidade, e apresentam as várias possibilidades de medir custos e benefícios advindos da proteção e/ou recuperação de áreas ambientais. Para o caso específico de proteção de bacias hidrográficas, apontam as características de não-exclusividade, de não-rivalidade e de produção de efeitos externos para os benefícios de controle de erosão, regularização da vazão e prevenção de enchentes. A extensão dos benefícios dependerá das características do terreno, do solo, da proteção atual existente, das alternativas de uso e do tipo de investimento e uso da terra a jusante.

Para um projeto de proteção ambiental, de maneira similar a qualquer outro, a tomada dé decisão usualmente é baseada na avaliação econômica dos níveis de expectativa dos benefícios e custos para um determinado horizonte de tempo. $\mathrm{Na}$ mensuração dos custos de um projeto para proteção de áreas são considerados os custos diretos (os desembolsos monetários), indiretos (danos indiretamente causados pela existência da área preservada) e de oportunidade (benefícios perdidos com a proteção). No entanto, na valoração dos benefícios do projeto de proteção têm surgido mais dificuldades. Alguns métodos têm sido utilizados para dar valores monetários em muitos destes benefícios. Entre as técnicas baseadas em valores de mercado, é usual a abordagem da mudança na produtividade, em decorrência da não proteção. Por exemplo, as alterações nas produtividades de culturas agropecuárias ou no poder hidrelétrico em consequêencia da erosão do solo, ou a valorização de produtos florestais, além da madeira da floresta, advinda da própria proteção do ecosistema. Outra variante é a abordagem das perdas de ganhos, que avalia a perda de produtividade do homem derivada da piora das condições ambientais.

Quando os benefícios não podem ser avaliados no mercado, são utilizados alguns indicadores, como os valores de mercado para bens similares, que 
sinalizem o benefício. Por exemplo, o valor de uma propriedade ou da terra pode indicar os atributos do ecossistema nạ qual está inserida. Da mesma forma o valor do salário para determinado serviço pode assinalar os riscos associados à sua execução. Outra alternativa utilizada para avaliar os benefícios de áreas preservadas é a abordagem do custo da viagem para usufruir de suas qualidades/ amenidades. A partir daqueles valores estima-se a curva de demanda, que permitirá avaliar o excedente do consumidor, o quanto o consumidor estará disposto a pagar.

No caso de impossibilidade de usar uma "proxy", dada a dificuldade de tradução de valor monetário para certos efeitos, ou da inexistência de bens substitutos, as abordagens podem ser através de entrevista direta. A partir das respostas, determina-se o valor do bem para o agente econômico e, então, faz-se extrapolações para determinar o valor agregado para todos os afetados. As principais técnicas para obtenção dessas aproximações baseiam-se em medidas do excedente do consumidor: a variação compensatória e a variação equivalente, isso é, o quanto o consumidor deverá receber pela perda de amenidades ou o quanto estará disposto a pagar para recebê-la. É chamado de método contigencial.

Outra forma de avaliar os beneficios de proteção é através dós custos de transformação da área natural em produtiva. As técnicas são: a análise do custo de oportunidade; a análise de eficiência de custo, onde se escolhe a alternativa de menor custo para o alcance de determinada meta (máximo nivel de erosão, por exemplo), e a análise das diferenças nos gastos atuais e potenciais.

Uma vez que este trabalho trata de uma avaliação ex-post optou-se dentre as técnicas para valoração ambiental, pela abordagem do custo da reparação ou do custo das atividades mitigadoras ("mitigation-cost approach"), admitindo-a mais adequada aos objetivos. Esta técnica examina qual seria o custo para reverter o dano causado através de mudanças no uso da terra ou da implementação de um projeto de desenvolvimento. Requer a estimativa do custo das operações e do material necessário às ações técnicas para conter os efeitos da mudança em relação ao estágio anterior. 


\subsection{REFERENCIAL TEÓRICO}

Os recursos naturais possuem várias características que dificultam a abordagem dos problemas econômicos a eles relacionados, segundo a teoria de equilíbrio de mercados. $\mathrm{Na}$ economia de mercados, o ponto ótimo de alocação de recursos, se dá no momento onde produção e mercados não mais podem ser reorganizados para aumentar a satisfação (utilidade) de determinado indivíduo(s) sem diminuir a satisfação de outro(s). Para a solução "ótima de Pareto", também chamada de first-best solution, são condições necessárias a existência de preços eficientes, a ausência de custos de transações que impeçam as trocas e direitos de propriedades não atenuados. Muitas vezes, por suas características, em se tratando de recursos naturais, tal solução não é possivel de ser atingida.

Como principal entrave tem-se que muitos recursos naturais não são negociáveis e, portanto, não têm um mercado onde possa se formar seu preço: nesse caso, diz-se que ocorre uma imperfeição de mercado. Esta pode estar associada à uma característica de "não-exclusividade" no consumo de um recurso, decorrente de uma atenuação nos direitos de propriedade (não se formará mercado para um produto que não se sabe a quem pertence).

A existência de externalidades não compensadas também leva a uma ineficiência, ou falha de mercado. Quando atividades individuais ou em grupo fornecem benefícios (que não sejam pagos) ou impõe custos (que não sejam compensados) a outros individuos ou grupos, não ligados àquela atividade produtiva, ocorre a externalidade positiva ou negativa. Estas constituem-se em importantes fontes de ineficiência de mercado.

Quando não é possivel se atingir o ótimo econômico, recorre-se à uma solução baseada em um ótimo técnico, caracterizando a chamada "second-best solution", como neste estudo, onde a ądequação ambiental ótima se apoia nas classes de capacidade de uso. 


\subsubsection{Direitos de propriedade}

Os modelos analíticos para equilíbrio geral requerem direitos de propriedade que não imponham restrị̧ões aos movimentos de mercado de tal sorte que os mecanismos de preços possam vir a ser suficientes para conduzir a alocação dos recursos aos respectivos usos de valor máximo. Todavia, nem sempre os direitos de propriedade acham-se convenientemente delineados e presentes em uma economia.

O direito de propriedade sobre um bem consiste no direito de usá-lo, de mudar sua forma e de transferir parte ou a totalidade dos direitos sobre esse bem. $O$ direito de propriedade privado sobre algum bem é identificado quando apenas determinada(s) pessoa(s) possui(em) autoridade de decisão sobre sua utilização. No entanto, esse poder de decisão pode ser restringido por regras (de comportamento social, familiar ou religioso) ou mesmo pela legislação, quando o Estado interfere no direito de propriedade, "atenuando-o". É o que ocorre, por exemplo, com as matas ciliares, áreas de preservação permanente, segundo a legislação vigente.

Segundo Randall (1987), as características desejáveis em um aparato de direitos de propriedades não atenuados, devem ser:

a) a completa especificação dos direitos, a ponto de servir como um perfeito referencial sobre os direitos inerentes à posse, bem como das restrições que os acompanham e das sanções ou penalidades resultantes de possiveis violações;

b) a exclusividade, de maneira a que os custos sociais e privados sejam iguais. Implica que os benefícios e custos pela posse sejam internalizados;

c) a possibilidade de transferência, para assegurar total possibilidade de transações, permitindo a obtenção das igualdades marginais; e

d) a garantia, para se tornar efetivo. 
Quando a estrutura de direitos é adequada, permite o desenvolvimento de mercados, estes tenderão a estabelecer preços estimulantes à conservação, produção e à distribuição de bens entre os consumidores. Estes preços deverão, também, demonstrar constantemente a escassez relativa dos bens. Assim sendo, sem interferência, os mercados promovem uma eficiente alocação de recursos e distribuição de bens, de uma forma onde a eficiência lastreia-se nas livres decisões dos agentes econômicos envolvidos.

Todavia, na prática, quando ocorre uma transação entre agentes econômicos, estes têm de recorrer a uma série de informações de forma a garantir maior "eficiência" à negociação, podendo-se citar entre outros: informações para estabelecer posição e estratégia no processo de diálogo; os custos implícitos à própria troca; custos judiciais ou de procedimentos necessários para garantir o cumprimento do acordo (elaboração e validação de contratos). Tais despesas vêm a compor os chamados "custos de transação". A existência de custos positivos de transação, rompendo um dos pressupostos para o alcance do "ótimo de Pareto", abre a possibilidade para que soluções administradas possam vir a substituir, em certos casos, o mercado como caminho ideal para solucionar conflitos de consumo.

Ainda segundo Randall (1987), nos casos onde ocorrem as imperfeições de mercado, ou "falhas de mercado" como alguns economistas as têm denominado, os sinais gerados pelo livre mercado são ineficientes. Estas falhas estão relacionadas com situações de atenuação de direitos de propriedade e/ou particularidades da natureza física dos bens envolvidos. Estes problemas se traduzem através da formação de preços desajustados, e portanto ineficientes, fornecendo sinais errados e transmitindo ao sistema econômico estímulos inadequados.

A análise dos direitos de propriedade tem se tornado importante instrumento para a economia dos recursos naturais, ambas estando entrelaçadas desde 1954, segundo Gordon (1954). O paradigma dos direitos de propriedade persiste sendo importante para estudos de recursos naturais, dado que os direitos de sua posse tendem a ser substancialmente diferentes do padrão típico de propriedade numa economia de mercado. A dificuldade em se estimar o valor de um recurso 
natural está associada à atenuação de direitos de propriedade. Porém, de fato, a maior parte dos recursos naturais não é exclusivamente pública ou privada. Muitas vezes, um recurso natural pode ser de propriedade privada e com exploração regulamentada pelo governo; nestes casos, ocorre um gerenciamento misto, público e privado. 0 acesso ao recurso não é livre, e, a decisão sobre o seu uso é tomada por vários indivíduos ou entidades com diferentes direitos sobre o mesmo.

Dois avanços na teoria dos direitos de propriedade conseguiram reduzir a dificuldade de valoração de recursos naturais: o primeiro é o conceito de propriedade comum, onde há distribuição dos direitos de propriedade dos recursos, cujos proprietários tornam-se co-iguais em seus direitos de uso. Ao limitar o acesso ao recurso, a dissipação de valor associada à falta de direitos de propriedade pode ser suficientemente minimizada. Outro refere-se ao compartilhamento da propriedade do recurso natural conforme a utilização de seus atributos, permitindo às diferentes partes interessadas o controle a diferentes atributos do recurso. Com essas interpretações, tornou-se mais clara a operacionalidade da exploração de alguns recursos naturais, cujas definições distribuem-se entre os extremos de livre acesso total e puramente privado. Por exemplo, no caso de áreas privadas com certa abundância de animais selvagens, onde os proprietários controlam o direito ao acesso mas o governo pode regulamentar a caça e/ou outros usós. No paradigma dos direitos de propriedade, muitas ações são consideradas soluções "second best"(Lueck, 1995).

\subsubsection{Externalidades}

As imperfeições de mercado costumam estar presentes em análises econômicas envolvendo recursos naturais ou problemas ambientais. São situações de não-rivalidade no consumo, de não-exclusividade na posse de determinados bens, ou da geração de efeitos externos (não devidamente compensados) durante produção e/ou consumo de bens, também conhecidas como externalidades. Quando as 
externalidades estão presentes, o resultado de um mercado competitivo não é provavelmente eficiente de Pareto. Para Pigou (1928) , quando as forças de mercado falham em compensar esses efeitos externos, uma intervenção governamental tornase necessária, a fim de que o agente, que os causou, internalize o custo em sua decisão. Ou seja, a externalidade deve ser corrigida através da ação do Estado. Os críticos, no entanto, apontam a impossibilidade do cálculo da taxa correta que resultaria em eficiência alocativa (Dahlman, 1979). Ainda assim, geralmente, são elaborados sistemas de tributos e subsídios objetivando levar uma economia de mercado para uma alocação ótima de Pareto. Assim, economias de mercado, que já subsidiaram fortemente um modelo de produção agrícola com fortes impactos ambientais, vem atualmente subsidiando a recuperação de matas e práticas de conservação do solo como meio de facilitar investimentos ambientais.

Segundo Southgate \& Forster (1996), para controlar as externalidades, o uso de tributação dos impactos da poluição por fonte não pontual é rara fora dos EUA, embora seja alta a magnitude dos gastos associados à sedimentação e qualidade da água nas bacias hidrográficas.

A taxação tem sido a mais reconhecida forma de controle da poluição. Entretanto, muitas vezes é difícil obter-se uma taxa eficiente para determinado tipo de poluição. Para ser eficiente, o valor da taxa deve levar o controle para o ponto onde a demanda por redução à poluição se iguale à "oferta de poluição" no nível desejado. A taxa deve elevar o custo de produzir, forçando uma retração na quantidade produzida e conduzindo a emissão de poluentes ao patamar desejado.

Sempre é difícil a avaliação dos custos causados pela erosão a jusante. De maneira geral há consciência de que as erosões e seus desdobramentos são problemas para toda a sociedade e não apenas para a agricultura. Assim, regulamentação para controle de poluição, arrecadação de taxas sobre poluidores, programas de educação-pesquisa, e, subsídios são mecanismos diretos que os 
governos usam para controlar a poluição sem origem pontual ${ }^{5}$, muito embora, outras políticas governamentais possam estar afetando diretamente os niveis de poluição.

Dados os altos custos administrativos da regulamentação e de taxas, a política norte-americana de conservação de solo enfatizou os subsídios (ou compartilhou os custos) e a assistência técnica. Poucos se mostraram satisfeitos com o compartilhamento dos custos. Como Ribaudo (1986) aponta, escolhas sobre alocação de fundos limitados para o subsídio à conservação do solo são influenciadas pela importância relativa dos impactos sobre o rendimento e poluição de fontes não pontuais. Assim, o programa de compartilhar os custos tem sido mais de transferência de renda do que de conservação do solo. Os EUA tem grande parte dos esforços na conservação de solo e no controle de poluição de fontes não pontuais, baseados na pesquisa e educação, em trabalho conjunto com extensionistas. Outra abordagem é a de providenciar claros incentivos econômicos para os fazendeiros reduzirem erosão de solo por meio de taxas ou subsídios. Finalmente, se for o caso, um arranjo na propriedade da terra deve ser feito para permitir que os fazendeiros recebam, a longo prazo, os benefícios do controle de erosão (Southgate \& Forster, 1996).

Entre os autores que estudaram os problemas advindos de externalidades, Coase (1960) ocupa um papel relevante com sua contribuição ao ressaltar o papel da estrutura de direitos de propriedade na resolução de conflitos por ela causados. O teorema de Coase coloca que, dada uma situação de direitos de propriedades não atenuados, negociações entre as partes eliminarão as externalidades Pareto-relevantes, resultando em solução eficiente. Além disso a alocação de recursos será independente da especificação inicial dos direitos de propriedade. Assim, desconsiderados os custos de transação, e, desde que os direitos não sejam atenuados, a solução pode ocorrer mediante negociação entre as partes

No entanto, apenas a explicitação legal dos direitos de propriedade não garante o alcance do ótimo de Pareto. Ao se considerar a hipótese mais realista da existência de custos de transação positivos (limitação de conhecimentos, informações

5 Em Paute do Equador, Southgate \& Macke (1989) estimaram que o manejo da bacia hidrográfica poderia render de US $\$ 15$ a US $\$ 40$ milhões de benefícios (em termos de Valor Presente) durante a vida do projeto. 
assimétricas, ou oportunismo dos agentes econômicos), chega-se à conclusão da necessidade de interferência do governo para apressar e melhorar os resultados, em contraposição à dependência da negociação expontânea entre as partes. Ressalte-se o efeito significativo de custos de transação positivos ao reduzirem as margens e o valor real dos pagamentos.

A argumentação de Randall indica que o resultado final poderá depender dos direitos, e baseia-se no fato de que a especificação desses direitos implicará em restrição orçamentária para as partes envolvidas. Se oferta e demanda por redução de extemalidades forem afetadas pelas restrições orçamentarias dos participantes, ocorrerão efeitos-renda que serão suficientes para promover deslocamentos nas curvas.

$\mathrm{Na}$ realidade, mesmo com direitos de propriedade não atenuados, podem existir diferentes alocações ótimas de recursos, conforme o grau de especificação daqueles direitos ${ }^{6}$. Assim, não existe uma única solução de eficiência, mas sim a solução conforme a especificação inicial de renda, saúde e direitos legais. Portanto, para Randall, a alocação de recursos depende das especificações iniciais dos direitos de propriedade.

Em resumo, segundo Randall, sob regra de ausência de responsabilidade (com direitos de propriedades não devidamente especificados e/ou não praticáveis), custos de transações positivos provocam queda na demanda por redução de externalidades (deslocando-a para a esquerda), determinando um ponto de equilibrio com menor redução da mesma. Quando sob responsabilidade plena, os custos de transação deslocam a oferta de redução para a direita (pelo menor valor pago) tomando a redução mais barata.

Aplicando-se estas conclusões a esta análise, teremos em situação de responsabilidade nula, quando os prejudicados pelo uso inadequado da terras da microbacia năo têm o direito de serem ressarcidos pelo dano ambiental e como os

Gum exemplo de especificação com atenuação de direito seria a liberdade para poluir até um determinado patamar de emissão. 
custos de transação associados sạ̃o elevados (muitas pessoas envolvidas) a demanda por redução da externalidade pode se retrair ao ponto de não se conseguir nenhuma redução. Por outro lado, os causadores de poluição não sofrem qualquer espécie de estímulo para reduzirem a emissão de poluentes, pois não são cobrados pelos custos de reparação. Todavia, uma vez explicitados estes custos, e como a comunidade de poluidores pode ser contatada pelo poder executivo local sem grandes custos de transação, é possivel iniciar uma negociação para pleitear a transferência de responsabilidade, de forma que os prejudicados venham a ter o direito e os mecanismos para exercê-la, e provocar condições para redução na externalidade.

Assim, além da utilização de impostos e subsidios, outra alternativa apontada para a redução dos problemas derivados das externalidades é um sistema legal que assegure direitos de propriedade bem definidos, abrindo caminho para negociações e o equilíbrio desejadp̀. Porém, não é seguro que os problemas ambientais possam ser solucionados apenas com a negociação entre as partes, pois a alocação de recursos resultante do acardo pode não levar à eficiência máxima.

\subsection{Análise custo-beneficio (ACB)}

O critério de Pareto pressupõe que o "bem-estar" não é máximo quando é possivel melhorar a condição de um indivíduo sem piorar a de outro. Assim, a condição necessária para o máximo do "bem-estar" é que seja impossível alterar a forma pela qual a sociedade usa seus recursos para melhorar a situação de alguém sem piorar a de outro.

Os projetos enfocando conservação ambiental são desenvolvidos considerando os aspectos técnicos, institucionais, organizacionais, comerciais, financeiros, gerenciais econômicos e sociais (culturais e políticos). Desta forma, uma análise estritamente econômica de um projeto de conservação baseia-se na 
pressuposição de que os demais aspectos foram adequadamente considerados no estágio de preparação do projeto.

A análise custo-benefício é um instrumento usado para avaliação de projetos. Pode também ser entendida em alguns casos como um método de avaliação social quando produz informações para direcionar a alocação de recursos escassos entre projetos alternativos, objetivando maximizar o benefício líquido para um expressivo segmento social. A fundamentação teórica da análise custo-benefício se traduz na valoração de determinado bem ou serviço pelo consumidor através de sua disposição a pagar por um aumento ("willingness to pay - WTP") ou de aceitar uma redução ("willingness to accept - WTA"), caso a variação medida venha a ser positiva ou negativa. Assim, tomando-se como base que a utilidade do bem é no mínimo igual ao preço pago pelo mesmo, o consumidor ao lhe atribuir um valor (WTP) superior ao preço, gera então um "lucro" líquido; esse valor, obtido pela disposição a pagar (WTP) menos o atual pagamento, é o excedente do consumidor.

Na prática, a ACB apresenta-se como uma análise de impactos seguida das respectivas avaliações; uma confrontação entre o valor presente do fluxo de benefícios e do valor presente de todos os investimentos e custos decorrentes. Evidentemente, essa análise de impaçtos deve incorporar os efeitos diretos e indiretos, as externalidades, e salientar os aspectos intangíveis, como o ganho em qualidade de vida pelo aumento na disponibilidade de flora e fauna silvestres.

Estes componentes foram organizados de forma a melhor adequar a ACB aos objetivos deste estudo, e explorar toda a potencialidade do modelo; como conseqüência, a análise e os resultados produzidos tornam-se mais explícitos. A esse respeito, associa-se a importante distinção entre os conceitos de avaliação social e de avaliação privada de um projeto.

Um projeto pode ser avaliado sob diferentes óticas: a do empresário, a do agente financeiro, a do governo, a de outros empresários (concorrentes ou não), e a de outros segmentos sociais. A análise social tende a sofrer severas críticas, como lembra Contador (1988), pelas aproximações e imprecisões nos cálculos dos preços 
sociais e na apreciação das externalidades. Os preços sociais, a rigor, deveriam ser determinados em um modelo de equilibrio geral, o que, em realidade, determina o preço-sombra. Por outro lado, o preço social é obtido entre o custo social dos fatores e o preço vigente no mercado. Segundo Contador, costuma-se, erroneamente usar preço social e preço-sombra como sinônimos

Conforme expõe o autor, preços de mercado são, por definição, encontrados no dia a dia, e podem ser diferentes para o mesmo bem (por estratégia de vendas, custos de transportes, ou outro fator) e, portanto, costuma-se usar a média de várias informações. Já os preços sociais não são observados diretamente e representam o custo de oportunidade dos bens para a economia como um todo.

Alguns autores consideram três tipos de análises: a econômica, que utiliza preços de mercado perfeito (se o mercado assim o fosse) para avaliar o projeto; a financeira (privada), faz uso dos preços de mercado; e a social, que usa preçossombra e avalia os impactos sobre a distribuição de renda. Kuyvenhoven \& Mennes, citados por Graaff (1993), entendem como uma aproximação da análise social a de custo-beneficio social, pois uma vez comparada a esta última, vê-se que também verifica os custos e benefícios sociais, sem contudo avaliá-los quanto a distribuição entre os vários segmentos da sociedade. Nesta análise, conforme Gittinger (1972), taxas e subsídios são tratados como transferências de pagamentos, ou seja, variáveis macroeconômicas. Por outro lado, na análise financeira, as mesmas variáveis são tratadas do ponto de vista microeconômico como custos (taxas) e receitas (subsídios), embora a análise seja realizada sob o ponto de vista de um financiamento para o projeto como um todo.

Através da análise financeira pode-se apurar o retorno do capital investido pelos diferentes participantes e produzir outros resultados como "o aumento da renda líquida das propriedades" e "capacidade de pagamento". Estes Ihe conferem o importante carácter de indicador sobre a viabilidade de implementação de projetos pois, "não nos parece bom ter um projeto rentável do ponto de vista de toda a sociedade, mas onde os proprietárips não conseguem, através do mesmo, obter ganhos para sua sobrevivência" (Gittinger, 1972). Embora este estudo não contemple 
a avaliação social propriamente dita, procurou-se explicitar esta questão, muito bem colocada pelo autor, através de duas abordagens: uma considerando a microbacia como um todo; e outra, analisando cada unidade produtiva individualmente.

Entretanto, algumas dificuldades e/ou pontos susceptiveis à critica costumam ser apontadas com relação ao método em apreço. Em estudos na área do meio ambiente, as maiores dificuldades da aplicação da $A C B$ residem na correta valoração dos componentes da análise. Quando o mecanismo de mercado não é eficiente para estabelecer um preço realista para certos componentes, alguns métodos alternativos podem ser usados para estimar os respectivos custos de oportunidade ou preços-sombra, geralmente para valores de danos ambientais e/ou externalidades. Todavia, no caso de efeitos menos tangiveis, como beleza cênica, patrimônio histórico e outros, a quantificação monetária pode não ser adequadamente alcançada.

Do ponto de vista do embasamento teórico, alerta Helmers (1979), citado em Graaff (1993), o princípio da marginalidade que lastreia a otimização de Pareto pode ser afetado por imperfeições de mercado ou por ociosidade estrutural de fatores. Desta forma, as decisões de investimento indicadas podem não ser apropriadas, requerendo portanto, ajustes nos fluxos econômicos a serem usados na ACB. Outro ponto levantado relaciona-se aos pagamentos compensatórios de certos bens entre ganhadores e perdedores, quando o bem em questão envolve problemas de intangibilidade, e o respectivo valor de troca não pode ser traduzido monetariamente (critério de Kaldor-Hicks).

Também pode ser citada a dificuldade na escolha correta da taxa de desconto, refletindo adequadamente a preferência intertemporal da sociedade, assunto discutido por Pearce et al. (1990). Esses autores também se referem ao horizonte do projeto, ao analisarem aspectos relativos à transferência intertemporal e intergerações de "ativos" do meio ambiente, mediante a manutenção do estoque de capital natural do sistema ecológico estudado. Todavia, apesar de apresentar vários pontos passiveis de crítica, suas vantagens permitem à $A C B$ continuar sendo um método largamente utilizado e principal ferramenta para análise de projetos. Entre as principais pode-se citar: é uma técnica que reduz tudo a uma unidade comum (valor 
monetário), facilitando a análise e a apresentação dos resultados; não difere de outros métodos quanto à requisição de dạdos; $e$, não é rigidamente limitada à análise financeira, podendo ser estendida, ao incorporar custos sociais (externalidades) para permitir avaliações de projetos sobre o meio ambiente, por entidades governamentais.

A análise de custo-benefício, neste estudo usa o valor presente líquido como método de comparação entre os projetos que contemplam, em essência, dois modelos de utilização do solo. Esse método apresenta a vantagem de permitir o uso de taxa de desconto e também explicitar os montantes monetários inerentes aos projetos.

Com referência à taxa de desconto a ser utilizada, esta deveria expressar a taxa de juros de mercado ou a produtividade marginal do capital (custo de oportunidade). Uma taxa "social" de desconto poderia ser aplicada caso esta refletisse a preferência intertemporal da sociedade; mas esse é um parâmetro difícil de ser determinado. Por conta deste fato, conforme Graaff (1993), uma série de taxas (6, 9 e 12\%) têm sido aplicadas a trabalhos envolvendo avaliação de meio ambiente.

Em uma análise custo-benefício, quando aplica-se o critério convencional de decisão - taxa de retorno igual à produtividade marginal do capital, os projetos de conservação e/ou recuperação tendem a apresentar baixos retornos, uma vez que os custos ocorrem no curto prazo e os benefícios no longo prazo. Assim sendo, a discussão de como internalizar o fator ambiental em projetos de manejo de recursos naturais passa a se concentrar em possiveis formas de promover ajustes na taxa de desconto. Sobre este tema, Pearce et al. (1990) apresentam uma ampla discussão, e ponderam que nas economias mais simples as duas tendem a convergir, porém, na economia real as duas taxas divergem, com o custo de oportunidade do capital sendo, muitas vezes superior à taxa de juros; nessas condições não há concordância geral na determinação da taxa de juros a ser empregada. Enfatizando a dificuldade aliada à alta subjetividade do tema, alertam que altas taxas tendem a encorajar a devastação de recursos naturais, podendo deslocar os custos para as próximas gerações. As taxas altas, mais freqüentes em países menos desenvolvidos, são a causa de muita degradação com a opção dos indivíduos por medidas de curto 
prazo às expensas de práticas sustentáveis. Em sua análise mostram que se por um lado os argumentos baseados na utilidade de consumo possam sugerir o uso de baixas taxas de desconto, de outro lado os argumentos lastreados no custo de oportunidade apontam para altas taxas de desconto. Os autores, apesar de explorarem o tema sob vários enfoques distintos, e de sugerirem algumas formas de ajuste na taxa de desconto, ponderam sobre a excessiva controvérsia do mesmo e apontam para o uso de critérios convencionais nas análises de projetos ambientais. Citam que o Banco Mundial usa para paises com pouco capital, onde a taxa tende a ser alta, valores em torno de $10 \%$ para decidir seus empréstimos àqueles países.

Abordagens mais comumente utilizadas buscam ampliar a análise de custo-benefício, através da incorporação dos custos das externalidades, dos valores extra-mercado (valor de opção e de existência), baixas taxas de desconto e imposição de limites de segurança mínima (incorporando fatores risco e incerteza). De Janvry, Sadoulet \& Santos (1993) apresentam uma contribuição ao sugerirem a introdução de análises em dois pontos no tempo: um sob ponto de vista da geração atual e o outro, sob ponto de vista da futura geração. Desta forma, os autores entendem que consigase submeter 0 projeto ao princípio do desenvolvimento sustentado: "O desenvolvimento que encontra as necessidades atuais sem comprometer a habilidade das futuras gerações de encontrar suas próprias necessidades" (Comissão Brundtland - ONU, 1987). A análise se dá através da distinção entre horizontes distintos, um para cada geração. Tal procedimento foi por eles utilizados ao avaliarem projeto de desenvolvimento sustentável, onde aplicam uma defasagem de 20 anos em fluxos distintos para cálculo do valor presente líquido como forma de avaliar os custos do projeto, tanto para a presente geração como para a futura.

Segue-se então a explicitação formulada por Randall (1987), de como avaliar as mudanças em um sistema de meio ambiente decorrentes de um impacto ou de um projeto de recuperação. Considere-se o sistema ecológico (E) a ser estudado, produtor de uma série de bens e serviços, representados pelo vetor $\underline{\mathbf{S}}=\mathbf{s}_{1}, \ldots, \mathbf{s}_{\mathrm{m}}$, reconhecidos e valorizados pela comunidade. Esses serviços podem ser: água, beleza cênica, alimentos, recreação, enfim, bens e serviços que dão suporte à vida humana, 
à flora e à fauna, participantes do sistema. O fluxo de serviços, em determinado período de tempo $\underline{t}$, resulta das características ou atributos definidos pelo vetor $\underline{A}=\left(a_{1}\right.$, ..., $\left.a_{s}\right)$, do meio ambiente. Podem ser expressos pelas funções:

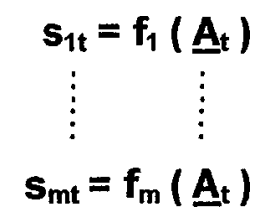

Entretanto os atributos de $\mathrm{E}$ podem ser alterados tanto pela ação antrópica (remoção da cobertura vegetal do solo para uso específico e outras), como pela própria natureza (ocorrências climáticas, biológicas e outras). Portanto, os atributos são funções desses insumos naturais $\underline{\mathbf{N}}$ e insumos resultantes de atividades controlados pelo homem $\underline{\mathbf{X}}$. Assim, o vetor atributo pode ser representado pelas funções:

$$
\begin{gathered}
\mathbf{a}_{1 \mathrm{t}}=\mathbf{g}_{1}\left(\underline{\mathbf{N}}_{\mathrm{t}}, \underline{\mathbf{X}}_{\mathrm{t}}\right) \\
\vdots \\
\vdots \\
\mathbf{a}_{\mathrm{st}}=\mathbf{g}_{\mathrm{s}}\left(\underline{\mathbf{N}}_{\mathrm{t}}, \underline{\mathbf{X}}_{\mathrm{t}}\right)
\end{gathered}
$$

onde $\underline{\underline{N}}_{\mathrm{f}}$ e $\underline{\boldsymbol{X}}_{t}$ são vetores de insumos.

Ambos estão sujeitos a escassez $\mathrm{e}$ às respectivas funções de produção dependendo, portanto, das leis da natureza e da tecnologia. Para que a oferta de serviços do sistema $E$ possa estar completamente configurada resta considerar que a demanda por determinados serviços $\mathbf{S}_{\mathbf{k}}$ influencia o nível de $\underline{\mathrm{X}}$ e que interações entre $\underline{\mathrm{X}}$ e $\underline{N}$, são possíveis. 
Ao considerar-se o valor dos serviços de recursos direta e indiretamente oferecidos (ou produzidos) pelo sistema E, pode-se exprimir a quantidade de serviços demandada pelo indivíduo j, em determinado período de tempo t, como:

$$
U_{\mathrm{jt}}=U_{\mathrm{jt}}\left[\underline{\underline{S}}_{\mathrm{jt}}^{\mathrm{a}}, \underline{\mathbf{Z}}_{\mathrm{jt}}^{\mathrm{j}}\left(\underline{\underline{S}}_{\mathrm{jt}}^{\mathrm{b}}\right), \underline{Z}_{\mathrm{jt}}^{\mathrm{a}}\right]
$$

onde:

$\underline{\mathbf{S}}^{\mathbf{a}}$ representa o vetor dos serviços diretamente ofertados pelo sistema ambiental considerado;

$\underline{\mathbf{S}}^{\mathbf{b}}$ representa o vetor dos serviços usados na produção dos bens expressos pelo vetor $\underline{Z}^{\text {b: }}$ e,

$\underline{Z}^{\mathrm{a}}$ representa o vetor dos bens produzidos independentemente de $\underline{\mathbf{S}}$.

Admitindo-se que a curva de oferta $\underline{\mathbf{S}}_{\mathrm{jt}}$ dos serviços ambientais demandados por um indivíduo da comunidade, possa ser obtida pela minimização dos gastos sujeitos à restrição da manutenção da utilidade, pode-se estimar $\underline{\boldsymbol{V}}_{\mathrm{j}}\left(\boldsymbol{S}_{\mathrm{j}}\right)$, valor

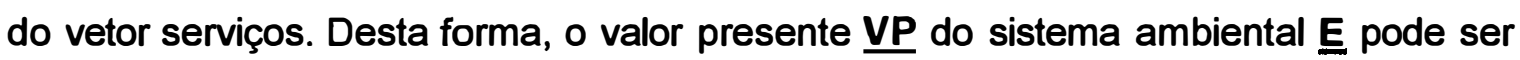
obtido pela somatória do fluxo líquido do valor dos serviços, descontados à determinada taxa $\mathbf{r}$, no período de tempo $\mathbf{t}$, como se segue:

$$
\operatorname{VP}(E)=\sum_{i} \sum_{j} V_{j t}\left(S_{j t}\right) /(1+r)^{t}
$$

Como já definido anteriormente, o sistema $\mathrm{E}$ fornece uma série de bens e serviços em função de $\mathbf{N}$ suas características e/ou atributos (estoque de capital natural), e de $\mathbf{X}$ vetor de alterações antrópicas. Assim sendo, um projeto ou impacto ambiental por ação antrópica pode ser definido como uma mudança de um sistema ambiental $E$ para um outro sistema $E^{D}$ como conseqüência da alteração de $\underline{X}$ para $\underline{X}^{D}$. 
Aceita a colocação acima, toma-se viável estimar o valor presente líquido da implantação do projeto (D) de recuperação ambiental da microbacia do córrego do São Joaquim comparando-se os valores presentes do fluxo de serviços da microbacia com e sem projeto da seguinte forma:

$$
\operatorname{VP}(D)=\operatorname{VP}\left[\left(E^{D}-C^{D}\right)-E\right]=\left\{\Sigma_{t}\left[V_{t}\left(\underline{S}_{t}^{D}\right)-C^{D}{ }_{t}-V_{t}\left(S_{t}\right)\right]\right\} /(1+r)^{t}
$$

onde:

$$
C_{t}^{D}=S_{t} C_{t}^{D} /(1+r)^{t}
$$

corresponde ao valor presente da somatória dos custo do projeto de transformar em $E^{D}, e$

$$
\begin{gathered}
V_{t}\left(S_{t}^{D}\right)=S_{j} V_{j t}\left(\underline{S}_{j t}^{D}\right) \\
e \\
V\left(\underline{S}_{t}\right)=S_{j} V_{j t}\left(\underline{S}_{\mathrm{ft}}\right)
\end{gathered}
$$

são respectivamente, os valores presentes dos fluxos de serviços do sistema com e sem o projeto.

Nesse caso, se VP > 0 , o projeto, segundo Randall, passaria pelo filtro da análise custo-benefício e,portanto,considerado como uma possibilidade de mudança para um ponto "Pareto-relevante" onde, após as devidas compensações (resolvidas as questões de extemalidades), alguém apresentaria ganhos enquanto que ninguém sofreria perdas. 


\subsection{Estimativa do beneficio}

\subsubsection{O excedente do consumidor}

Uma forma de medir os benefício sociais da aplicação de um projeto baseia-se no conceito de "excedente do consumidor", definido como a diferença entre o efetivamente pago pelo produto e o valor máximo que o consumidor estaria disposto a pagar para ter uma quantidade adicional versus a alternativa de não têla (Contador, 1988, p.83)” (Figura 2).

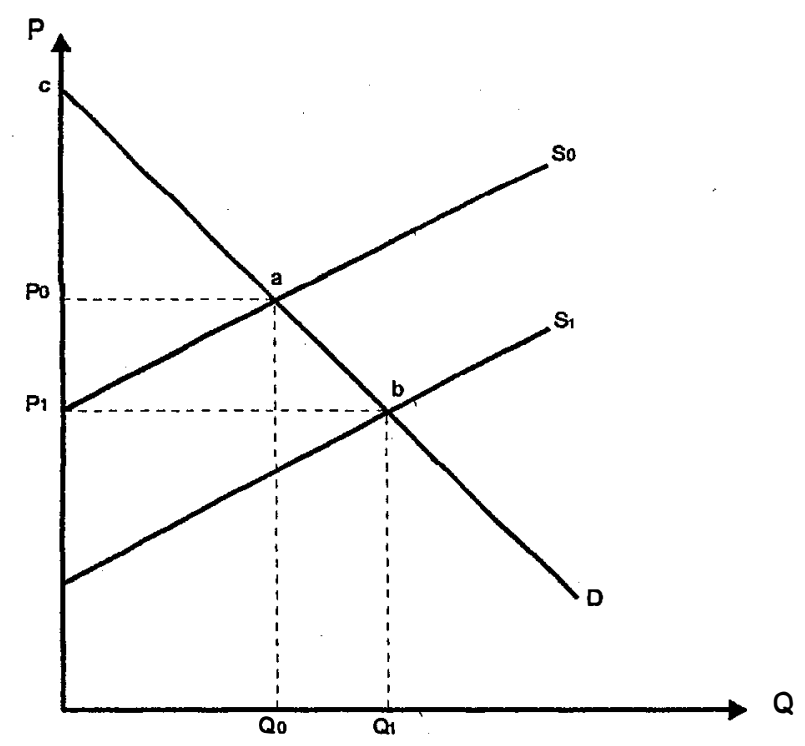

Figura 2. Mensuração do excedente do consumidor.

Seja a situação inicial de equilíbrio onde a demanda $\mathbf{D}$ e a oferta inicial $\mathbf{S}_{\mathbf{0}}$ de água determinando a quantidade $\mathbf{Q}_{\mathbf{0}}$ consumida ao preço $\mathbf{P}_{\mathbf{0}}$. $\mathbf{A}$ ampliação da oferta deslocando a curva de oferta para $\boldsymbol{S}_{1}$, à direita, determinando um novo ponto de equilíbrio com o preço caindo de $\mathbf{P}_{\mathbf{0}}$ para a $\mathbf{P}_{\mathbf{1}}$, e maior quantidade consumida, $\mathbf{Q}_{\mathbf{1}}$. 
Inicialmente, o excedente do consumidor era representado pela área $P_{0} a c$, e, com o novo ponto de equilibrio, passa a ser representado pela área $P_{1} b c$. Desta maneira, a variação positiva do excedente do consumidor pode ser medida pela diferença entre as áreas:

$$
P_{1} b c-P_{0} a c=P_{1} b_{a} P_{0}
$$

Com demanda e oferta lineares e pressupondo-se um deslocamento paralelo desta última (apenas para simplificação das expressões algébricas, pois não há impedimentos para que seja convergente ou divergente), a quantificação da variação do excedente econômico dos consumidores ( $\triangle E C$ ) pode ser assim formulada:

$$
\Delta E C=\left(P_{0} Q_{1}-P_{1} Q_{0}+P_{0} Q_{0}-P_{1} Q_{1}\right) / 2
$$

Varian (1994) argumenta que "tendo-se estimativas das curvas de demanda e oferta de mercado de um bem, em princípio, não seria difícil calcular as perdas no excedente dos consumidores devidas a variações nas politicas do governo... e isso pode representar informação útil para julgar métodos de tributação; contudo, sofre de dois defeitos: primeiro, o cálculo do excedente do consumidor só é válido para preferências que podem ser representadas por funções de utilidade quaselineares e que estas são aproximações razoáveis para bens pouco afetados por efeitos-renda. Segundo, o cálculo dessa perda considera todos os consumidores e produtores, gerando assim uma estimativa do "custo" de uma política social para um 
consumidor representativo "mítico" e seria desejável saber quem suporta os custos" (p.283).

O conceito de excedente do consumidor ganha forte expressão através de Marshall, ao desenvolver sua teoria da demanda, em concordância com a teoria marginal da utilidade. Todavia o autor, reconhecendo a limitação representada pelo fato de que, na análise, a utilidade marginal da moeda é mantida constante, sugere a restrição de que o conceito de excedente deva ser aplicado à bens com pequena expressão na despesa total do consumidor. Posteriormente, Hicks (1958), baseandose em curvas de indiferença, redefine o excedente do consumidor e conclui que caso $o$ efeito renda seja pequeno, ter-se-ia uma boa medida através do conceito de Marshall para o excedente do consumidor.

Conforme proposto por Contador (1988), ao aplicar-se o conceito de elasticidade-preço da demanda ao cálculo da área interessada (representada pelo trapézio $\mathbf{P}_{0} \mathbf{a b} \mathbf{P}_{\mathbf{1}}$ ), é possível dar maior operacionalidade à forma de estimar $\mathbf{0}$ excedente do consumidor. Sendo $|\eta|$ a elasticidade-preço da demanda, temos nas proximidades do ponto a:

$$
|\eta|=\left(\Delta Q / Q_{0}\right) /\left(\Delta P / P_{0}\right)
$$

Por definição, o valor corrente de mercado de determinado produto $\left(V_{0}\right)$, o montante correspondente ao seu preço $P_{0}$, vezes a quantidade $Q_{0}$, pode-se, com alguma manipulação algébrica demonstrar que a estimativa da variação do excedente do consumidor pode ser obtida pela expressão:

$$
\Delta W_{b}=(1 / \eta) V_{0}(\Delta Q / Q) \cdot[1+(1 / 2) \cdot(\Delta Q / Q)]
$$

Esse foi o método utilizado nesse estudo. De acordo com Contador, para obter-se uma estimativa da variação do excedente do consumidor de água devese conhecer três parâmetros: $V_{0},(\Delta Q / Q)$ e $\eta$. $O$ primeiro, $V_{0}$, foi colhido junto ao 
Serviço de Águas e Esgoto de Pirassununga (SAEP); o segundo, $(\triangle Q / Q)$, é a variação de volume de água que pode ser obtida com as medidas mitigadoras a serem adotadas na microbacia em estudo; $\boldsymbol{e}$ a terceira, $\boldsymbol{\eta}$, obteve-se através do ajustamento de uma funçăo de demanda a dados sobre consumo de água tratada, fornecidos pela SAEP para o período de janeiro de 1988 a outubro de 1996.

\subsubsection{A especificação do modelo de demanda por água tratada}

A especificação do modelo de demanda por água tratada pela população de Pirassununga procurou seguir a teoria do comportamento do consumidor, ou seja:

$$
Q=f(P, R, P o)
$$

onde a quantidade de água consumida $\mathbf{Q}$ é função do seu preço $\mathbf{P}$, da renda $\mathbf{R}$ e da população Po. Os preços dos bens substitutos não são considerados pelo fato de não existirem substitutos próximos para a água.

Uma das maiores dificuldades na especificação do modelo de demanda por água reside no fato de o consumidor, quando decide consumir determinada quantidade de água, defrontar não apenas com um preço por unidade mas também com uma tabela de preços crescentes em blocos ${ }^{7}$ à medida que o consumo aumenta, como mostra a Figura 3

Conforme a figura, os volumes consumidos Q1(12m3) e Q2(23m3) corresponderiam aos valores cobrados de $R \$ 14,00$ e $R \$ 42,00$, respectivamente.

\footnotetext{
${ }^{7}$ Até há pouco tempo atrás, a mesma política era adotada para a eletricidade no Brasil; hoje, o consumidor se defronta com apenas um preço por unidade na sua decisão de consumo da eletricidade. Em outros paises, os preços cobrados tanto pela água quanto pela eletricidade se apresentam tanto em blocos de preços crescentes como decrescentes, como em.vários estados norte-americanos
} 


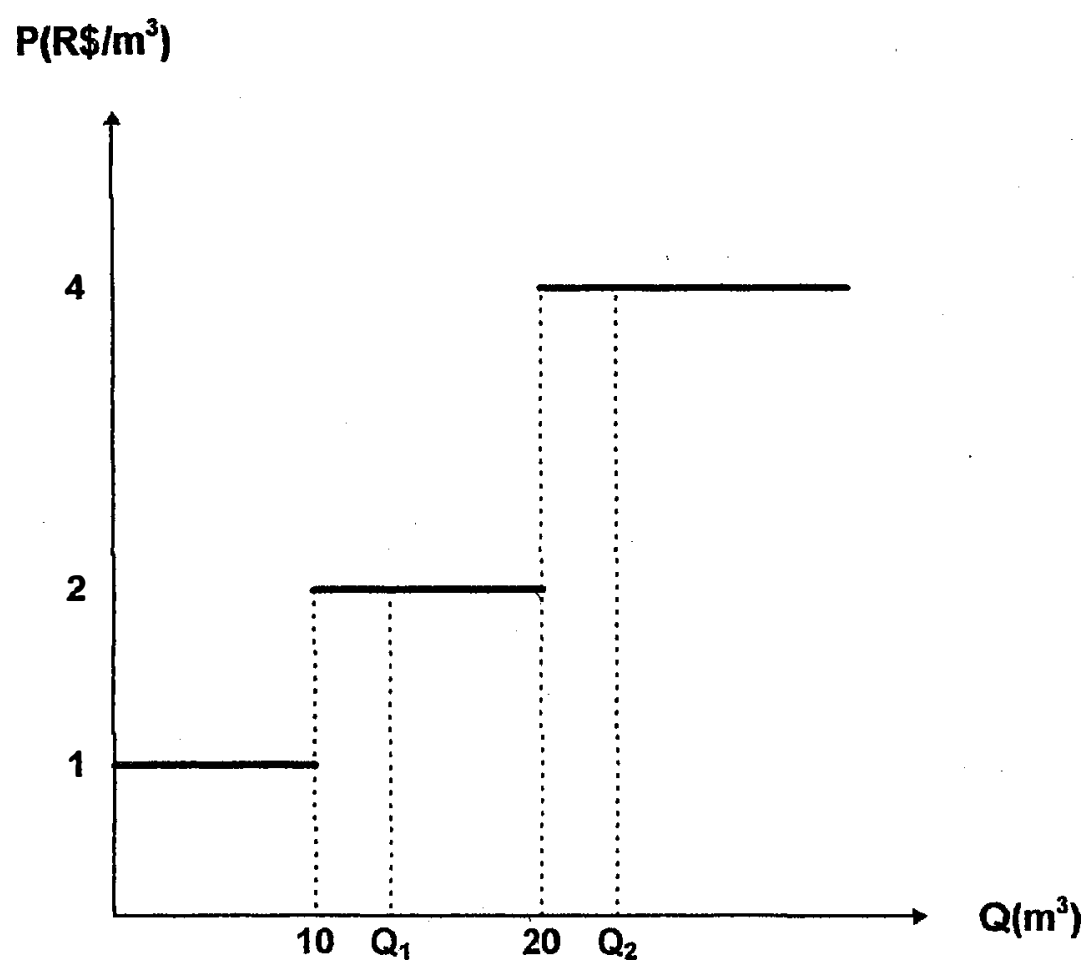

Figura 3. Tabela de preços crescentes em blocos.

Para representar o preço com o qual o consumidor se defronta, os primeiros estudos sobre demanda por água consideraram o preço médio, ou seja, o preço correspondente à quantidade média consumida ou o obtido pelo valor do dispêndio total dividido pela quantidade consumida (Wong, 1972; Young, 1973; Foster \& Beattie, 1979). Muitas críticas surgiram na literatura com respeito a esse procedimento, fazendo com que, nos modelos estimados, o preço médio fosse substituído pelo preço marginal, de maior conformidade com a teoria econômica (Howe \& Linaweaver, 1967 e Berry \& Bonem, 1974). Nesses modelos, o preço marginal considerado foi sempre o preço cobrado pela última unidade consumida de água.

Em seu famoso artigo sobre demanda por eletricidade, Taylor (1975) chamou a atenção sobre o fato da utilização de um único preço marginal (PMa) ignorar o efeito-renda de mudanças nos preços intramarginais. Segundo ele, não somente um preço, mas toda a tabela de preços é relevante para a decisão do consumidor. Assim, 
Taylor introduziu uma medida de preço intramarginal como variável independente na estimativa de demanda por eletricidade, além do PMa. Ele sugeriu que a mesma poderia ser definida como o preço médio intramarginal (valor dos gastos do consumidor com eletricidade até o último bloco de preço exclusive, dividido pela quantidade consumida até o último bloco exclusive) ou pelo valor dos gastos do consumidor até o último bloco de preço exclusive.

Num comentário sobre o estudo de Taylor, Nordin (1976) mostrou que as variáveis corretas a serem consideradas eram o preço marginal (cobrado pela última unidade consumida) e a renda real depois de levar em conta os preços intramarginais. Essa última foi definida pela diferença entre o que o consumidor efetivamente paga pela quantidade total consumida até o último bloco exclusive e o que ele teria de pagar por essa mesma quantidade se o preço marginal fosse cobrado por todas as unidades consumidas.

Nos casos onde tem-se uma tabela de preços crescentes em blocos, essa diferença é interpretada pelo consumidor como um "subsídio" recebido no consumo, até o último bloco exclusive. Por outro lado; se os preços são decrescentes, a diferença é encarada como um "imposto".

Billings \& Agthe (1980) mostraram que o modelo de Nordin estava correto não somente para tabelas de preços decrescentes, mas também para as de preços crescentes.

O modelo de demanda por água estimado para o município de Pirassununga seguiu a especificação do modelo de Nordin, no que diz respeito às variáveis relacionadas ao preço.

Além das variáveis relacionadas ao preço, foram também considerados determinantes da demanda por água em Pirassununga, a renda e o número de residentes por ligação de água encanada. Essa última representa a importância do tamanho da família no consumo de água, à semelhança dos estudos conduzidos por Howe \& Linaweaver (1967) e Morgan (1973). 


\subsubsection{A forma funcional do modelo de demanda por água tratada}

A forma funcional usada para estimar a demanda urbana por água tratada no município de Pirassununga foi a linear, cuja função pode ser representada por:

$$
Q=a_{0}+a_{1} P+a_{2} D+a_{3} R+a_{4} P O+u
$$

onde:

$$
\mathbf{Q}=\text { quantidade de água consumida por ligação }{ }^{8}, \mathrm{em}^{3} \text {; }
$$

$\mathbf{P}=$ preço marginal da água, correspondente ao preço cobrado no último bloco de consumo, em reais por $\mathrm{m}^{3}$;

$\mathbf{D}=$ diferença entre a quantia que o consumidor efetivamente pagou pela água por ele consumida e a quantia que esta pagaria caso o consumo dele lhe fosse cobrado ao preço marginal por todas as unidades consumidas. Esta variável assume valor negativo, em reais;

$$
\begin{aligned}
& \mathbf{R}=\text { renda por ligação, em reais; } \\
& \mathbf{P o}=\text { número de pessoas por ligação }{ }^{9}, \mathrm{e} \\
& \mathbf{u}=\text { erro da regressão. }
\end{aligned}
$$

\footnotetext{
${ }^{8}$ As ligações de água se referem aos pontos de distribuição em residências e em edifícios de apartamentos, públicos, comerciais e industriais. Não foi possível separar por categoria de residentes, como seria desejável.

${ }^{9}$ Foster e Beattie (1979) usaram essa variável independente.
} 


\subsubsection{Fonte dos dados}

De acordo com o exposto acima, espera-se que o consumo de água tratada, por ligação, tenha como principais determinantes o PMa por $\mathrm{m}^{3}$ de água, 0 valor da diferença como definido por Nordin (1976), o tamanho e a renda da "household" (essas últimas representadas pelas ligações). As seguintes fontes foram utilizadas para coletar dados representativos de cada uma dessas variáveis:

O Serviço de Água e Esgoto de Pirassununga - forneceu as tabelas de preços correntes, os volumes mensais de água consumida e o número de ligações de água encanada, para cada mês do periodo de janeiro de 1988 a outubro de 1996.

Fundação do Sistema Estadual de Análise de Dados (SEADE) forneceu dados de população urbana e renda do município de Pirassununga para o período da análise. 


\section{RESULTADOS}

Este capitulo apresenta os resultados, organizados em três partes principais. Na primeira descreve-se o impacto ambiental causado pelas atividades agropecuárias desenvolvidas na área em estudo, bem como as sugestões técnicas indicadas por especialistas para minimizar os danos ambientais. Em seguida é realizada análise verificando a viabilidade econômica da adoção das medidas mitigadoras propostas. Ao final, a questão abordada refere-se aos benefícios sociais da adoção dessas medidas.

\subsection{0 impacto ambiental}

A avaliação descrita a seguir, resulta de levantamento de campo, pesquisa e análise bibliográfica, e entrevistas com técnicos especialistas em conservação do solo e fotointerpretação.

A microbacia do córrego São Joaquim é constituída por um relevo de morrotes alongados e espigões, definição de Carneiro et al. (1981), válida para as partes de cabeceira, uma vez que a jusante, o relevo passa a apresentar-se mais em forma de colinas. Com altitude aproximadamente variando entre $600 \mathrm{~m}$ e $850 \mathrm{~m}$ e um comprimento superior a 10km, apresenta, segundo Stein et al. (1992), assimetria nos vales. As vertentes voltadas para o sul são mais curtas, íngremes e com rupturas pronunciadas, enquanto as voltadas para o norte são mais alongadas, de perfil mais contínuo e quase com ausência de rupturaș. De maneira geral, o padrão de drenagem é dendrídica cuja densidade, fornecida pela relação entre área total drenada e o comprimento da rede de drenagem, define-se como média. 
A área delimitada pela microbacia do córrego São Joaquim e seus afluentes, ribeirões Duas Barras e Salto Grande, foi desmatada no início do século para o plantio de café. Conforme relato de morador local, obtido por Stein et al. (1992), "... o desmatamento e o plantio de café provocaram entulhamento da concavidade de cabeceira por materiais trazidos pela enxurrada. ... . Sobram cerca de $3 m$ de material coluvionar arenoso e avermelhado soterrando solos e troncos que estavam à superfície há oitenta - noventa anos ". Sem dúvida, o desmatamento generalizado, desfigurando a paisagem original, deve ter produzido, como conseqüência, algum desequilíbrio ambiental, pois a redução da flora deve ter contribuído e acelerado a diminuição de parte da fauna silvestre.

Embora o objeto deste estudo seja o atual uso inadequado do solo em atividades agropecuárias, vários são seus efeitos sobre o meio ambiente, como por exemplo a perda em biodiversidade pelo comprometimento de espécies. Todavia, torna-se imperativo ressaltar os efeitos imediatos da mudança na cobertura vegetal sobre o processo de erosão hídrica.

O impacto ambiental causado pelo uso do solo sem respeitar suas características e, que pode, em muitos casos, não permitir a manutenção de uma agricultura permanente e sustentável, apresenta-se de diversas maneiras. Como já mencionada, a retirada da cobertura florestal reflete-se, de imediato, em excessivo transporte de sedimentos pelas enxurradas, material este oriundo das camadas mais superficiais do solo. Com isso, o solo perde importantes propriedades físico-quimicas e, conseqüentemente, parte de sua capacidade produtiva. Com o passar do tempo, sulcos e até voçorocas começam a surgir, evidenciando um processo erosivo descontrolado (Figuras 4 e 5). Ocarrem assoreamentos de cursos d'água e há sensivel perda de produtividade, uma vez que os fertilizantes não conseguem recuperar as importantes propriedades físicas e químicas perdidas junto com a camada superficial do solo. No caso da microbacia do córrego São Joaquim, tem-se como agravantes os fatos de o desmatamento ter ocorrido por volta do início do século $\mathrm{XX}$, dando lugar a um cultivo de café quando havia com pouca ou nenhuma preocupação com o controle da erosão. Ao café, seguiu-se um ciclo de ocupação com 


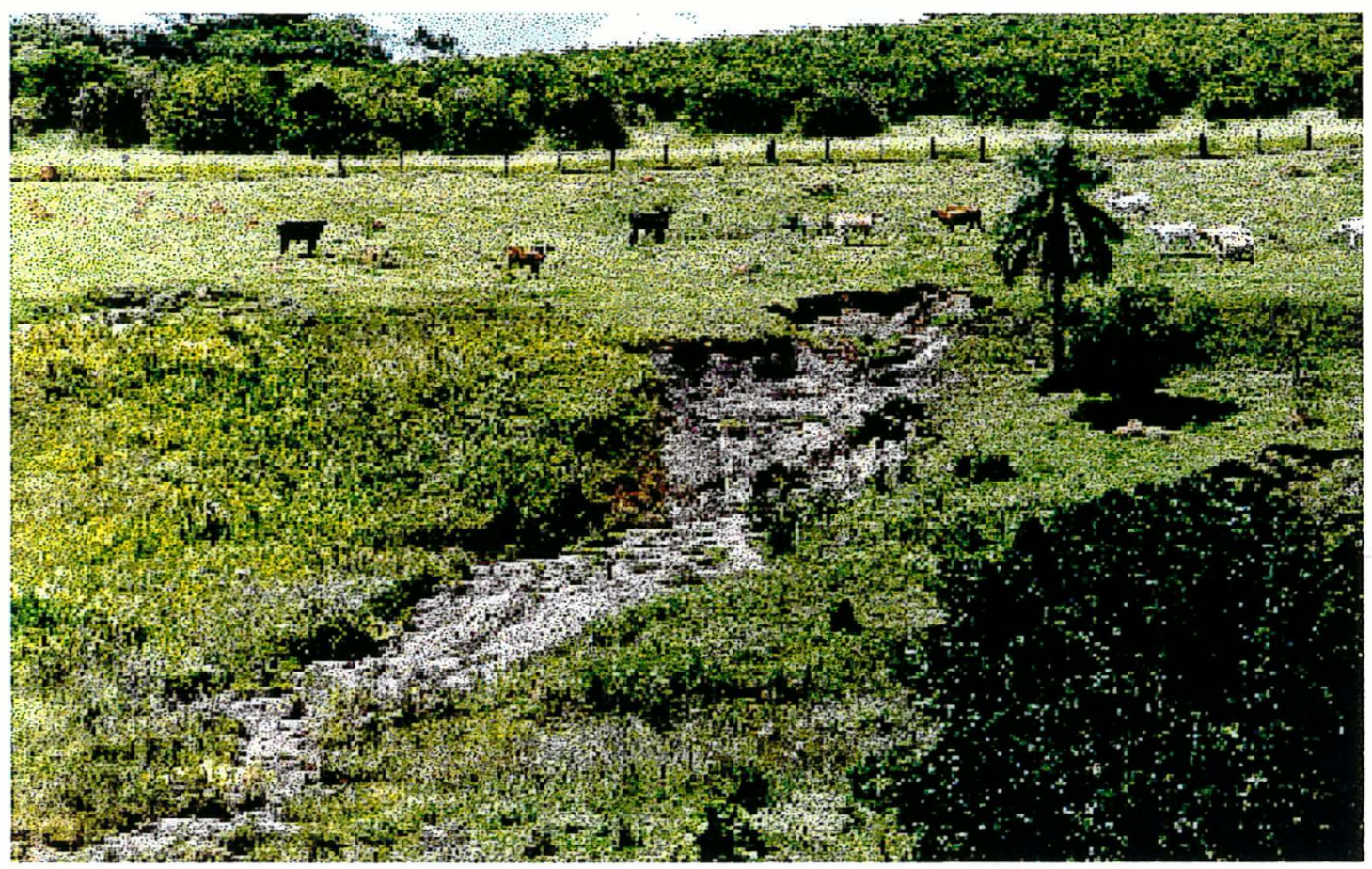

Figura 4. Voçoroca em pastagem, microbacia do Córrego do São Joaquim, Pirassununga, SP.

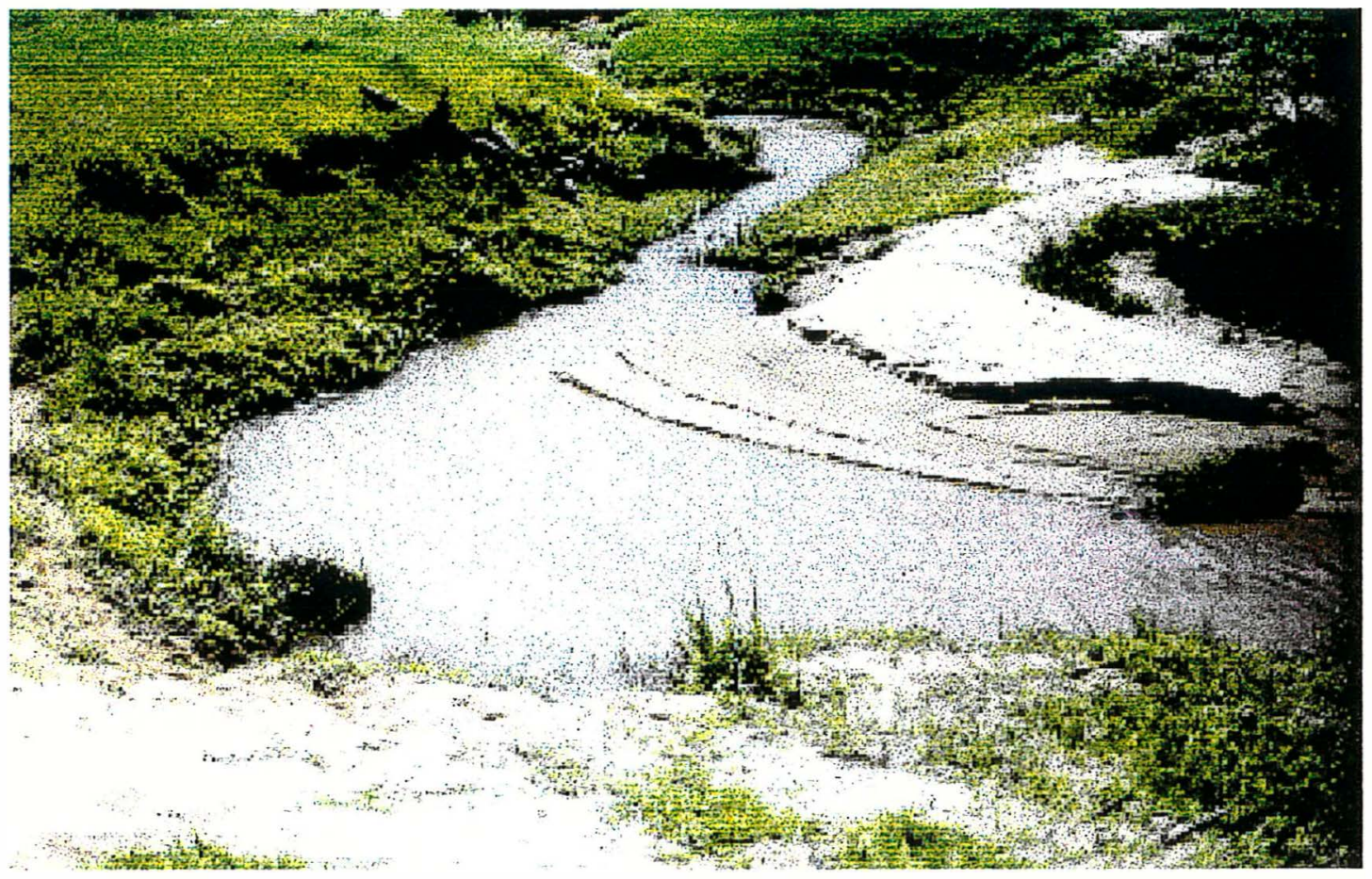

Figura 5. Assoreamento do leito do Córrego São Joaquim, Pirassununga, SP. 
algodão, cultura anual com processo produtivo agressivo ao solo, elevando o risco de erosão.

O processo erosivo evidencia-se também por uma alteração no deflúvio, modificando a hidrologia da microbacia. A menor infiltração das águas das chuvas diminui a recarga dos aqüiferos, tornando maior a amplitude de variação das vazões dos rios, aumentando a ocorrência de enchentes, tanto por maiores volumes instantâneos como pela diminuição da calha pelo assoreamento. Desta forma, a área de influência do impacto começa a extrapolar a área da microbacia.

Não faz parte dos objetivos deste trabalho explicitar todas as implicações do impacto ambiental mencionado. Desta maneira, a análise deter-se-á nos aspectos sobre os efeitos diretos da erosão sobre a dinâmica do solo e da água na restrita pelos divisores da microbacia.

\subsubsection{Erosão hídrica}

A energia de impacto das gotas de chuva sobre o solo e a velocidade de escoamento superficial são fatores determinantes do processo de erosão hídrica e dependem fundamentalmente do tipo de cobertura vegetal existente sobre o solo. Os efeitos positivos de uma adequada cobertura vegetal compreendem: a) controlar a desagregação superficial do solo e evitar sua compactação; b) aumentar a infiltração de água; c) reduzir o deflúvio superficial e o transporte de sedimentos; d) diminuir as perdas de água por evaporação; e) aumentar a capacidade de armazenamento de água no solo.

Como método para se verificar a adequação do uso do solo pelas atividades agropecuárias desenvolvidas, utilizou-se como gabarito as classes de capacidade de uso. Os parâmetros básicos para enquadramento de determinada área são o tipo de solo e a sua declividade. As definições das classes de capacidade de uso, bem como as respectivas exigências de medidas de controle de erosão, achamse apensas ao trabalho (apêndice 1). 
Na microbacia do córrego São Joaquim, a equipe de pedologia do Instituto Agronômico de Campinas (IAC) constatou extrema diversidade de solos, tendo mapeado 21 diferentes unidades (Tabela 4).

Tabela 4. Área e porcentagem das diferentes unidades de solo mapeadas na microbacia do córrego São Joaquim, em hectare, Pirassununga, SP

\begin{tabular}{lrr}
\hline Unidade & \multicolumn{2}{c}{ Area } \\
\hline & ha & $\%$ \\
Latossolo roxo, Ribeirão Preto & 52,56 & 1,73 \\
Latossolo vermelho escuro, Hortolândia & 143,84 & 4,72 \\
Latossolo vermelho escuro, Bonfim & 63,16 & 2,07 \\
Latossolo vermelho amarelo, Três Barras & 521,10 & 17,12 \\
Latossolo vermelho amarelo, Laranja Azeda & 249,57 & 8,20 \\
Latossolo vermelho amarelo, Mato Dentro & 126,30 & 4,15 \\
Podzólico vermelho amarelo, Usina & 483,56 & 15,88 \\
Podzólico vermelho amarelo, Usina "d" & 88,49 & 2,91 \\
Podzólico vermelho amarelo, Olaria & 241,00 & 7,92 \\
Podzólico vermelho amarelo, Alva & 123,27 & 4,05 \\
Podzólico vermelho amarelo, Santa Cruz & 178,59 & 5,87 \\
Podzólico vermelho amarelo, Santa Cruz "s" & 15,77 & 0,52 \\
Podzólico vermelho amarelo, Variante & 64,17 & 2,11 \\
Podzólico vermelho escuro & 29,97 & 0,98 \\
Terra roxa estruturada & 267,48 & 8,79 \\
Areia quartzosa, Analândia & 91,08 & 2,99 \\
Litólico substrato diabásico & 98,28 & 3,23 \\
Litólico substrato folhelho & 56,16 & 4,16 \\
Litólico substrato arenito & 126,72 & 1,84 \\
Cambissolo álico, Sete Lagoas & 18,72 & 0,61 \\
Glei pouco húmico & 4,68 & 0,15 \\
\hline Total & $3.044,47$ & 100,00 \\
\hline Fonte: Hecker Filho \& Olver
\end{tabular}

Fonte: Hecker Filho \& Oliveira (1992).

Os solos podzolizados ( 7 unidades de vermelho-amarelo e 1 de vermelho-escuro) formam o grupo com maior ocorrência, cobrindo cerca de $44 \%$ da área estudada. Seguem-se os latossolos ( 1 unidade de roxo, 2 de unidades de vermelho-escuro e 3 de unidades de vermelho-amarelo), ocupando $34,2 \%$ da área da microḅacia. Completando a descrição dos solos com maior expressão para culturas, tem-se a presença de terra roxa estruturada em cerca de $8,4 \%$ da área. No espaço restante, cerca de 13,4\%, ocorrem ainda, o cambissolo, 3 unidades de litossolos, o solo hidromórfico e areia quartzosa. 
O outro componente que permite a determinação da classe de capacidade de uso é a declividade, e sua distribuição na área da microbacia permite melhor noção sobre o relevo (Tabela 5). Pode-se observar que quase metade da área da microbacia (cerca de 45\%) apresenta declives acima de 12\% de inclinação, fator que demonstra o seu elevado grau de potencial de erosão. Áreas consideradas planas, com até $3 \%$ de declividade, perfazem apenas 7,3\% do total. Esta característica de relevo mais acidentado restringe em muito o uso agrícola das áreas, determinando que mais da metade da mesma seja passivel de uso apenas com pastagens e silvicultura (de exploração e/ou de preservação permanente). Estas condições são melhores explicitadas através do enquadramento das glebas nas respectivas classes de capacidade de uso, segundo suas características de solo e declividade.

Tabela 5. Distribuição da área da microbacia do córrego São Joaquim, em ha e em porcentagem de ocupação, segundo classes de decliyidade, Pirassununga, SP, 1994

\begin{tabular}{ccc}
\hline Classe de declividade & Área \\
\hline $0-3,0$ & ha & 7,30 \\
$3,1-6,0$ & 222,25 & 12,72 \\
$6,1-12,0$ & 387,37 & 34,34 \\
$12,1-20,0$ & $1.045,32$ & 27,19 \\
$20,1-40,0$ & 827,83 & 17,78 \\
$>-40,0$ & 541,15 & 0,67 \\
\hline Total & 20,55 & 100,00 \\
\hline
\end{tabular}

Fonte: Elaborado a partir de dados da Sẹção de Fotointerpretação do Instituto Agronômico de Campinas da Secretaria de Agricultura e Abastecimento (IAC/SAA).

A Tabela 6 apresenta a distribuição atual das explorações agropecuárias da microbacia do córrego São Joaquim por classe de capacidade de uso. Observa-se que, de maneira geral, há ocorrência de todas as classes para todas as atividades, quando seria de se esperar uma certa concentração de freqüência de áreas com culturas nas classes II, III e IV enquanto que áreas com pastagens, reflorestamento e matas naturais ocupariam predomimantemente as classes V,VI e VII (Figuras 6 e 7). 


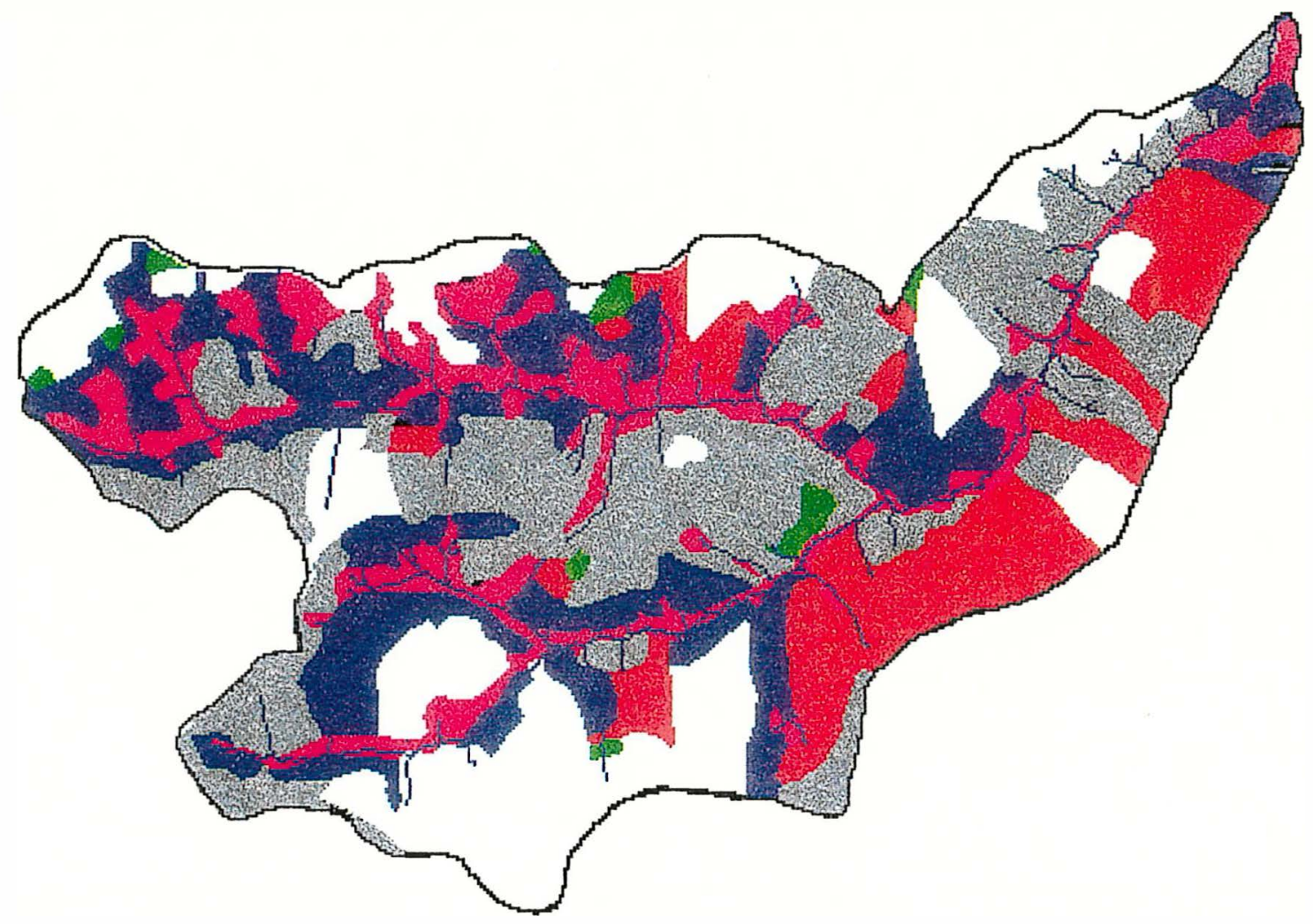

Tipo de Exploração

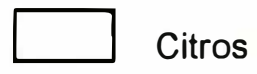

\begin{tabular}{ll}
\hline & Vegetação natural \\
& Culturas anuais \\
& Peflorestamento \\
& Pastagens
\end{tabular}

Figura 6. Distribuição atual da área cultivada, segundo o tipo de exploração, microbacia do Córrego São Joaquim, Pirassununga, S.P. 1994

Fonte: Elaborado a partir de dados da Seção de Fotointerpretação do IAC/SAA. 


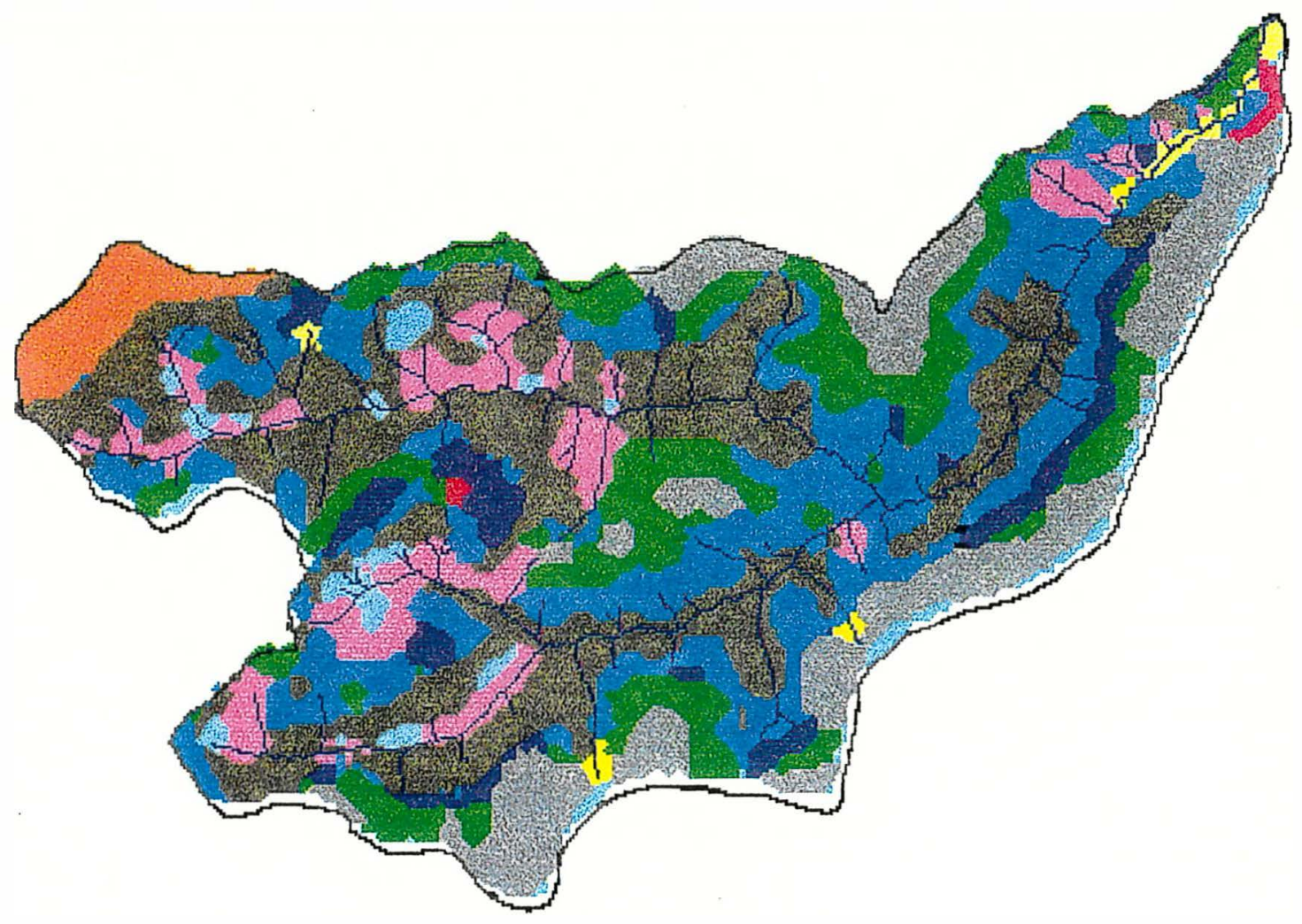

Classe de Capacidade de Uso ( $\left.{ }^{1}\right)$

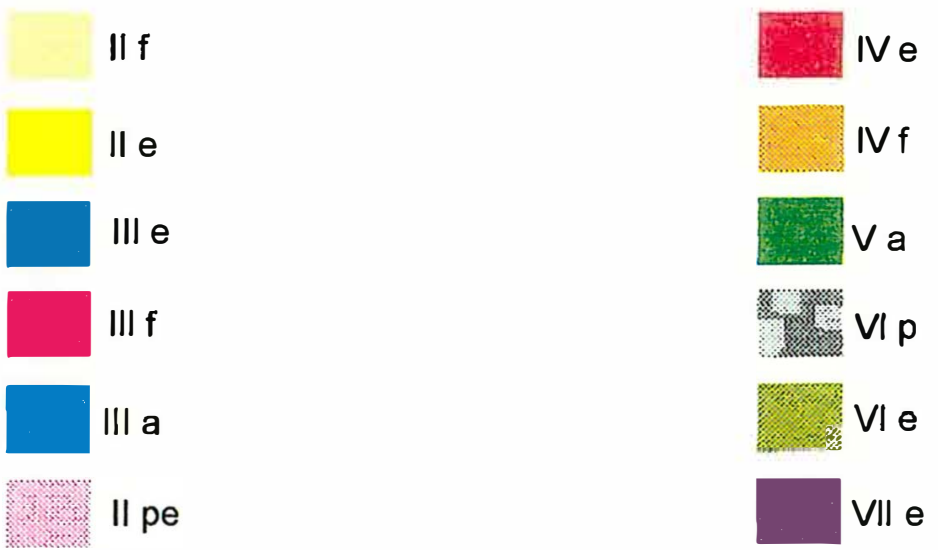

Figura 7. Distribuição da área da microbacia do Córrego São Joaquim, segundo classe de capacidade de uso, Pirassununga, SP, 1994.

$\left({ }^{1}\right)$ Restrição: fertilidade (f), erosão (e), drenagem (a), profundidade (p) e pedregosidade (pe). Fonte: Elaborado a partir de dados da Seção de Fotointerpretação do IAC/SAA. 
Tabela 6. Área das atividades exploradas, por classe de capacidade de uso, microbacia do córrego São Joaquim, Pirassununga, SP, 1994

\begin{tabular}{|c|c|c|c|c|c|c|c|}
\hline $\begin{array}{c}\text { Capacidade } \\
\text { de uso (1) }\end{array}$ & Citros & $\begin{array}{c}\text { Cana-de } \\
\text { açúcar }\end{array}$ & $\begin{array}{r}\text { Culturas } \\
\text { anuais }\end{array}$ & Pastagens & $\begin{array}{c}\text { Reflores- } \\
\text { tamento }\end{array}$ & $\begin{array}{c}\text { Matas } \\
\text { naturais }\end{array}$ & Total \\
\hline$\| f$ & 147,60 & 87,43 & 154,08 & 13,68 & 5,40 & 4,68 & 412,87 \\
\hline II e & - & 2,88 & - & - & - & - & 2,88 \\
\hline III e & 44,64 & 49,32 & 32,76 & 24,84 & - & 10,08 & 161,64 \\
\hline III $f$ & 166,32 & 173,52 & 56,16 & 27,36 & 15,48 & 4,68 & 443,52 \\
\hline III a & - & - & - & 6,12 & - & 3,60 & 9,72 \\
\hline III pe & 4,32 & 1,80 & 3,60 & - & 1,08 & 0,72 & 11,52 \\
\hline IV e & 94,32 & 233,64 & 91,80 & 190,08 & 11,52 & 57,60 . & 678,96 \\
\hline IV $f$ & 47,88 & - & - & 27,72 & 11,52 & 2,16 & 89,28 \\
\hline $\mathrm{Va}$ & - & 7,20 & 1,08 & 2,88 & - & 11,16 & 22,32 \\
\hline VIp & 13,32 & 66,96 & 3,96 & 62,28 & - & 105,48 & 252,00 \\
\hline VIe & 123,48 & 198,00 & 59,40 & 248,04 & 2,16 & 231,12 & 862,20 \\
\hline VII e & 19,08 & 14,04 & 17,28 & 18,36 & - & 28,80 & 97,56 \\
\hline Total & 660,96 & 834,79 & 420,12 & 621,36 & 47,16 & 460,08 & 3044,47 \\
\hline
\end{tabular}

(1) Restrição: erosão (e), fertilidade (f), drenagẹm (a), profundidade (p) e pedregosidade (pe). Fonte : Elaborado com dados da Seção de Fotọinterpretação do IAC/SAA.

O uso com culturas englobando citros, cana-de-açúcar e principais culturas anuais (algodão, milho e soja) soma 1.915,87 ha, perto de $63 \%$ da área total. Como já citado anteriormente, a cana-de-açúcar é a atividade com maior expressão, tendo sido mapeados 834,79 ha com essa cultura, $27,4 \%$ da área total da microbacia. Seguem-se citros com 660,96 ha $(21,7 \%)$ e pastagem com 621,36 ha $(20,4 \%)$.

Todavia, como mostra a Tabela 7, essas atividades deveriam estar sendo desenvolvidas apenas nas classes II, III e IV, respeitadas as respectivas restrições. Para se ter um controle de erosão ideal, esta área deveria ser reduzida para cerca de 1.300ha e ocupada por citros em 505,08ha, por cana-de-açúcar em 548,59ha e por culturas anuais em $246,60 \mathrm{ha}$. Tanto em termos relativos como absolutos, a cana-de-açúcar é a cultura encontrada em mais áreas $(286,20 \mathrm{ha})$ não adequadas ao seu cultivo (cerca de $35 \%$ do total com esta cultura) (Figura 8 ).

A área ocupada com vegetação natural corresponde a $15,1 \%$ do total, e ocorre com maior peso nas classes mais inclinadas, embora esteja presente também nas demais classes, pois em várias propriedades esta acompanha a drenagem, configurando a mata ripária remanescente. 


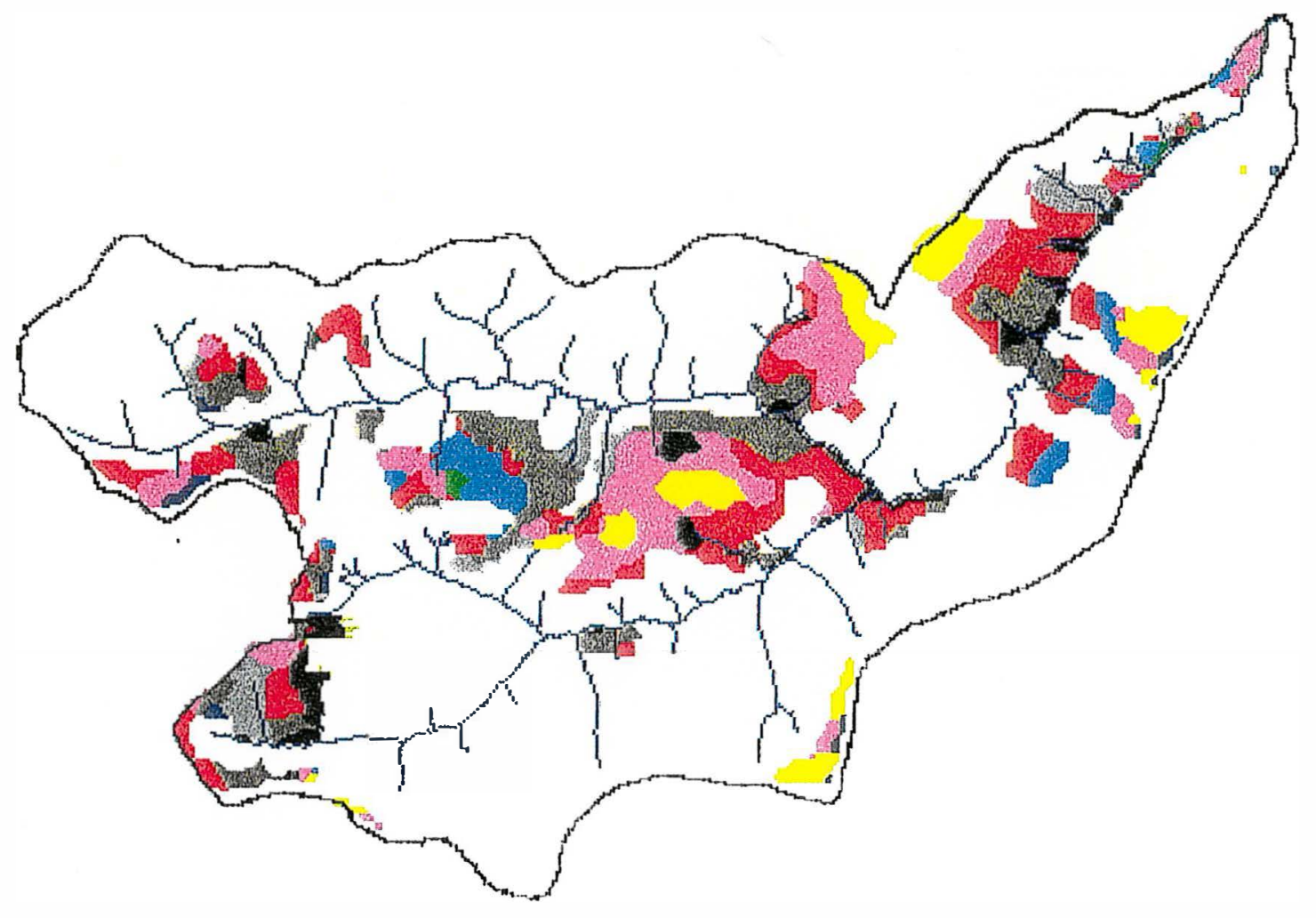

\section{Classe de Capacidade de Uso ( $\left.{ }^{1}\right)$}

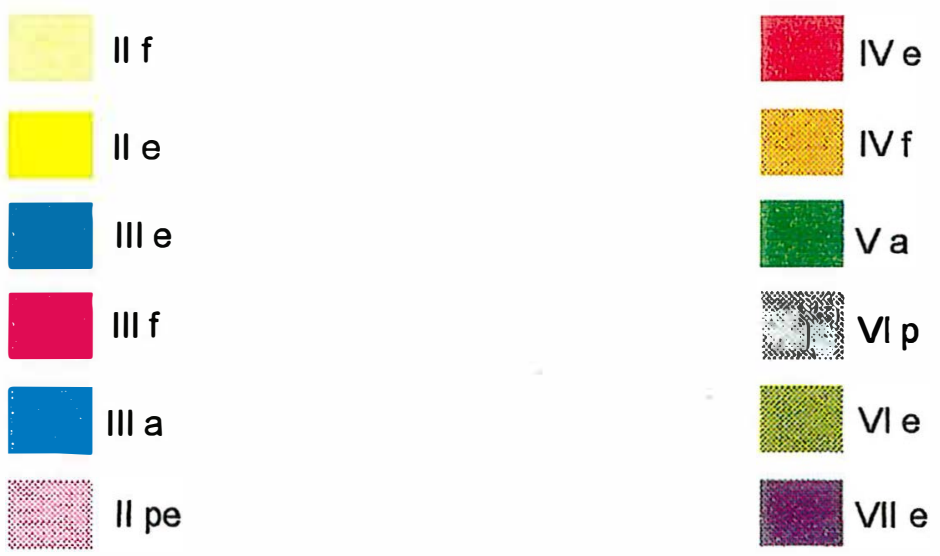

Figura 8. Distribuição da área ocupada com cana-de-açúcar, segundo a classe de capacidade de uso, Microbacia de São Joaquim, Pirassununga, S.P. 1994

$\left({ }^{1}\right)$ Restrição: fertilidade (f), erosão (e), drenagem (a), profundidade (p) e pedregosidade (pe). Fonte: Elaborado a partir de dados da Seção de Fotointerpretação do IAC/SAA. 
Como se pode observar nas Tabelas 6 e 7, dos 3.044,47ha de área explorada atualmente na microbacia, apenas $1.871,23 \mathrm{ha}$ (61,5\%) são exploradas adequadamente, segundo as classes de uso de solo.

Tabela 7. Áreas exploradas com atividades adequadas à classe de capacidade de uso, microbacia do córrego São Joaquim, Pirassununga; SP, 1994 (1)

(em hectare)

\begin{tabular}{lccccccr}
\hline $\begin{array}{l}\text { Capacidade } \\
\text { de uso (2) }\end{array}$ & Citros & $\begin{array}{c}\text { Cana-de- } \\
\text { açúcar }\end{array}$ & $\begin{array}{c}\text { Culturas } \\
\text { anuais }\end{array}$ & Pastagens & $\begin{array}{c}\text { Reflores- } \\
\text { tamento }\end{array}$ & $\begin{array}{c}\text { Matas } \\
\text { naturais }\end{array}$ & \multicolumn{1}{c}{ Total } \\
\hline II f & 147,60 & 87,43 & 154,08 & $\mathrm{~s} \mathrm{u}$ & $\mathrm{s} \mathrm{u}$ & $\mathrm{s} \mathrm{u}$ & 389,11 \\
II e & - & 2,88 & - & $\mathrm{s} \mathrm{u}$ & $\mathrm{s} \mathrm{u}$ & $\mathrm{s} \mathrm{u}$ & 2,88 \\
III e & 44,64 & 49,32 & 32,76 & $\mathrm{~s} \mathrm{u}$ & $\mathrm{s} \mathrm{u}$ & $\mathrm{s} \mathrm{u}$ & 126,72 \\
III f & 166,32 & 173,52 & 56,16 & $\mathrm{~s} \mathrm{u}$ & $\mathrm{s} \mathrm{u}$ & $\mathrm{s} \mathrm{u}$ & 396,00 \\
III a & $\mathrm{i}$ & - & - & $\mathrm{s} \mathrm{u}$ & $\mathrm{s} \mathrm{u}$ & $\mathrm{s} \mathrm{u}$ & 0,00 \\
III pe & 4,32 & 1,80 & 3,60 & $\mathrm{~s} \mathrm{u}$ & $\mathrm{s} \mathrm{u}$ & $\mathrm{s} \mathrm{u}$ & 9,72 \\
IV e & 94,32 & 233,64 & $\mathrm{p} \mathrm{a}$ & 190,08 & $\mathrm{~s} \mathrm{u}$ & $\mathrm{s} \mathrm{u}$ & 518,04 \\
IV f & 47,88 & - & $\mathrm{p} \mathrm{a}$ & 27,72 & $\mathrm{~s} \mathrm{u}$ & $\mathrm{s} \mathrm{u}$ & 75,60 \\
V a & $\mathrm{i}$ & $\mathrm{i}$ & $\mathrm{i}$ & 2,88 & $\mathrm{~s} \mathrm{u}$ & 11,16 & 14,04 \\
VI p & $\mathrm{i}$ & $\mathrm{i}$ & $\mathrm{i}$ & 62,28 & $\mathrm{~s} \mathrm{u}$ & $\mathrm{s} \mathrm{u}$ & 62,28 \\
VI e & $\mathrm{i}$ & $\mathrm{i}$ & $\mathrm{i}$ & 248,04 & $\mathrm{~s} \mathrm{u}$ & $\mathrm{s} \mathrm{u}$ & 248,04 \\
VII e & $\mathrm{i}$ & $\mathrm{i}$ & $\mathrm{i}$ & $\mathrm{p} \mathrm{a}$ & - & 28,80 & 28,80 \\
\hline Total & 505,08 & 548,59 & 246,60 & 531,00 & - & 39,96 & 1871,23 \\
\hline
\end{tabular}

Uso: $\mathrm{i}=$ inadequado, $\mathrm{pa}=$ pouco adequado e su $=$ sub-utilizado.

Restrição: erosãp (e), fertilidade ( $f$ ), drenagem (a), profundidade (p) e pedregosidade (pe).

Fonte : Elaborado com dados da Seção de Fotọinterpretação do IAC/SAA.

As áreas com exploraçăo adequada à capacidade de uso (1.871,23ha), somadas às com uso pouco adequados $(110,16 \mathrm{ha})$ e com as de exploração aquém de suas possibilidades ( 539,28 ha sub-utilizados) perfazem $2.520,67$ ha, ou seja, $82,8 \%$ da área total de microbacia (Tabelas 8 e 9). Nessas glebas, uma vez utilizadas as técnicas preconizadas para controle de erosão, há possibilidade de redução da perda de solo, adequando-a aos respectivos limites de tolerância de cada tipo de solo. Para essas áreas, neste estudo, o plano com açōes para minimizar a perda do solo por erosão hídrica não prevê a introdução de atividades de produção novas ou inexistentes na microbacia. 
Tabela 8. Áreas exploradas com atividades pouco adequadas à classe de capacidade de uso, microbacia do córrego São Joaquim, Pirassununga, SP, 1994 (1)

(em hectare)

\begin{tabular}{|c|c|c|c|c|c|c|c|}
\hline $\begin{array}{l}\text { Capacidade } \\
\text { de uso (2) }\end{array}$ & Citros & $\begin{array}{l}\text { Cana-de- } \\
\text { açúcar }\end{array}$ & $\begin{array}{c}\text { Culituras } \\
\text { anuais }\end{array}$ & Pastagens & $\begin{array}{c}\text { Reflores- } \\
\text { tamento }\end{array}$ & $\begin{array}{c}\text { Matas } \\
\text { naturais }\end{array}$ & Total \\
\hline$\| f$ & a & $a$ & $a$ & $\mathrm{su}$ & $s u$ & $\mathrm{su}$ & 0,00 \\
\hline$\| \mathrm{e}$ & a & a & a & su & su & su & 0,00 \\
\hline III e & a & a & a & su & su & su & 0,00 \\
\hline III f & a & a & $a$ & su & su & su & 0,00 \\
\hline III a & $\mathbf{i}$ & a & a & su & su & su & 0,00 \\
\hline III pe & a & a & $a$ & su & su & su & 0,00 \\
\hline IV e & a & a & 91,80 & $a$ & su & $\mathrm{su}$ & 91,80 \\
\hline IV $f$ & a & a & - & a & $\mathrm{su}$ & su & 0,00 \\
\hline $\mathrm{Va}$ & $\mathbf{i}$ & $\mathbf{i}$ & $\mathbf{i}$ & a & $\mathbf{i}$ & $a$ & 0,00 \\
\hline VI p & $i$ & i & $\mathbf{i}$ & a & su & su & 0,00 \\
\hline $\mathrm{VIe}$ & $\mathbf{i}$ & $\mathbf{i}$ & $\mathbf{i}$ & $a$ & su & su & 0,00 \\
\hline VII e & $i$ & i & $i$ & 18,36 & $a$ & $a$ & 18,36 \\
\hline Total & 0,00 & 0,00 & 91,80 & 18,36 & 0,00 & 0,00 & 110,16 \\
\hline
\end{tabular}

Uso: $a$ = adequado, $i$ = inadequado e su = sub-utilizado.

Restrição: erosão (e), fertilidade ( $f$ ), drenagem (a), profundidade $(p)$ e pedregosidade (pe).

Fonte : Elaborado com dados da Seção de Fotointerpretação do IAC/SAA.

Tabela 9. Áreas exploradas com atividades que sub-utilizam a capacidade de uso do solo, microbacia do córrego São Joaquim, Pirassununga, SP, 1994 (1)

\begin{tabular}{lccccccr}
\hline $\begin{array}{l}\text { Capacidade } \\
\text { de uso (2) }\end{array}$ & Citros & $\begin{array}{c}\text { Cana-de- } \\
\text { açúcar }\end{array}$ & $\begin{array}{c}\text { Culturas } \\
\text { anuais }\end{array}$ & Pastagens & $\begin{array}{c}\text { Reflores- } \\
\text { tamento }\end{array}$ & $\begin{array}{c}\text { Matas } \\
\text { naturais }\end{array}$ & Total \\
\hline II f & a & a & a & 13,68 & 5,40 & 4,68 & 23,76 \\
II e & a & a & a & - & - & - & 0,00 \\
III e & a & a & a & 24,84 & - & 10,08 & 34,92 \\
III f & a & a & $a$ & 27,36 & 15,48 & 4,68 & 47,52 \\
III a & a & a & a & 6,12 & - & 3,60 & 9,72 \\
III pe & a & a & a & - & 1,08 & 0,72 & 1,80 \\
IV e & a & a & pa & a & 11,52 & 57,60 & 69,12 \\
IV f & a & a & pa & a & 11,52 & 2,16 & 13,68 \\
V a & i & i & i & a & i & a & 0,00 \\
VI p & i & i & i & a & - & 105,48 & 105,48 \\
VI e & i & i & i & a & 2,16 & 231,12 & 233,28 \\
VII e & i & i & i & p a & a & a & 0,00 \\
\hline Total & - & - & - & 72,00 & 47,16 & 420,12 & 539,28 \\
\hline
\end{tabular}

Uso: $a=$ adequado, $\mathrm{i}=$ inadequado e $\mathrm{pa}=$ pouco adequado.

Restrição: erosão (e), fertilidade (f), drenagem (a), profundidade $(p)$ e pedregosidade (pe).

Fonte : Elaborado com dados da Seção de Foteinterpretação do IAC/SAA. 
As áreas consideradas com problemas quanto à utilização agrícola, ou seja, aquelas onde a exploração se dá por meio de uma atividade que impõe ao solo ações físicas além do limite de tolerânçia, e portanto, o expõe à erosão hídrica, somam 523,80 ha $(17,2 \%$ da área total) (Tabela 10).

A cana-de-açúcar se destaca com $54,6 \%$ da área inadequadamente explorada, sendo que os 286,20 ha assim utilizados representam cerca de $1 / 3$ da área com esta cultura na microbacia. Observam-se 198,00ha com cana-de-açúcar, na classe VI, em solos com características de maior propensão à erosão e em declividades acentuadas.

Para o controle da erosão nestas glebas com exploração inadequada impõe-se, necessariamente, a substituição da atividade por vegetação natural (matas) ou pastagem, enquadrando-as segundo as respectivas tolerâncias.

Tabela 10. Áreas exploradas com atividades inadequadas à classe de capacidade de uso, microbacia do Córrego São Joaquim, Pirassununga, SP, 1994 (1) (em hectare)

\begin{tabular}{|c|c|c|c|c|c|c|c|}
\hline $\begin{array}{l}\text { Capacidade } \\
\text { de uso (2) }\end{array}$ & Citros & $\begin{array}{c}\text { Cana-de- } \\
\text { açúcar }\end{array}$ & $\begin{array}{c}\text { Culturas } \\
\text { anuais }\end{array}$ & Pastagens & $\begin{array}{r}\text { Reflores- } \\
\text { tamento }\end{array}$ & $\begin{array}{c}\text { Matas } \\
\text { naturais }\end{array}$ & Total \\
\hline \|f $\mathbf{f}$ & a & $\mathbf{a}$ & $a$ & s u & su & $\mathbf{s u}$ & 0,00 \\
\hline$\| \mathrm{e}$ & a & a & a & su & s u & $\mathbf{s u}$ & 0,00 \\
\hline III e & a & a & a & s u & su & su & 0,00 \\
\hline III f & a & a & a & su & su & su & 0,00 \\
\hline III a & - & a & a & su & su & su & 0,00 \\
\hline III pe & a & a & a & su & su & su & 0,00 \\
\hline IV e & $a$ & a & pa & a & s u & $\mathrm{su}$ & 0,00 \\
\hline IV f & a & $a$ & pa & a & s u & su & 0,00 \\
\hline V a & - & 7,20 & 1,08 & a & - & $a$ & 8,28 \\
\hline VI p & 13,32 & 66,96 & 3,96 & a & $\mathbf{s u}$ & su & 84,24 \\
\hline VI e & 123,48 & 198,00 & 59,40 & a & su & $\mathbf{s u}$ & 380,88 \\
\hline VII e & 19,08 & 14,04 & 17,28 & pa & $a$ & $a$ & 50,40 \\
\hline Total & 155,88 & 286,20 & 81,72 & - & - & - & 523,80 \\
\hline
\end{tabular}

Uso: $\mathrm{a}=$ adequado, $\mathrm{pa}=$ pouco adequado e su $=$ sub-utilizado.

Restrição: erosão (e), fertilidade (f), drenagem (a), profundidade (p) e pedregosidade (pe).

Fonte : Elaborado com dados da Seção de Fotọinterpretação do IAC/SAA. 


\subsubsection{Perdas de Solo}

As estimativas de perda de solo foram apuradas através da Equação Universal de Perda de Solo (EUPS):

$$
A=R \times K \times L \times S \times C \times P
$$

As propriedades do solp, que determinam sua chamada erodibilidade, se traduzem em efeitos como velocidade de infiltração, permeabilidade, capacidade de armazenamento da água e resistência a dispersão. $O$ peso do componente propriedades do solo no processo erosivo é estimado pelo fator $K$ - erodibilidade expresso em t.h./MJ.mm ${ }^{10}$, e é utilizado como variável na EUPS. Os valores de $\mathrm{K}$ para os solos presentes na microbacia de São Joaquim encontram-se na Tabela 11.

Tabela 11. Área, erodibilidade e tolerância de perdas para as unidades de solo da microbacia do Córrego São Joaquim, Pirassununga, SP

\begin{tabular}{lrcc}
\hline Solo & \multicolumn{1}{c}{ Área } & $\mathrm{K}$ & Tolerância \\
\hline & \multicolumn{1}{c}{ ha } & t.h/MJ.mm & t/ha \\
Latossolo roxo, Ribeirão Preto & 52,56 & 0,0098 & 13,0 \\
Latossolo vermelho escuro, Hortolândia & 143,84 & 0,0175 & 13,0 \\
Latossolo vermelho escuro, Bonfim & 63,16 & 0,0167 & 12,3 \\
Latossolo vermelho amarelo, Três Barras & 521,10 & 0,0132 & 14,2 \\
Latossolo vermelho amarelo, Laranja Azeda & 249,57 & 0,0132 & 14,2 \\
Latossolo vermelho amarelo, Mato Dentro & 126,30 & 0,0246 & 12,6 \\
Podzólico vermelho amarelo, Usina & 483,56 & 0,0462 & 9,6 \\
Podzólico vermelho amarelo, Usina "d" & 88,49 & 0,0462 & 9,6 \\
Podzólico vermelho amarelo, Olaria & 241,00 & 0,0280 & 9,9 \\
Podzólico vermelho amarelo, Alva & 123,27 & 0,0462 & 9,6 \\
Podzólico vermelho amarelo, Santa Cruz & 178,59 & 0,0280 & 9,9 \\
Podzólico vermelho amarelo, Santa Cruz: "s" & 15,77 & 0,0280 & 9,9 \\
Podzólico vermelho amarelo, Variante & 64,17 & 0,0266 & 11,0 \\
Podzólico vermelho escuro & 29,97 & 0,0357 & 7,7 \\
Terra roxa estruturada & 267,48 & 0,0181 & 13,4 \\
Areia quartzosa, Analândia & 91,08 & 0,0296 & 8,2 \\
Litólico substrato diabásico (Li1) & 98,28 & 0,0442 & 6,7 \\
Litólico substrato folhelho (Li2) & 56,16 & 0,0302 & 7,4 \\
Litólico substrato arenito (Li3) & 126,72 & 0,0362 & 6,4 \\
Cambissolo álico, Sete Lagoas (CB) & 18,72 & 0,0350 & 6,4 \\
Glei pouco húmico (Hi) & 4,68 & - & - \\
\hline
\end{tabular}

Fonte: Dados da Seção de Fotointerpretação do IAC/SAA.

\footnotetext{
${ }^{10}$ Tonelada.hora por megajoule.milimetro. Um megajoule = 1 milhão de joules, medida de força.
} 
A utilização de um Siștema de Informação Geográfica (SIG) tornou possível a superposição gráfica dos mapas de solos, planialtimétrico, drenagem e uso atual da terra na microbacia do córrego São Joaquim. Isto permitiu a geração de informações necessárias para a análise ambiental e o cálculo da perda de solo através da EUPS. Foram estabelecidos os valores da erodibilidade para cada unidade de solo, assim como também para as respectivas tolerâncias de perda de solo. Estes valores foram depois ponderados segundo suas participações percentuais em relação à área total, fornecendo os parâmetros para aplicação na EUPS: o valor médio de perda de solo encontrado para a microbacia foi de 10,66 t/ha/ano.

Um fator de grande influência na determinação da intensidade de erosão é o tipo de declive da gleba, tanto pelo comprimento da rampa como pelo grau de inclinação. Na EUPS esses efeitos são considerados pelos índices $L$ e $S$, separadamente. Bertoni \& Lombardi Neto (1990) propõem uma equação para considerá-los como um único parâmetro, ao qual denominam fator topográfico. Este foi o método utilizado neste trabalho para se estimar um fator topográfico médio ponderado para a área, de 3,2374 (adimensional), utilizando-se valores de $L$ e $S$ obtidos cartograficamente através do SIG. Aos fatores $L$ e $S$ associou-se também o fator "P" que mede a redução da perda de solo pelo uso e eficácia de práticas conservacionistas; para efeito do cálculo da perda atual de solo, como praticamente não há controle efetivo da erosão, $Q$ fator " $P$ " recebeu o valor unitário $(P=1)$. Tal procedimento foi utilizado por Lombardi Neto et al. (1997) ao realizarem o planejamento agroambiental da microbacia do ribeirão Cachoeirinha, em Iracemápolis, SP. Os mesmos autores estimaram o valor da erosibilidade total da chuva, $R=7.103$ MJ.mm/ha.h, aplicável também à área da microbacia do córrego São Joaquim.

$O$ fator erodibilidade $-K_{\text {médio }}=0,0285$ t.h/MJ.mm- foi obtido mediante ponderação baseada na área de cada unidade de solo presente na microbacia e pode ser utilizado também para se estimar a perda de solo, considerando-se o uso atual do solo na microbacia. Para o valor de $C$ (coeficiente de enxurrada) ponderou-se o correspondente a cada grupo de atividade, segundo a área, conforme Bertoni \& Lombardi Neto (1990), estabelecendo-se um valor médio ponderado de $C$ para o uso atual da microbacia, conforme Tabela 12. 
TABELA 12. Estimativa do valor médio do parâmetro $C$ para o uso atual do solo, microbacia do São Joaquim, Pirassununga, SP, 1994

\begin{tabular}{lccc}
\hline Uso atual & Área & $\mathrm{C}_{\text {uso atual }}$ & $\mathrm{C}_{\text {ponderado }}$ \\
\hline Citros & 660,96 & 0,087 & 0,0189 \\
Cana-de-açúcar & 834,79 & 0,107 & 0,0293 \\
Culturas anuais & 420,12 & 0,177 & 0,0244 \\
Pastagem & 621,36 & 0,010 & 0,0020 \\
Reflorestamento & 47,16 & 0,047 & 0,0007 \\
Vegetação natural & 460,08 & 0,004 & 0,0006 \\
\hline Valor de C médio ponderado & & & 0,0760 \\
\hline
\end{tabular}

Fonte: Baseado em Lombardi Neto (1997) ${ }^{11}$

Considerada a atual cọbertura do solo, e com os parâmetros acima mencionados foi possível estimar o valor anual da perda média de solo, por hectare e para toda a microbacia:

$$
\begin{aligned}
& A=\operatorname{LSP} \times \quad \times \quad K \quad \times \quad C \times R \\
& A=3,2374 \times 0,0285 \times 0,076 \times 7.103=49,81 . . t / \text { ha/ano }
\end{aligned}
$$

Perda na área da microbacia $=49,81 \times . .3 .044,47=151.638$ t/ano

ou seja, consideradas a atual cobertura vegetal, os tipos de solo, a pluviosidade média do local, as declividades médias de cada gleba, estima-se uma elevada perda de solo. Observa-se que esta perda é quase o quíntuplo do valor esperado (10,66 t/ha/ano) respeitados os limites médios de tolerância para os diferentes solos lá encontrados.

\subsubsection{Arrasto de sedimentos}

Um dos efeitos do manejo inadequado do solo, seja para uso agrícola ou para construção de estradas, é o assoreamento de cursos d'água e represas. Nesses casos a agressão física ao rio é bastante visível, reduzindo sua calha e

\footnotetext{
${ }^{11}$ Lombardi Neto, F. (IAC. Seção de Fotainterpretação) Comunicação pessoal, 1997.
} 
aumentando o risco de enchentes; em represas, ela reduz a capacidade de armazenamento e, conseqüentemente, o potencial energético e sua vida útil, comprometendo investimentos vultuosps.

Conhecendo-se a relação de aporte de sedimentos -"sediment delivery ratio" (SDR), pode-se estimar o volume de material que poderá passar a ser retido com a adoção das medidas mitigadoras (Apêndice 1). O SDR é um indicador da quantidade de sedimento que atinge o curso d'água, cujo valor para a microbacia em estudo é de 0,235 (adimendional) $^{12}$, Considerando-se os fatores - a) a estimativa da atual perda de solo em 49,81 t/ha/ano; b) o nivel de perda tolerável 10,66 t/ha/no; c) as características de relevo da microbacia - o volume de sedimentos que poderá deixar de chegar ao córrego é dado por:

$$
\begin{aligned}
& V=(\text { perda de solo }) \times \operatorname{SDR}=\left(V_{\text {atual }}-V_{\text {tolerável }}\right) \times \operatorname{SDR} \\
& V=(49,81-10,66) \times 0,235=9,20 \text { t/ha/ano }
\end{aligned}
$$

Desta forma, uma vez aplicadas as medidas de controle que reduzam a erosão ao nivel de tolerância de cada gleba, calcula-se que 28.010 toneladas de sedimentos $(9,2$ t/ha/ano $\times 3.044,47$ ha) poderiam deixar de chegar ao córrego todo ano. Para esse mesmo volume de solo que deixará de ser perdido é possivel realizar uma estimativa da quantidade de nutrientes que flui junto com o solo. Segundo Bellinazzi Junior et al. (1981), cada tonelada de solo que se perde por erosão possui o teor médio de nitrogênio $(N)$ correspondente à $4,835 \mathrm{~kg}$ de sulfato de amônio, o teor médio de fósforo $(P)$ correspondente à $0,1448 \mathrm{~kg}$ de superfosfato simples, o teor médio de potássio $(K)$ correspondente à $0,1678 \mathrm{~kg}$ de cloreto de potássio e teor médio de cálcio $(\mathrm{Ca})$ correspondente à $2,495 \mathrm{~kg}$ de calcário dolomítico.

Os valores aplicados aos parâmetros da microbacia correspondentes ao volume de solo perdido além do limite tolerável, $V=V_{\text {perda atual }}-V_{\text {perda tolerável }}=49,81$ $10,66=39,15 \mathrm{t} / \mathrm{ha}$, permitem estabelecer as seguintes estimativas de perdas para a microbacia como um todo:

- sulfato de amônio $=39,15 \times 0,004835 \times 3.044,47=576,29$ t/ano;

${ }^{12}$ Lombardi Neto, F. (IAC. Seção de Fotointerpretação) Comunicação pessoal, 1997 
- superfosfato simples $=39,15 \times 0,0001448 \times 3.044,47=17,26$ t/ano

- cloreto de potássio $=39,15 \times 0,0001678 \times 3.044,47=20,00$ t/ano;

- calcário dolomítico $=39,15 \times 0,002495 \times 3.044,47=297,38$ t/ano.

Através de dados de pesquisa mencionada por Bertoni \& Lombardi Neto (1990), que indicam a queda de produtividade devido à perda de determinada altura da camada superficial do solo, e sabedores do volume de solo perdido em cada unidade, pela EUPS, é possivel estimar qual poderia vir a ser a queda de produtividade, por tipo de unidade de solo encontrada na microbacia em estudo. Desta maneira, considerando-se uma ponderação por área de unidade de solo ocupada por cultura e um horizonte de análise de 20 anos, foi possivel obter as seguintes taxas de perdas médias anuais de produtividade: de 1,26\% ao ano para as áreas com citros; de 1,40\% para as com cana-de-açúcar; de 1,49\% para as com culturas anuais; de 1,70\% para as áreas ocupadas com pastagens, Os procedimentos que permitiram obter tais estimativas acham-se em tabelas do Apêndice 2.

\subsubsection{Mata ripária}

A mata ripária, também conhecida como de galeria ou matas ciliares, são formações vegetais que se desenvolvem ao longo dos rios, sendo consideradas pela maioria dos autores como elemento típico do quadro ecológico tropical, notórias nas paisagens das savanas africanas e nos cerrados brasileiros, segundo Troppmair \& Machado (1974). Ainda com relação à denominação, citam que por se apresentarem margeando rios receberam também, de botânicos europeus, o nome de mata fluvial ou mata marginal; e, considerando a forma de pestanas como se dispõem ao longo dos cursos d’água, têm sido mais usualmente tratadas por mata ripária. 
A preservação e a recuperação de mata ripária é fundamental para a manutenção da sustentabilidade do sistema ambiental onde acha-se inserida. Entre os principais benefícios pode-se destacar: redução do solapamento das margens dos rios; preservação de fontes e nascentes; refúgio à fauna; proteção ao curso d’água pela filtragem de resíduos do processo produtivo agrícola (fertilizantes, corretivos e defensivos); ampliação das possibilidades de recarga do aqüifero.

A variedade das plantas que compõem a mata ripária está diretamente relacionada com um conjunto de fatores, entre os quais se destacam a profundidade do lençol freático, o microclima, o microrelevo, a estrutura do solo, o traçado e sobretudo a ação antrópica. Desta forma, como os fatores mudam, pode-se encontrar na microbacia do córrego São Joaquim várias formas de expressão da mata de galeria, sub-conjunto das áreas cobertas por matas naturais, mostradas na Figura 9. Na parte superior, com relevo mais acidentado, o ribeirão tem cerca de $1 \mathrm{~m}$ de largura, e há presença de vegetação arbórea e arbustiva com espécies entre $10 \mathrm{~m}$ e $20 \mathrm{~m}$ de

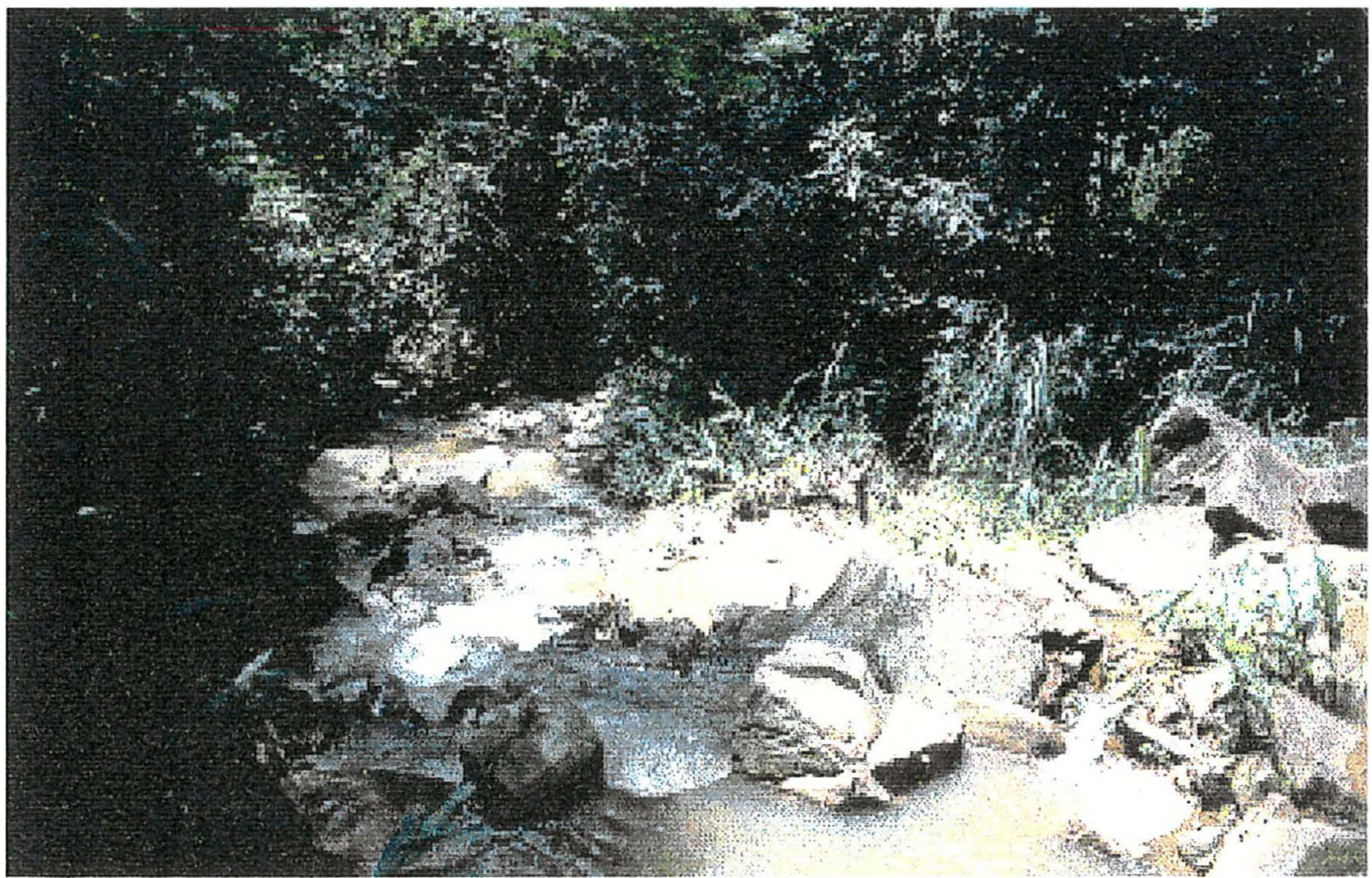

Figura 9. Mata ripária, microbacia do córrego São Joaquim, Pirassununga, SP. 
altura, com as árvores tornando-se mais altas quando mais afastadas das margens; este tipo de sistema assume característica típica de "grotão", com pouca alteração humana e que pode ser confundida com mata de encosta. Acompanhando o ribeirão, em sua parte média, quando o terreno vai adquirindo um contorno mais suave, a vegetação vai escasseando e em muitos lugares é inexistente, com o pasto e suas cercas praticamente dentro do leito.

Em sua parte final, nas proximidades do desague no ribeirão Descaroçador, o córrego apresenta perto de 10m de largura, em terreno com declividade suave e, portanto, com escoamento mais lento. Suas margens adquirem novamente um pouco de vegetação ripária, do tipo arbóreo-arbustiva, na qual nota-se fortemente a ação antrópica, e em raros lugares atinge os $30 \mathrm{~m}$ de largura preconizados no código florestal.

A rede de drenagem da microbacia tem uma extensão aproximada de $43,1 \mathrm{~km}$, quando são considerados os cursos e calhas de todos os aqüíferos que contribuem para o córrego São Joaquim e seus afluentes. Acatando a legislação vigente, são consideradas matas de preservação permanente aquelas situadas nas áreas que margeiam, em até $30 \mathrm{~m}$, cursos com a largura do córrego São Joaquim, cuja microbacia deveria ter uma área de 258,54ha coberta por mata ripária, de acordo com o estudo cartográfico realizado (Figura 10).

O levantamento mostrou também a existência de 109,20ha com mata ripária e a necessidade de recomposição de mais 149,30ha às margens de cursos d'água da microbacia. Para o cálculo dos hectares a serem recuperados por unidade produtiva, considerou-se o comprimento da margem (em metro) multiplicado por $30 \mathrm{~m}$ (um lado) ou 60m (ambas as margens). Das 28 propriedades detalhadas no estudo, apenas uma não tem curso d'água e portanto não apresenta ou necessita recompor a mata ripária. Nas demais, a maioria ainda tem parte da mata ripária preservada, pois em apenas 6 propriedades a necessidạde de recomposição é total, Tabela 13. 


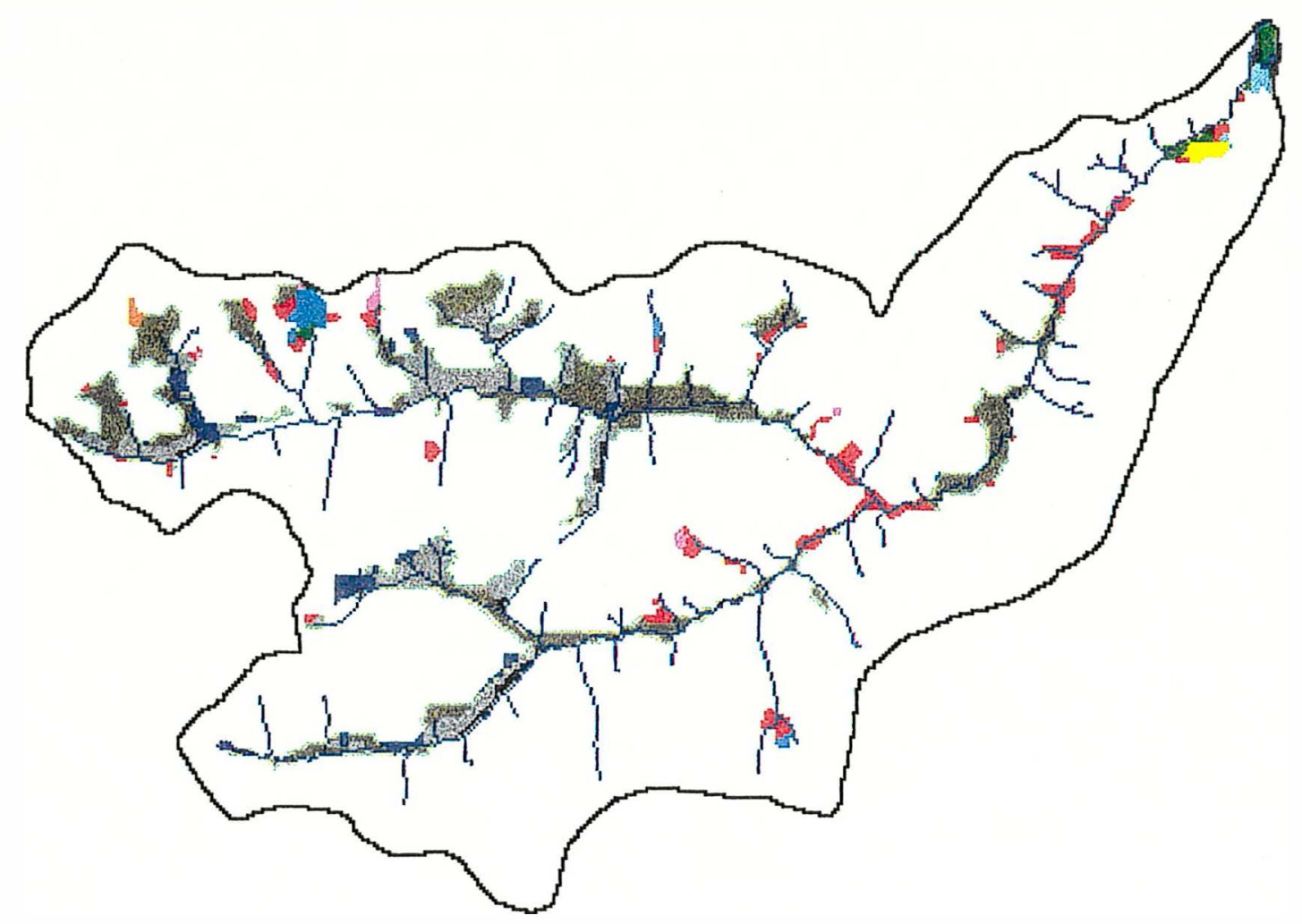

Classe de Capacidade de Uso $\left({ }^{1}\right)$

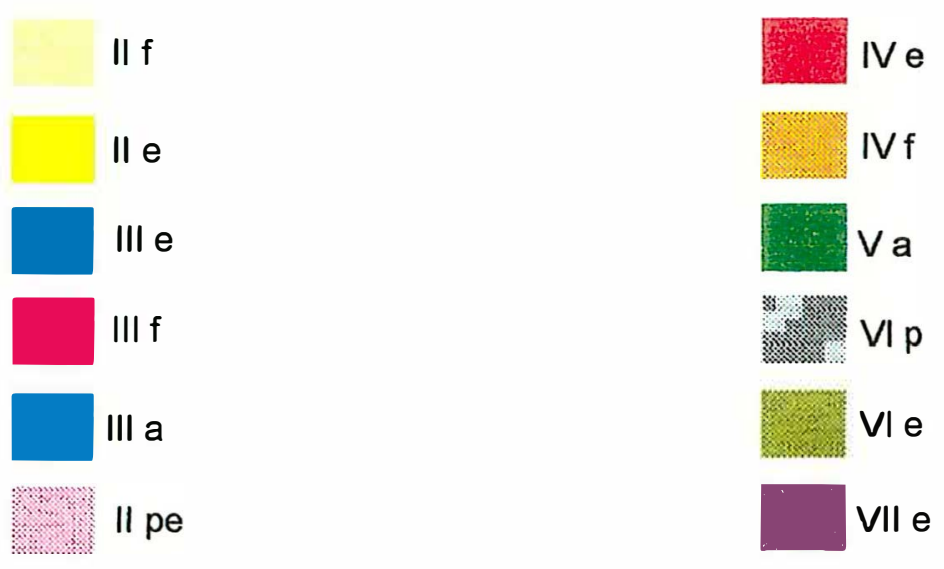

Figura 10. Distribuição da área ocupada com vegetação natural, segundo a classe de capacidade de uso, Microbacia do Córrego São Joaquim, Pirassununga, S.P. 1994

$\left({ }^{1}\right)$ Restrição: fertilidade (f), erosão (e), drenagem (a), profundidade (p) e pedregosidade (pe). Fonte: Elaborado a partir de dados da Seção de Fotointerpretação do IAC/SAA. 
Tabela 13. Estimativa da área indicada para recomposição da mata ripária, microbacia do córrego São Joaquim Pirassununga, SP, 1994

\begin{tabular}{|c|c|c|c|c|c|c|c|}
\hline \multirow{2}{*}{$\begin{array}{c}\text { Unidade } \\
\text { Produtiva }\end{array}$} & \multicolumn{2}{|c|}{ Comp_margem(s)_ } & \multicolumn{3}{|c|}{ recomposição } & \multicolumn{2}{|c|}{ mataripácia } \\
\hline & 1 lado $\left(^{*}\right)$ & 2 lados & 1 lado & 2 lados & total & existente & complementa \\
\hline$\left(n^{0}\right)$ & (m) & (m) & (ha) & (ha) & (ha) & (ha) & (ha) \\
\hline 6 & 390 & - & 1,17 & - & 1,17 & - & 1,17 \\
\hline 8 & 350 & - & 1,05 & - & 1,05 & - & 1,05 \\
\hline 11 & 420 & - & 1,26 & - & 1,26 & - & 1,26 \\
\hline 14 & 470 & 200 & 1,41 & 1,20 & 2,61 & 1,50 & 1,11 \\
\hline 15 & 600 & 400 & 1,80 & 2,40 & 4,20 & 2,85 & 1,35 \\
\hline 16 & 630 & 200 & 1,89 & 1,20 & 3,09 & 1,29 & 1,80 \\
\hline 27 & 400 & - & 1,20 & - & 1,20 & 0,12 & 1,08 \\
\hline 28 & 150 & - & 0,45 & - & 0,45 & - & 0,45 \\
\hline 29 & - & - & - & _ & - & - & - \\
\hline 30 & 1.020 & 660 & 3,06 & 3,96 & 7,02 & 1,50 & 5,52 \\
\hline 32 & 390 & 260 & 1,17 & 1,56 & 2,73 & - & 2,73 \\
\hline 34 & 270 & 680 & 0,81 & 4,08 & 4,89 & 0,70 & 4,19 \\
\hline 35 & 1.170 & 2.120 & 3,51 & 12,72 & 16,23 & 1,26 & 14,97 \\
\hline 39 & 740 & 120 & 2,22 & 0,72 & 2,94 & 2,01 & 0,93 \\
\hline 42 & 1.700 & 900 & 5,10 & 5,40 & 10,50 & 0,81 & 9,69 \\
\hline 43 & 2.540 & 2.300 & 7,62 & 13,80 & 21,42 & 10,32 & 11,10 \\
\hline 44 & 1.500 & 500 & 4,50 & 3,00 & 7,50 & 2,96 & 4,54 \\
\hline 45 & 1.000 & 250 & 3,00 & 1,50 & 4,50 & 1,20 & 3,30 \\
\hline 51 & 2.100 & 570 & 6,30 & 3,42 & 9,72 & 7,74 & 1,98 \\
\hline 52 & 2.350 & 1.200 & 7,05 & 7,20 & 14,25 & 10,05 & 4,20 \\
\hline 54 & 1.800 & 600 & 5,40 & 3,60 & 9,00 & 2,25 & 6,75 \\
\hline 55 & 460 & 460 & 1,38 & 2,76 & 4,14 & 0,18 & 3,96 \\
\hline 58 & 2.400 & 1.000 & 7,20 & 6,00 & 13,20 & 6,60 & 6,60 \\
\hline 59 & 2.400 & 1.700 & 7,20 & 10,20 & 17,40 & 7,50 & 9,90 \\
\hline 60 & 1.700 & 360 & 5,10 & 2,16 & 7,26 & 2,85 & 4,41 \\
\hline 61 & 7.250 & 5.300 & 21,75 & 31,80 & 53,55 & 26,40 & 27,15 \\
\hline 62 & 280 & - & 0,84 & - & 0,84 & 0,26 & 0,58 \\
\hline 64 & 500 & 380 & 1,50 & 2,28 & 3,78 & 3,00 & 0,78 \\
\hline 72 & 3.300 & 2.750 & 9,90 & 16,50 & 26,40 & 14,86 & 11,54 \\
\hline 73 & 450 & 40 & 1,35 & 0,24 & 1,59 & 1,02 & 0,57 \\
\hline 75 & 850 & 350 & 2,55 & 2,10 & 4,65 & - & 4,65 \\
\hline Total & 39.580 & 23.300 & 118,74 & 139,80 & 258,54 & 109,23 & 149,31 \\
\hline
\end{tabular}

Fonte: Dados da pesquisa.

$\left(^{*}\right)$ Nos casos onde a divisa está superposta à drenagem.

\subsubsection{Medidas mitigadoras e seus beneficios}

Descritos os principais impactos ambientais causados pelas explorações agropecuárias à área da microbacia do córrego São Joaquim, o passo seguinte consistiu em relacionar as medidas saneadoras que deveriam ser adotadas, através de uma série de entrevistas a espeçialistas em conservação e manejo do solo do 
Instituto Agronômico de Campinas (IAC) e da Coordenadoria de Assistência Técnica Integral (CATI), órgãos da Secretaria de Agricultura e Abastecimento.

Há unanimidade técnica em apontar o desrespeito à classe de capacidade de uso como o principal problema a ser ajustado. É fundamental racionalizar o manejo do solo através da observação da classe de capacidade de uso para permitir a manutenção de sua capacidade produtiva. Tal medida, somada ao cumprimento da legislação florestal, implicará na alteração da distribuição das atividades agropecuárias na microbacia, conforme a Tabela 14. A substituição baseouse na premissa, já citada anteriormente, de que ao adequar-se a ocupação à classe de capacidade de uso, não seriam sugeridas atividades de produção não tradicionais na microbacia. Admite-se que a introdução de explorações inovadoras implicaria em estudos de potencialidade de mercado, bem como de análises mais detalhadas sobre a capacidade de gerenciamento e condução pelo recurso humano disponível.

Tabela 14. Adequação às classes de capacidade de uso das glebas da microbacia do córrego São Joaquim, em hectare, Pirassununga, SP

\begin{tabular}{lccc}
\hline Uso & Atual & Proposto & Variação \\
\hline Citros & 660,96 & 505,08 & $-155,88$ \\
Cana-de-açúcar & 834,79 & 548,59 & $-286,20$ \\
Culturas anuais & 420,12 & 246,60 & $-159,52$ \\
Pastagens & 621,36 & $1.087,65$ & $+466,29$ \\
Reflorestamento & 47,16 & 47,16 & - \\
Matas naturais & 460,08 & 609,39 & $+149,31$ \\
\hline Total & $3.044,47$ & $3.044,4747$ & - \\
\hline
\end{tabular}

Fonte: Dados da pesquisa.

Como pode ser notado, houve expressivas reduções nas áreas ocupadas com as culturas de citros, cana-de-açúcar e demais culturas anuais, respectivamente de $155,88 \mathrm{ha}, 286,20 \mathrm{ha} \mathrm{e} 159,52 \mathrm{ha}$. A redução foi fruto da adequação imposta pelas características restritivas dessas áreas, apenas passiveis de uso com 
pastagens, reflorestamentos ou vegetações nativas para refúgio de vida silvestre. Quando não destinadas à recomposição da mata ripária $\left(1^{\mathrm{a}}\right.$ opção), e conforme o pressuposto, entre pastagens e reflorestamento, essas áreas foram incorporadas à área com pastagens. Desta maneira, optou-se pela utilização mais acessível aos proprietários, admitindo-se que esta seria a destinação pretendida, pois como essa atividade está presente em quase $70 \%$ das unidades produtivas, parece aceitável, portanto, que o pasto seja facilmente aproveitado pelo proprietário ou por unidades vizinhas. Entretanto, para alguns técnicos, o correto seria adotar o reflorestamento, uso mais em acordo com a vocação, pois as restrições de manejo do pasto e conseqüente baixa capacidade de suporte, levam a uma pecuária de baixos resultados, os quais, muito provavelmente superados pelos possiveis rendimentos com a exploração florestal.

Já o aumento na área com matas naturais deveu-se unicamente à incorporação das áreas onde deverá ser recomposta a mata ripária, atendendo a legislação vigente, e importante como medida mitigadora.

Há uma série de recomendações genéricas que devem ser observadas para as áreas com exploração agropecuária (Apêndice 1). Entre elas pode-se destacar a realização de análises de solo para permitir uma adubação correta, bem como da calagem em quantidade adequada. O plantio em nivel e o uso de escarificador em substituição aos arados são recomendações de ordem mecânica que buscam manter melhor estrutura para a camada superficial e torná-la mais resistente à erosão. Especificamente para as culturas anuais, é recomendada a incorporação dos restos de cultura com uso de grade niveladora, contrariamente à agressiva prática de queima.

O terraceamento também deverá ser empregado em todas as áreas cultivadas com cana e com culturas anuais e estimada a sua adoção à base de $100 \mathrm{~m}$ por hectare de classe I; $150 \mathrm{~m}$ por hectare da classe II; $200 \mathrm{~m}$ por hectare da classe III e 400m por hectare da classe IV. Para o caso das classes de capacidade de uso da microbacia do córrego São Joaquim, com citros e com pastagens, não foi recomendado o investimento em terraços.

Para as áreas ocupadas com citros, a recomendação técnica para controle da erosão é o manejo da cobertura, mantendo-a totalmente roçada durante o verão. Usualmente o produtor procẹde à capina (manual ou química) e/ou ao 
coroamento das plantas para manter a cultura livre da competição de invasoras. Todavia, dado o potencial natural de erosão, recomenda-se a não eliminação total das invasoras, mantendo uma concorrência controlada por roçadas, de forma a que o solo fique coberto e mais protegido. Esta prática provoca uma redução ao fator " $\mathrm{C}$ " em $50 \%$.

As causas de degradação das áreas com pastagens estão relacionadas com manejo inadequado, onde a prática mais comum é a densidade de suporte acima de sua capacidade, sem a devida compensação de limpeza bem efetuada, acompanhada de adubação e calagem. Ressalte-se também que a retirada da mata ripária, aliada a ausência de bebedouros adequados, tornam os aqüíferos fonte de água para o gado, e os animais transformam-se em fortes agentes erosivos, deterioram as margens, bem como provocam sulcos perpendiculares ao ribeirão que poderão iniciar voçorocas (Figura 11).

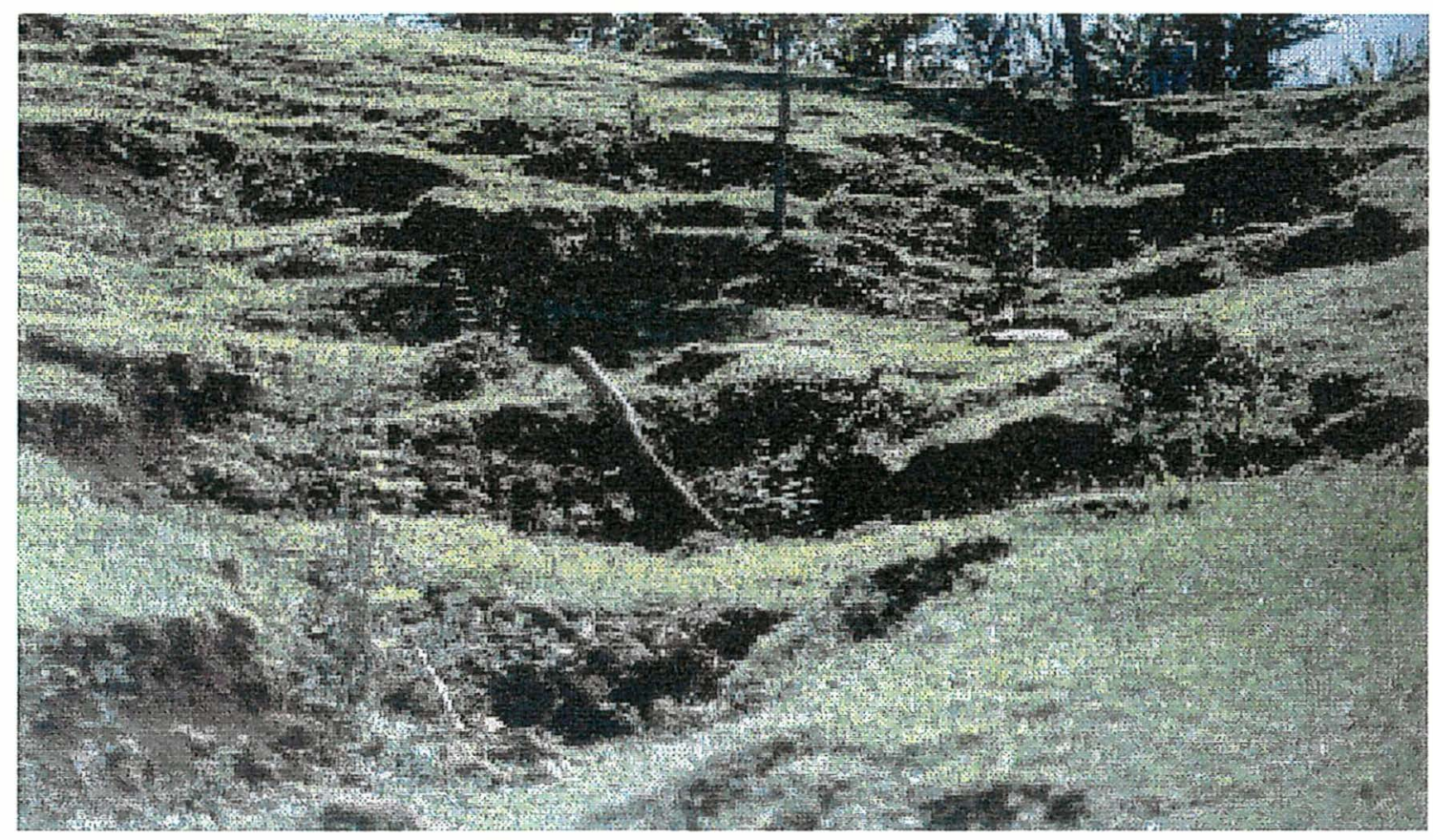

Figura 11. Área de classe capacidade de VII com uso inadequado de pastagem, com início de processo de voçoroca. UP 58, microbacia do córrego São Joaquim, Pirassununga, SP, 1997. 
Assim sendo, para as pastagens, além das medidas usuais de limpeza e condução adequada das capineiras, adota-se as recomendações de divisão dos pastos e colocação de bebedouros para preservar a mata ripária, pois há muito pasto nas cabeceiras da microbacia (Figura 12).

Finalmente, procura-se estabelecer os benefícios advindos da adequação ambiental da agricultura praticada na microbacia do córrego São Joaquim, através da adoção das práticas acima enumeradas. É de se esperar que algumas medidas, como plantio direto, incorporação de restos de cultura e divisão e manejo adequado de pastos, possam não ser imediatamente usadas em $100 \%$ das glebas, dado o atual estoque de máquinas. Desta forma, embora conscientes do caráter subjetivo, optou-se pela premissa de uma taxa de adoção de $50 \%$ em cada ano, para efeito de cálculo das estimativas necessárias.

Assim como os danos causados pela inadequação de uso, também os benefícios são imponderáveis, ou de difícil aferição. É o caso da possibilidade de recuperação da fauna, e conseqüentemente preservação da biodiversidade, aqui não avaliados. Desta maneira, pode-se resumir em três os principais feitos das medidas sugeridas: primeiramente, a diminuição da perda de solo e suas conseqüências; em segundo, o aumento da infiltração de chuvas no solo, alterando o ciclo hidrológico da microbacia; e, por fim, a conjugação dos efeitos benéficos dos dois primeiros implicam no aumento da capacidade produtiva das glebas.

As medidas sugeridas modificam o valor estimado para a perda de solo influindo diretamente nos valores do parâmetro " $\mathrm{C}$ ", e no componente topográfico - LS - da EUPS. A adequação, mediante prática de manejo do solo, reduz os valores de "C", de 0,087 para 0,044 nas áreas com citros; de 0,107 para 0,08 para a cana-deaçúcar; do valor médio de 0,177 para 0,089 , no caso das demais culturas anuais da 


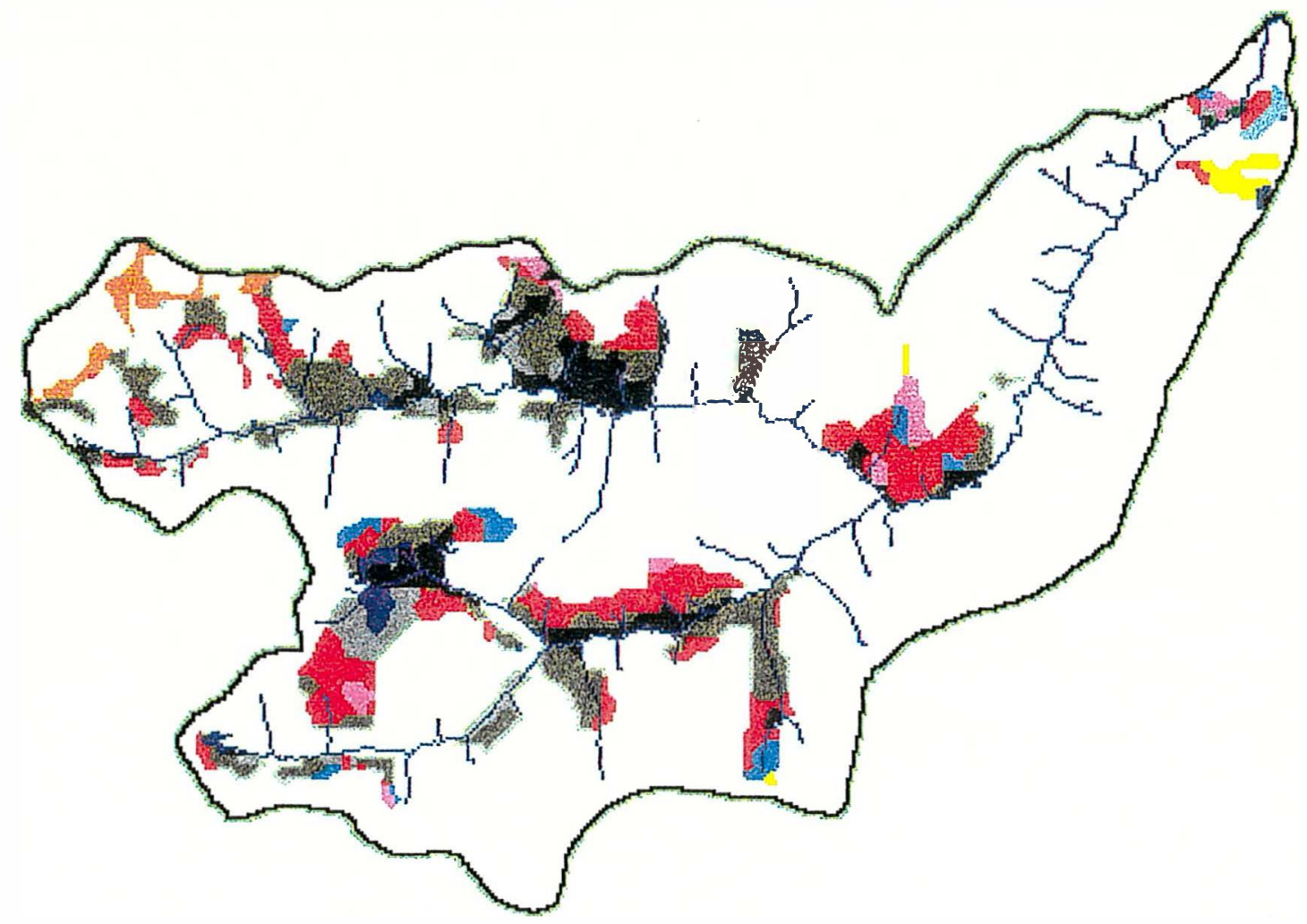

\section{Classe de Capacidade de Uso ( $\left.{ }^{1}\right)$}

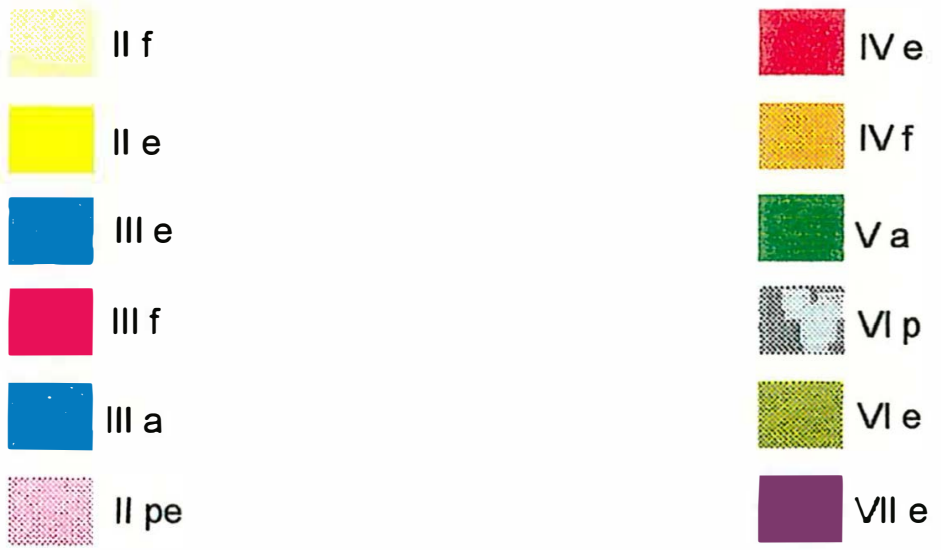

Figura 12. Distribuição da área ocupada com pastagens, segundo a classe de capacidade de uso, Microbacia de São Joaquim, Pirassununga, S.P. 1994.

( $\left.{ }^{1}\right)$ Restrição: fertilidade (f), erosão (e), drenagem (a), profundidade (p) e pedregosidade (pe). Fonte: Elaborado a partir de dados da Seção de Fotointerpretação do IAC/SAA. 
microbacia e de 0,01 para 0,008 para as áreas com pastagens; o valor de "C" médio para a microbacia, ponderado pela área, fica reduzido de 0,076 para 0,0333.

Também se reduz o indicador da influência da topografia (LS), pelo fato da construção de terraços fragmentar o comprimento das rampas: seu valor passa de 3,2374 para 1,84. Esse número sofre ainda o ajuste pelo fator " $P$ ", pois com as práticas utilizadas há uma redução de 1 para 0,78 . O conjunto de fatores - LSP - fica com o valor de 1,44 .

Dessa forma, a perda de solo, considerando a adequação ambiental e o manejo do solo, atinge um valor médio inferior ao limite de tolerância, cuja estimativa, através da EUPS passa a ser de:

$$
A=\operatorname{LSP} \times \mathrm{X} \quad \mathrm{K} \quad \mathrm{C} \times \mathrm{R}
$$

$$
A=1,44 \times 0,285 \times 0,0333 \times 7.103=9,71 \text { tha }
$$

Quanto à variação no regime hidrológico, as mudanças no manejo do solo, somadas às áreas com recuperação de mata ripária, proporcionarão uma redução na enxurrada, pela maior infiltração.

Segundo Bertoni \& Lombardi Neto (1990), é possivel estimar o volume atual de enxurradas conhecendo-se a porcentagem de chuva que escorre em cada tipo de exploração do solo (escorrimento médio), e a precipitação média anual de 1.384mm, período 1947-1988, obtida pelo posto de Pirassununga do Departamento de Águas e Energia Elétrica (DAEE).

A estimativa do total anual de água da chuva que escorre por enxurradas na microbacia em estudo é de 1.127.525,15m3 (Tabela 15), que, quando mal conduzidos, podem causar sérios danos 
TABELA 15. Estimativa da variação do volume de água escorrida por enxurradas, sem e com adequação às classes de capacidade de uso, microbacia do Córrego São Joaquim, Pirassununga, SP, 1994.

\begin{tabular}{lrrrrr}
\hline Exploração & área & escorrimento & \multicolumn{2}{c}{ enxurrada } \\
\hline Uso atual & (ha) & (\% da chuva) & $\left(\mathrm{m}^{3} / \mathrm{ha}\right)$ & $\left(\mathrm{m}^{3}\right)$ \\
Citros & & & & 152 & $100.465,92$ \\
Cana-de-açúcar & 660,96 & 1,10 & 581 & $485.012,99$ \\
Culturas anuais & 834,79 & 4,20 & 969 & $407.096,28$ \\
Pastagem & 420,12 & 7,00 & 138 & $85.747,68$ \\
Reflorestamento & 621,36 & 1,00 & 97 & $4.574,52$ \\
Vegetação natural & 47,16 & 0,70 & 97 & 44.627 .76$. \\
$\quad$ Total & 460,08 & 0,70 & & $1.127 .525,15$ \\
Com adequação & $3.044,47$ & & & \\
Citros & & 1,10 & 58 & $76.772,16$ \\
Cana-de-açúcar & 505,08 & 4,20 & $518.730,79$ \\
Culturas anuais & 548,59 & 7,00 & 969 & $238.955,40$ \\
Pastagem & 246,60 & 1,00 & 138 & $150.095,70$ \\
Reflorestamento & $1.087,65$ & 0,70 & 97 & $4.574,52$ \\
Vegetação natural & 47,16 & 0,70 & 97 & $59.110,83$ \\
$\quad$ Total & 609,39 & & & $848.239,40$ \\
\hline
\end{tabular}

Fonte: Bertoni \& Lombardi Neto (1990) e dados da pesquisa.

Com a adoção das práticas preconizadas, este volume reduz-se para cerca de 848,2 mil $^{3}$, por ano, devido a maior capacidade de infiltração, permitindo a retenção de água e recarga dos aqüíferos em cerca de $279,3 \mathrm{mil} \mathrm{m}^{3}$, por ano, em média. Esse valor corresponde a quase $25 \%$ do total das enxurradas que ocorrem sem a adequação do uso do solo à respectiva classe de capacidade.

Ressalte-se que a retenção poderá ser ainda ampliada com emprego de técnicas para sua melhoria como, embaciamento e terraceamento, e com o aumento da capacidade de infiltração do solo, através de sua subsolagem e/ou escarificação acompanhada de semi-incorporação dos restos de cultivo.

A adoção das práticas acima mencionadas devem permitir a retenção do volume de água precipitado dentro das glebas, evitando que a formação de enxurradas possam tornar inadequadas as estradas e vias de acesso (Figura 13) 


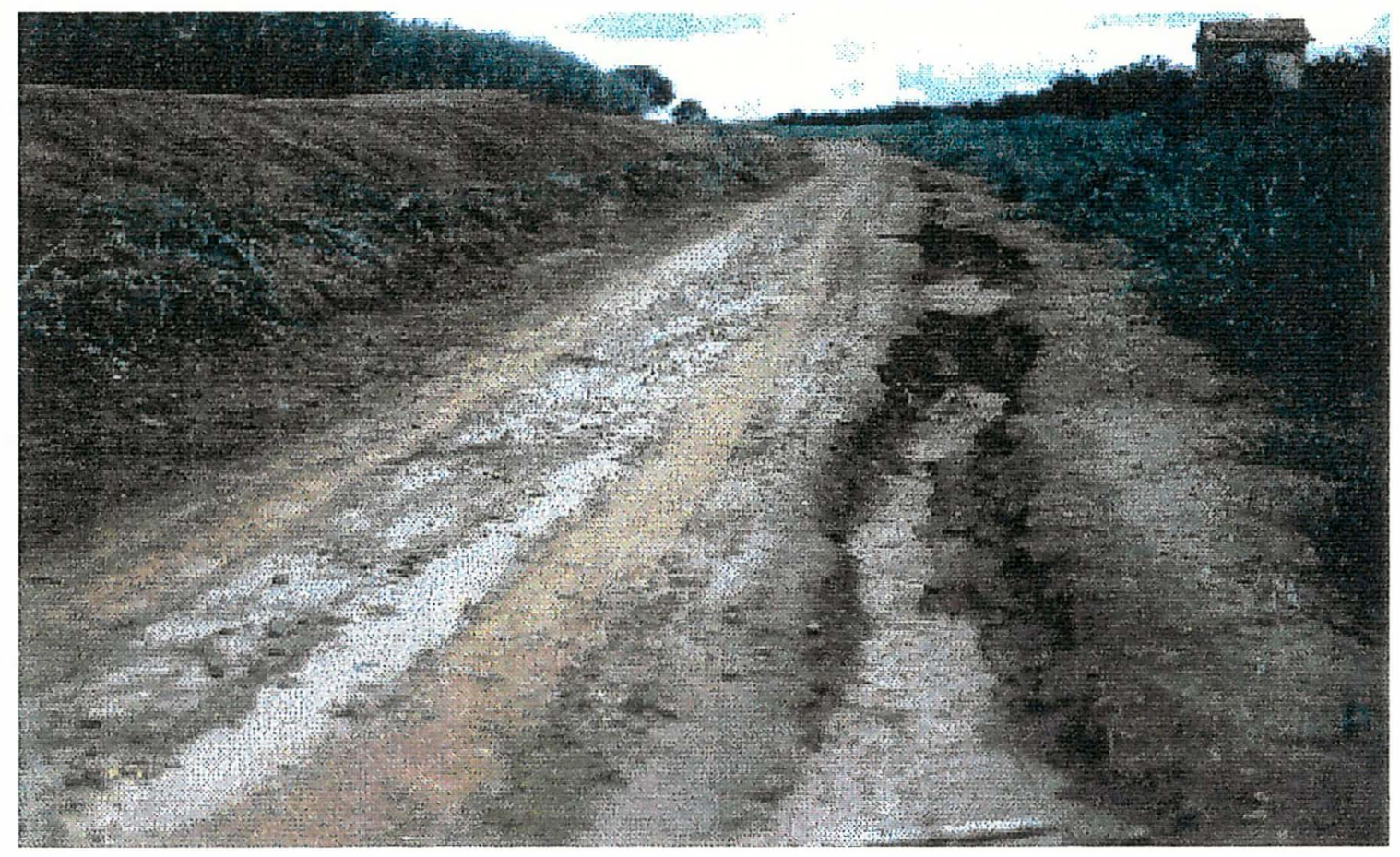

Figura 13. Erosão em sulco provocada por enxurrada mal controlada, microbacia do córrego do São Joaquim, Pirassununga, SP.

Finalmente, os especialistas em conservação e manejo de solo indicaram que com a adoção de técnicas, certamente haverá um ganho na capacidade produtiva das áreas manejadas, tanto pela conjugação dos efeitos em si, como por suas conseqüências, tal como o aumento de matéria orgânica na camada superficial do solo. Porém, não foram encontradas na literatura indicadores representativos desse ganho para as condições edáficas da microbacia, bem como de métodos para estimá-los. Baseados no conhecimento empírico e analisadas as características da microbacia, pesquisadores da Seção de Conservação de Solo e Seção de Fotointerpretação do IAC sugerem o uso de um ganho médio de cerca de $0,5 \%$, ao ano. 


\subsection{Avaliação econômica}

Como já visto, as ações mitigadoras propostas resumem-se, em essência, na observância da classes de capacidade de uso do solo, na recuperação de mata ripária e na contenção de enxurradas, através do terraceamento e de outras práticas conservacionistas. Essas últimas compõem-se de: substituição das arações e gradagens pesadas pela escarificação e semi-incorporação dos restos de cultura, nas áreas em cultivo anual, a divisão dos pastos e a instalação de bebedouros para as áreas de pastagem.

Como já mencionado, com estudos cartográficos baseados nas cartas de tipos de solos e plano-altimétrica, foi possível determinar as áreas ocupadas pelas diferentes culturas, bem como as respectivas classes de declividade e capacidade de uso. Através destes dados foi possivel municiar o aplicativo Farmod ${ }^{13}$ de elementos de cálculos que permitissem a geração dọ fluxos de caixa para os projetos da microbacia como um todo e para as unidades produtivas selecionadas. As matrizes de coeficientes técnicos para as várias atividades consideradas nos projetos, bem como os respectivos orçamentos acham-se explicitados no apêndice 3.

As operações de terraceamento foram projetadas ao custo de $\mathrm{R} \$ 54,00$ por hora-máquina, fornecido pela Companhia de Desenvolvimento Agrícola do Estado de São Paulo (CODASP), que oferece e usualmente executa esse tipo de serviço. A estimativa de despesas para a recomposição de mata ripária foi orçada em cerca de $R \$ 1.485,30$ por hectare, sendo $R \$ 1.199,40$ gastos no primeiro ano e $R \$ 285,90$ no segundo ano, para uma densidade de 1.667 plantas por hectare. Este valor foi obtido em entrevista com técnico da Coordenadoria de Assistência Técnica Integral (CATI) da Secretaria de Agricultura e Abastecimento do Estado de São Paulo ${ }^{14}$ e correspondem a:

\footnotetext{
${ }^{13}$ FARMOD - aplicativo de autoria de TEMPLE et al., sob os auspicios do Banco Mundial, em cooperação da FAO e IFAD. Versão 4.02 , abril de 1.996. Copyright (c) 1992,93,94 BIRD.

${ }^{14} \mathrm{O}$ entrevistado foi o Engenheiro Agrônomo Jorge Belix dos Campos, da Casa da Agricultura de Pedreira, SP, então Presidente da Associação Mata Ciliar.
} 
- no $1^{\circ}$ ano: $R \$ 664,00$, com mudas de essências nativas; $R \$ 77,80$ com fertilizantes e formicidas e $R \$ 457,60$, com mão-de-obra.

- no $2^{\circ}$ ano: $R \$ 56,00$, com mudas de essências nativas; $R \$ 49,50$, com fertilizantes e formicidas e $R \$ 180,40$, com mão-de-obra.

As despesas acima mencionadas representam, para a microbacia como um todo, um investimento de cerca de $R \$ 352$ mil; destes, cerca de $R \$ 309,4$ mil é realizado no primeiro ano, e o restante, $R \$ 42,6$ mil, no segundo ano.

Como retorno aos investimentos tem-se a reversão na tendência de queda da produtividade, sendo esperado um ganho de $0,5 \%$, ao ano, como resultante da melhoria das condições físicas, químicas e biológicas do solo. Observe-se que o desembolso mais expressivo ocorrerá com as operações de terraceamento, na divisão de pastos e na construção de bebedouros; estas são as ações que revertem efetivamente no aumento da produtividade física das áreas trabalhadas, pois a recomposição das matas trará mais retorno para o sistema ambiental como um todo. O custo de implantação destas medidas representa cerca de $37 \%$ do total de investimento, sendo que a maior parte correspondente à recomposição de mata ripária (63\%), a qual, com já mencionado, não produz retorno financeiro direto para as unidade produtiva da microbacia.

Assim sendo, para os $3.044,47$ ha, estima-se um retorno de cerca de $\mathrm{R} \$ 128,4$ mil anual, devido à adequação ambiental, parte dos quais refere-se aos benefícios decorrentes da diminuição de perda de solo e conseqüente economia em nutrientes em toda a área. As quantidades de nutrientes que deixarão de ser arrastadas, conforme exposto no item 3.1.3, multiplicadas pelos respectivos valores de mercado, permitem estimar uma economia de cerca de $\mathrm{R} \$ 104,8$ mil, por ano. A parte restante, de $\mathrm{R} \$ 23,6$ mil, diz respeito à externalidade positiva gerada pela redução nas despesas com o tratamento da água e com a dragagem do córrego, para o sistema urbano de captação da água, segundo dados fornecidos pelo Serviço de Águas e Esgoto de Pirassununga (SAEP).

Com o ajuste do tipo de atividade agropecuária na ocupação das glebas, alinhando-as com as respectivas classes de capacidade de uso do solo, ocorre 
uma alteração na proporção entre as áreas com atividades geradoras de renda (utilizadas com citros, cana-de-açúcar, soja, milho, algodão e pecuária) e aquelas destinadas à áreas de preservação ambiental (com recomposição florestal). Estas alterações determinam a performance financeira do projeto, explicitada pelos níveis dos indicadores de análise de projetos, Taxa Interna de Retorno (TIR) e Valor Líquido Presente (VLP). Com auxílio do aplicativo "Farmod" foram gerados valores incrementais para os fluxos de caixa, taxas internas de retorno e valores líquidos presente, ou seja, ao projeto representando o uso atual é sobreposto ao alternativo e as diferenças propiciam uma análise baseada em valores incrementais. Foi estudada a adequação da microbacia como um todo, e de 28 unidades produtivas selecionadas, cuja soma das áreas perfazem 2.306,63ha, ou seja, 75,8\% da microbacia (Figura 14).

Considerando o projeto de reorganização da área total da microbacia hidrográfica, onde se propõe alterar o uso em 523,30 ha $(17,20 \%$ da área total), obtémse uma taxa interna de retorno de $10,86 \%$ (Tabela 16). O fluxo de caixa incremental apresenta, ao final do horizonte de 20 anos, o valor total de $R \$ 3.827,30$, que descontado à uma taxa de $6 \%$ a.a. (custo de oportunidade do capital), significará um valor presente atualizado de $\mathrm{R} \$ 930,55$. O fluxo de caixa permite também estabelecer um "payback" de 16 anos, ou seja, o fluxxo líqüido descontado à $6 \%$ ao ano possibilitará uma amortização total do investimento decorridos 16 anos da sua implantação.

Quando analisadas as 28 Unidades Produtivas (UP), evidencia-se uma extrema variabilidade de taxas internas de retorno, com uma amplitude que cresce desde valores indefinidos para a UP 39 (por fluxo líquido negativo durante os 20 anos) e negativos de $-4,97 \%$ para a UP 43 , até taxas elevadas como de $62,05 \%$ para a UP 51. Esta variação decorre das diferentes alterações dos projetos, podendo-se inferir que as baixas taxas acham-se associadas a porcentagens maiores de alteração no sistema produtivo original, e, principalmente, quando esta alteração refere-se a diminuições em áreas utilizadas com as culturas mais rentáveis como, citros, algodão e cana-de-açúcar, e que passam a ser ocupadas por mata ripária ou pastagem. É possivel observar que não há correlação entre os valores das taxas e a área total da UP, com propriedades grandes e pequenas apresentando tanto altas como baixas taxas. Todavia, quando o percentual de mudança provocada pela adequação é significativo e a ele está associado uma redução em citros, tem-se as mais baixas 


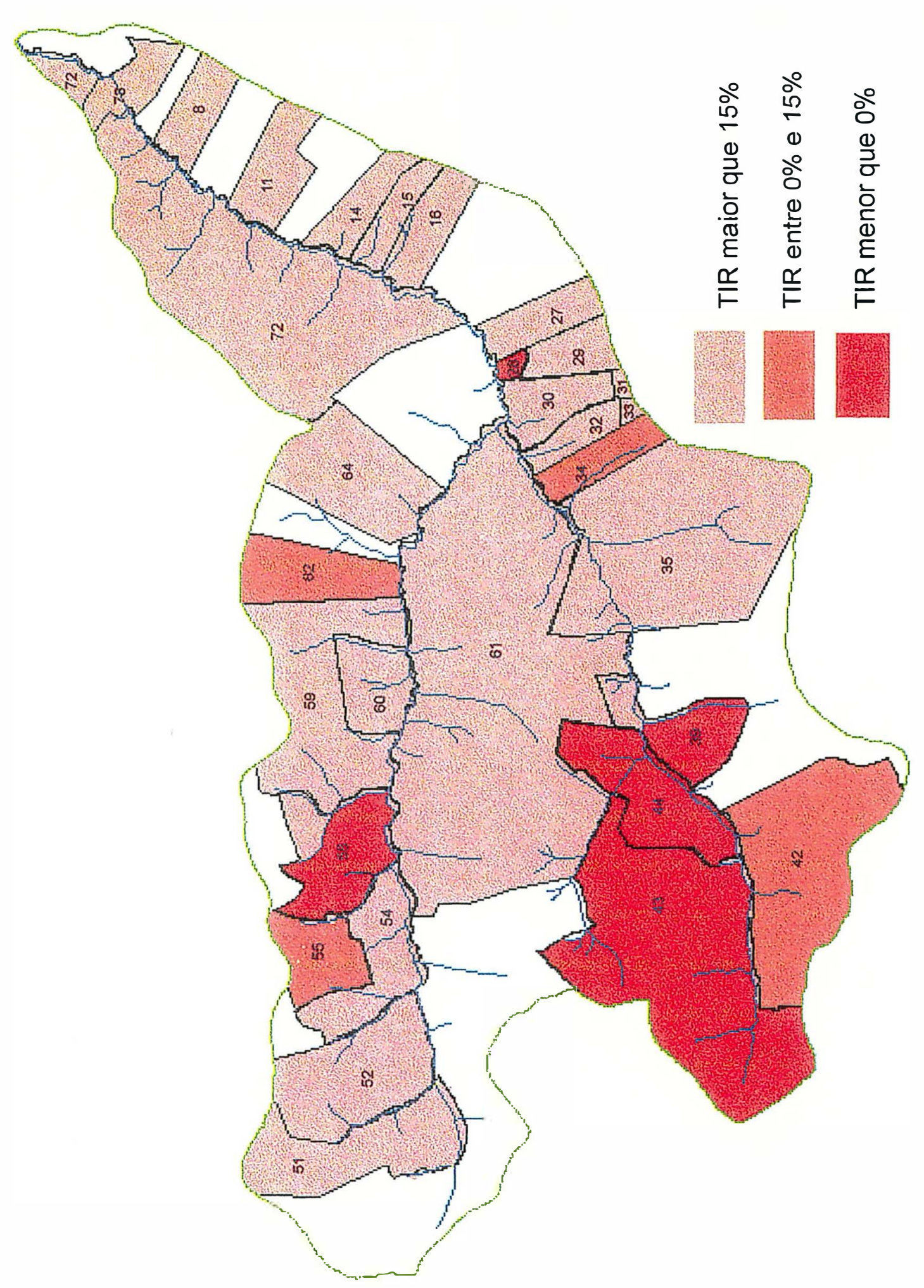

के

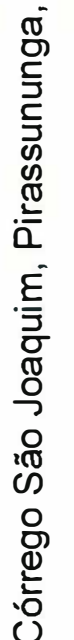
응

\begin{tabular}{l}
$\frac{\pi}{\mathcal{O}}$ \\
$\frac{\pi}{0}$ \\
$\frac{0}{0}$ \\
$\frac{0}{\mathcal{O}}$ \\
\hline
\end{tabular}

ํํำ 


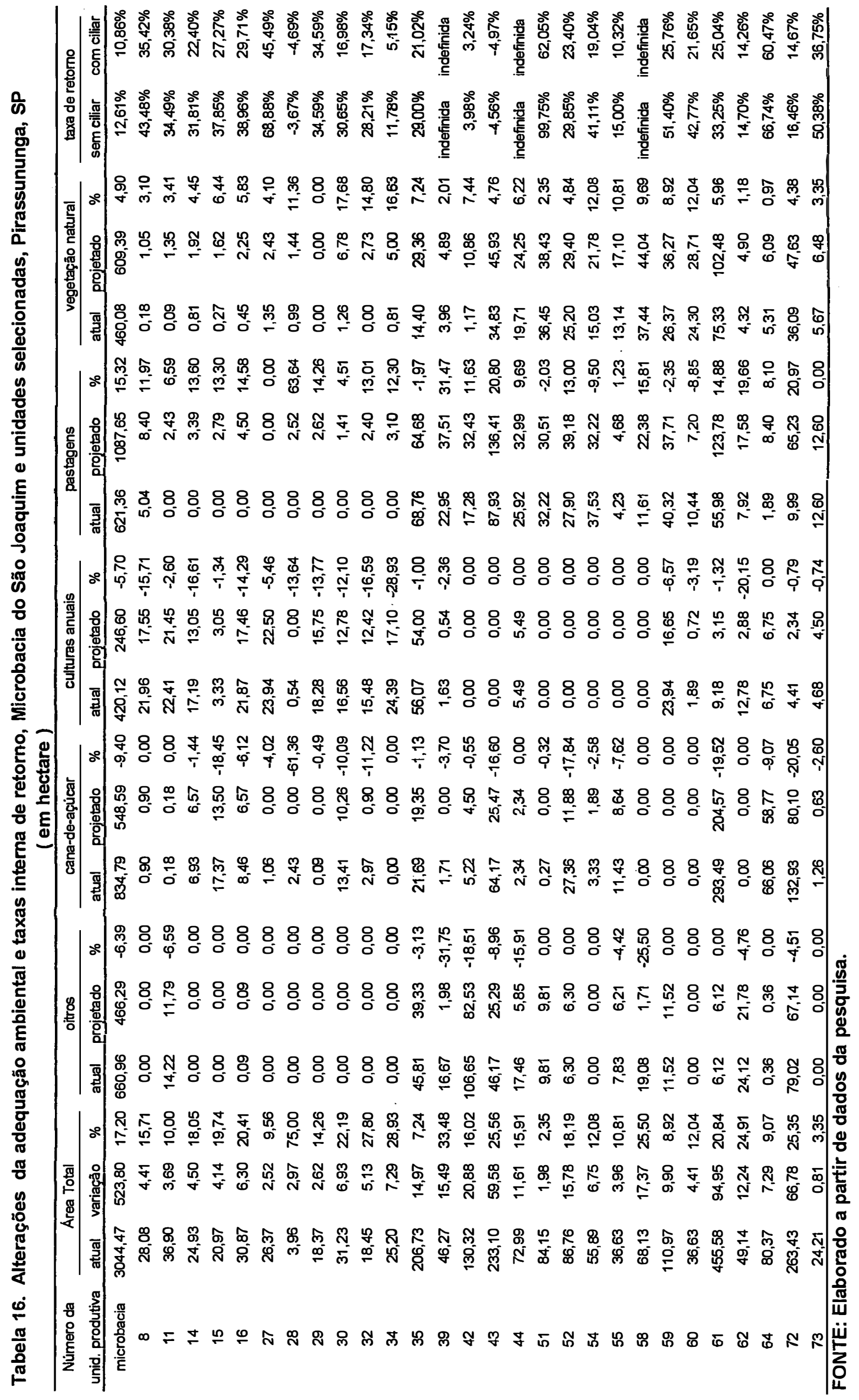


taxas, negativas e/ou com fluxo líquido incremental totalmente negativo, e que portanto, caracteriza uma situação onde a taxa interna de retorno não se define como no caso das UPs 39, 44 e 58 (Tabela 17).

Considerando-se um custo de oportunidade do capital de $6 \%$ ao ano, verificou-se que a maioria dos projetos (75\%) coloca-se como atraente, pois os respectivos fluxos de caixa descontados à taxa proposta resultariam em VLP positivos. Destaque-se que mais da metade dos projetos apresentam TIR superiores a $20 \%$.

Em um segundo enfoque, procurou-se avaliar o peso da recuperação da mata ripária no custo total do ajuste ambiental para a microbacia e para as UPs. Tal preocupação deve-se ao fato de que a maior parcela do benefício da recomposição florestal é usufruída fora das unidades da própria microbacia. Assim sendo, verificouse como se comportam as TIRs dos projetos, quando destes são retirados os custos de implantação de mata ripária, e a possibilidade de reverter aqueles não atrativos economicamente, de maneira a permitir um tratamento mais abrangente a um programa ambiental para boa parte das UPs da microbacia. Os resultados demonstraram expressivo ganho para todas as taxas, contudo, não se modificou a situação daquelas que apresentaram uma TIR negativa ou indefinida. Isto mostra que embora o custo de recomposição da mata ripária seja proporcionalmente elevado em relação às outras medidas mitigadoras, esta não é uma ação determinante quanto à viabilidade econômica (Tabela 18).

Finalizando, convém salientar que quando descontados à taxa de $6 \%$ ao ano, os fluxos de caixa dos projetos das UPs resultam em paybacks que giram em torno de 7 a 8 anos; estes prazos deverão ser observados caso venham a ser implantados programas de financiamento ao proprietário. Nos projetos onde a responsabilidade financeira sobre a recuperação da mata ripária foi tirada do proprietário, o tempo para repor as despesas do ajuste ambiental se concentra entre 5 a 7 anos. 


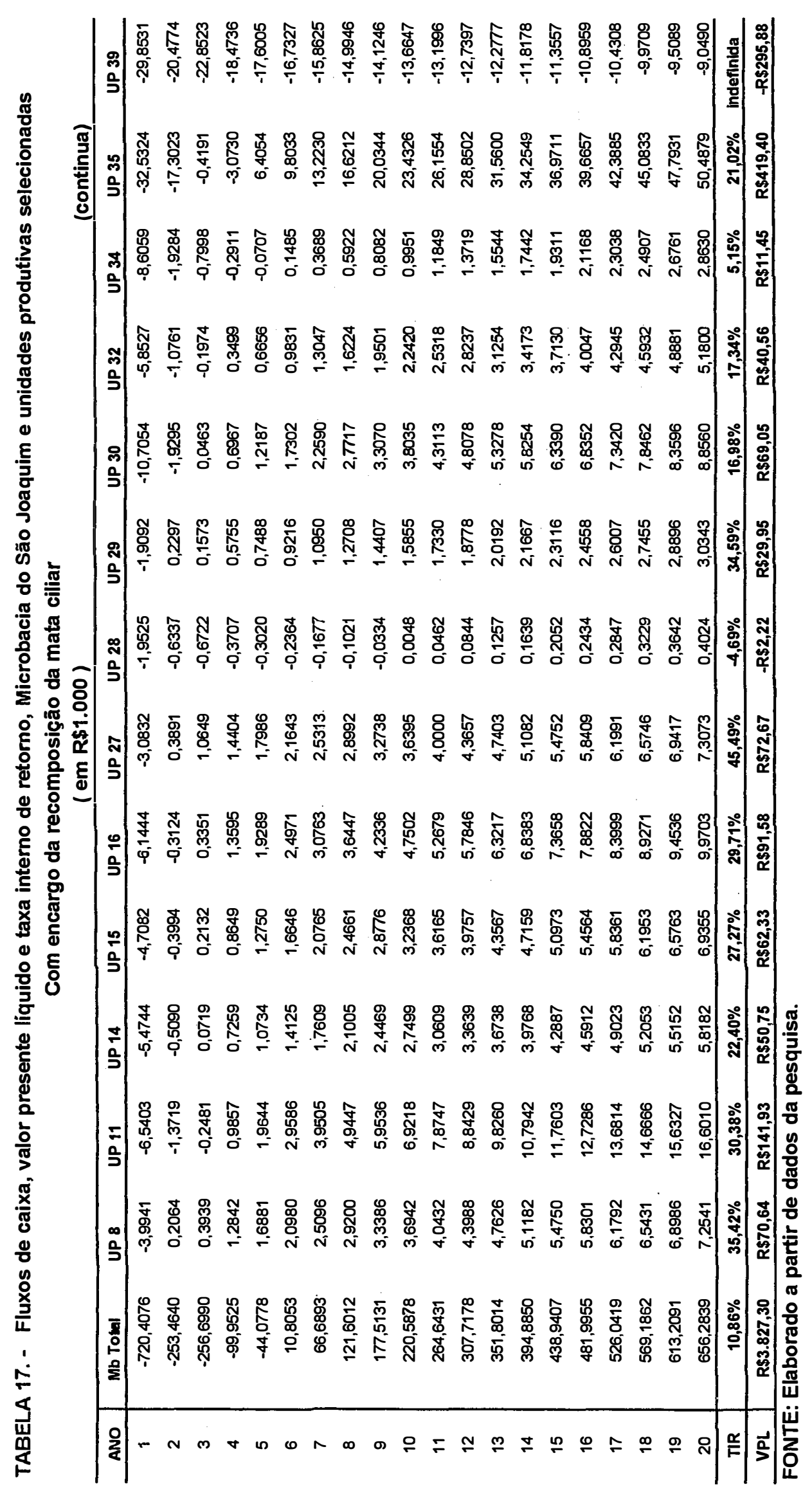




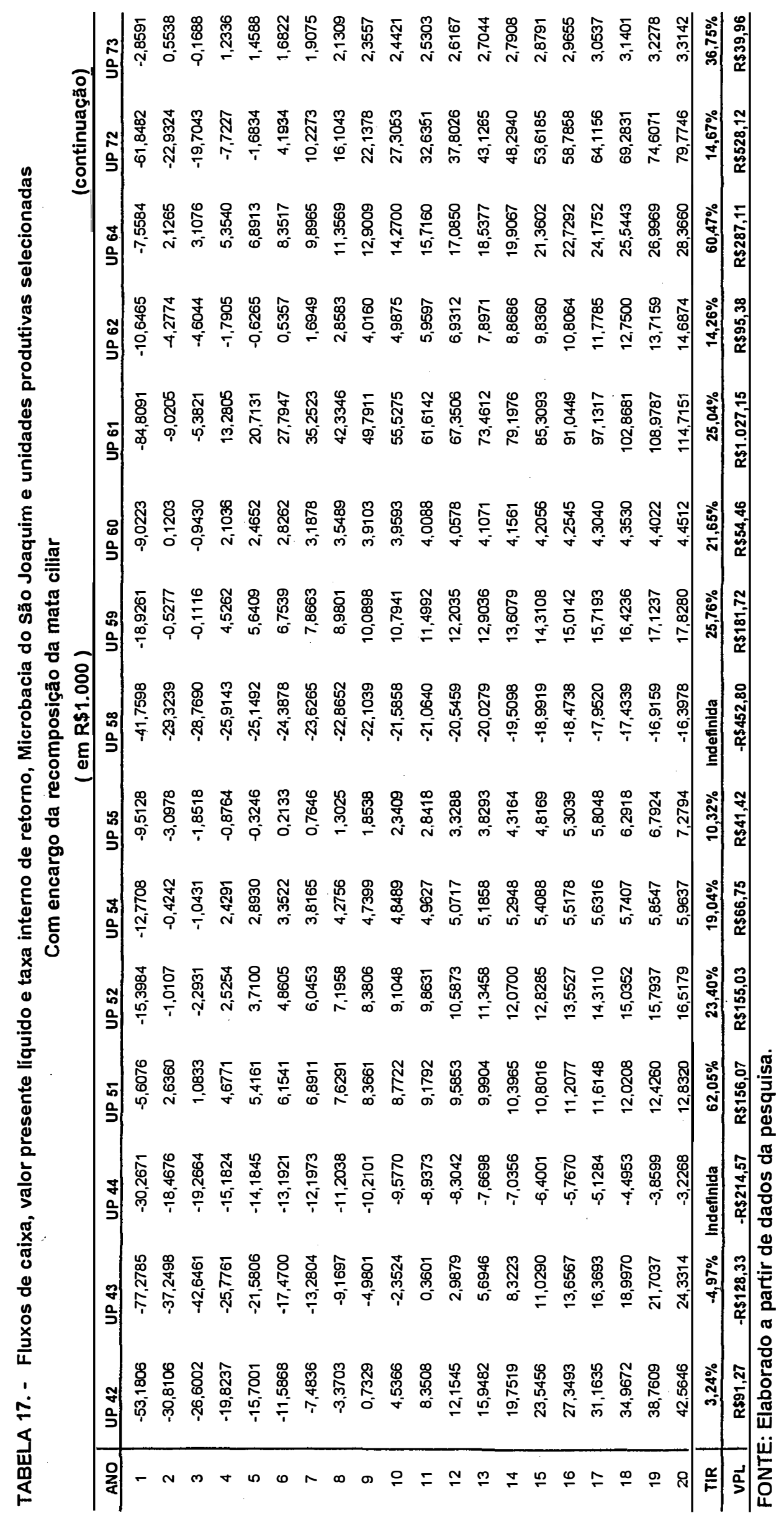

92 


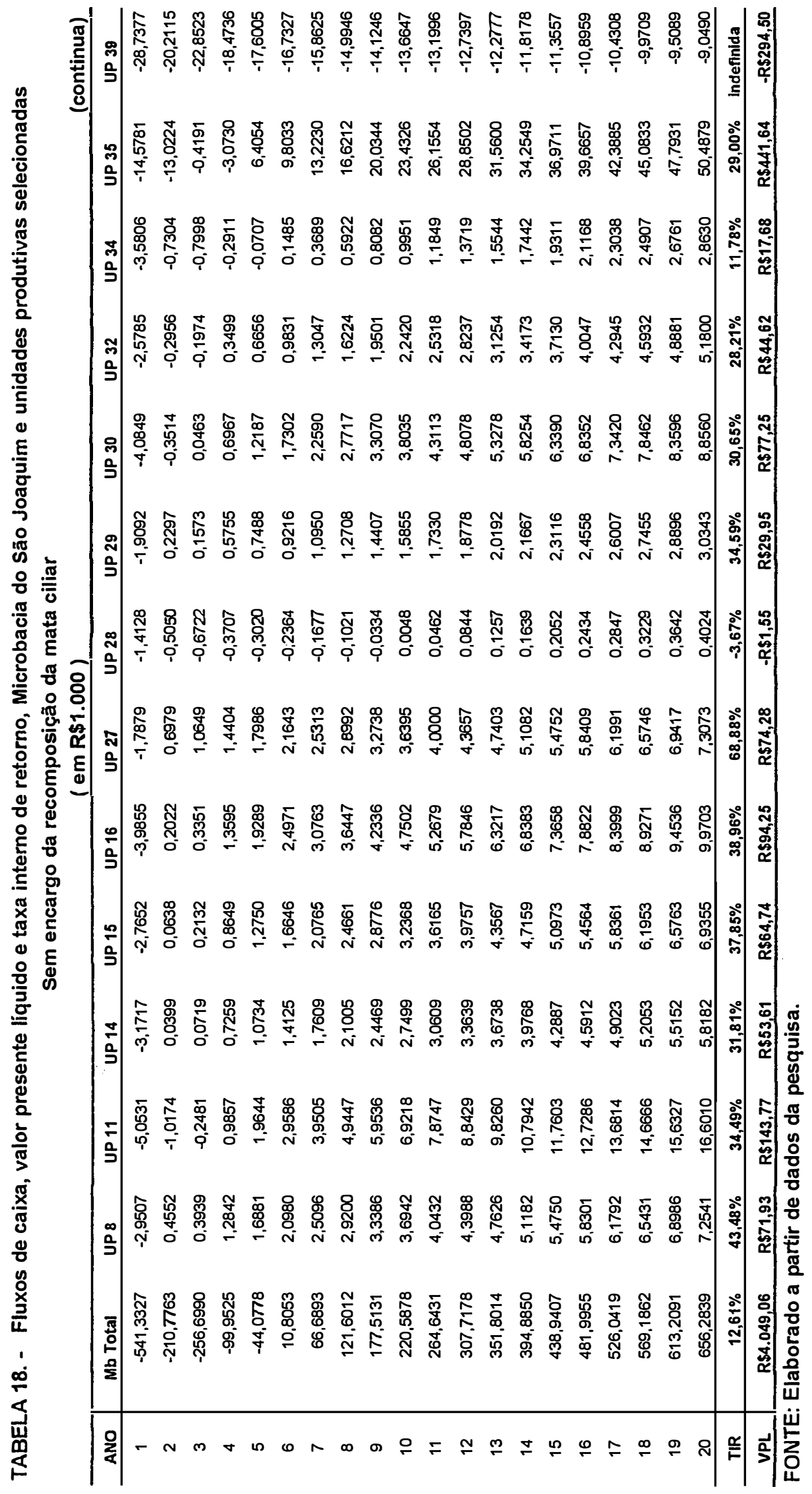




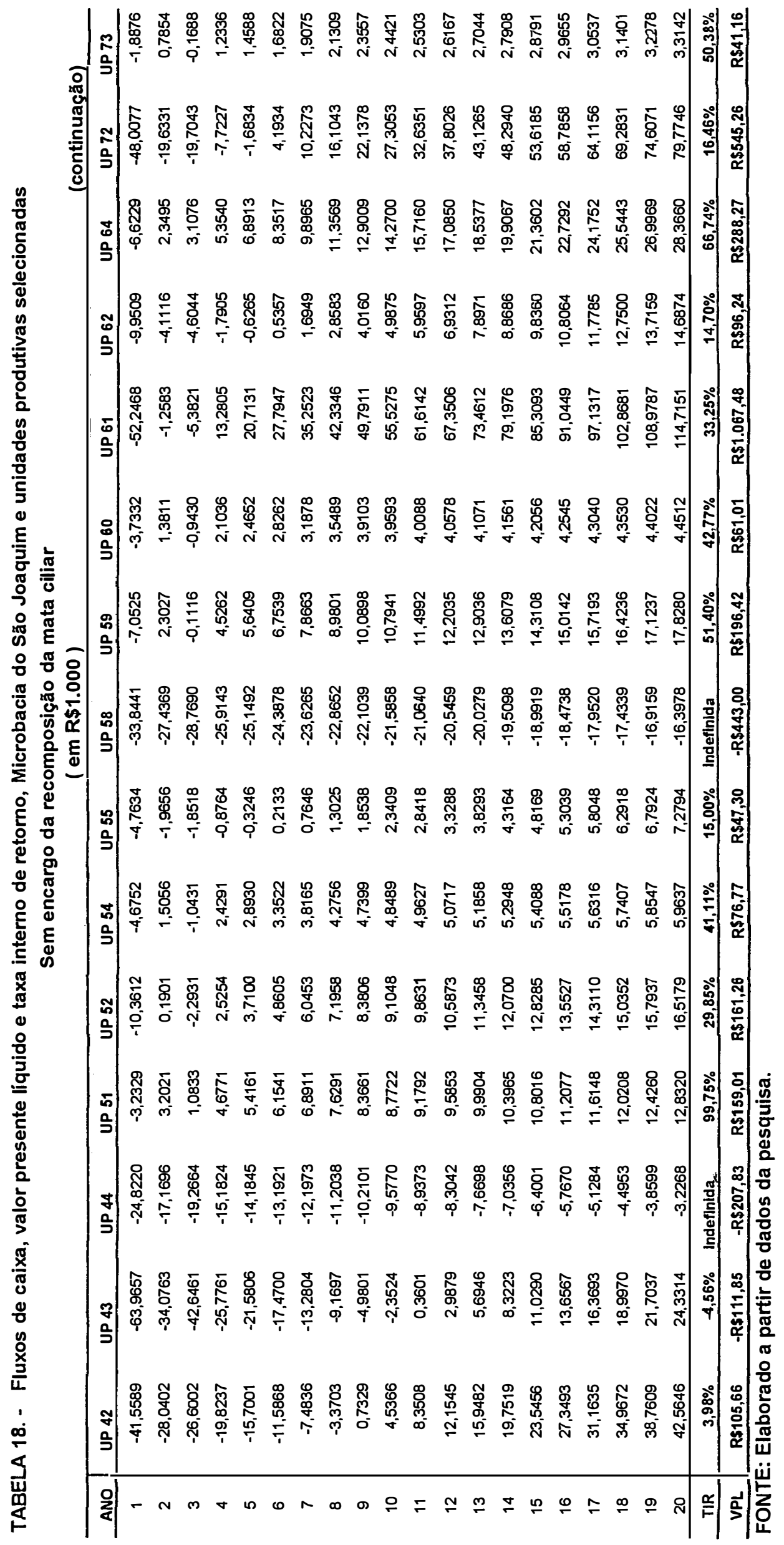




\subsection{Demanda por água tratada e excedente do consumidor}

Como proposto no capítulo referente, à metodologia, procedeu-se à estimação da demanda por água tratada dos consumidores urbanos de Pirassununga com o objetivo de estimar o ganho de bem-estar provocado por um possível aumento da oferta de água. O deslocamento da curva de oferta poderá vir a ocorrer em conseqüência de uma vazão média melhor distribuída ao longo do ano, obtida pela melhoria da capacidade de infiltração de água no solo, e maior recarga do sistema aqüífero. Simultaneamente, poderá se deslocar, também, pela diminuição no custo de tratamento da água, uma vez que a redução na perda de solo por erosão hídrica acarretará menor concentração de sedimentos. Este estudo se propõe a considerar a primeira possibilidade de deslocamento da curva de oferta.

O modelo de demanda agregada proposto definiu o Consumo por ligação de água encanada $\left(C_{a}\right)$ como variável dependente e o Preço marginal $\left(P M_{a}\right)$, a Diferença $\left(D_{p}\right)$, o Número de residentes por ligação $(N)$ e a Renda por ligação $(R)$ como variáveis independentes. Entretanto, não foi possível obter todos os dados representativos dessas variáveis, discutidas a seguir:

Consumo de água por ligação - não foi possível separar o consumo de água por categoria de usuário. Assim, o consumo mensal utilizado se refere ao das residências e dos edifícios de apartamentos, bem como dos prédios públicos, comerciais e industriais. Esta variável (em $\mathrm{m}^{3} /$ ligação) foi obtida pelo quociente entre os dados mensais de água distribuída e o número de ligações no mês correspondente, ambos fornecidos pela SAEP.

Residentes por ligação-dados sobre população urbana de Pirassununga foram encontrados somente para os anos de 1.980, 1.988, 1.989, 1.990 e 1.991. A partir desses dados estimou-se para os anos seguintes uma taxa média de crescimento, permitindo a obtenção da variável, medida em número de habitantes por ligação. 
Renda por ligação $\left(R_{e}\right)$ - dados de renda da população para o período também não foram encontrados. Decidiu-se pela utilização da proxy, Valor Adicionado Anual do Município, publicado pelo SEADE. Também para essa variável foi preciso estimar os valores para alguns anos, expressos em R\$ por ligação.

Neste estudo, propõe-se uma análise baseada na premissa de que a alteração do deflúvio permite uma ampliação da oferta de água pelo serviço municipal de tratamento e distribuição, provocando um deslocamento da curva de oferta para a direita. Se a curva de demanda por água for negativamente inclinada, o deslocamento da oferta provocará uma redução de preço e aumentará a quantidade consumida, configurando-se um ganho de bem-estar ${ }^{15}$. O ganho de bem estar depende da elasticidade-preço da demanda e pode ser medido através do conceito de excedente do consumidor.

\subsubsection{A estimativa da função de demanda por água tratada}

Foi usada a forma funcional linear para estimar a demanda urbana por água tratada, em Pirassununga. Como variáveis independentes foram coletados valores para: o número de residentes por ligação $\left(\mathbf{X}_{1}\right)$, preço marginal por $\mathrm{m}^{3}$ consumido $\left(X_{2}\right)^{16}$, valor da diferença entre o montante pago e aquele que deveria ser pago caso o volume medido por ligação fosse cobrado ao preço da última unidade consumida $\left(\mathbf{X}_{3}\right)$ e o valor adicionado municipal por ligação $\left(\mathbf{X}_{4}\right)$, como uma "proxy" para a renda por ligação.

O método de estimação utilizado foi o dos quadrados mínimos ordinários (MQMO). Destaca-se, porém, que o uso do mesmo, quando os preços cobrados pelo bem são em blocos como ocorre com a água, resulta em estimativas tendenciosas e inconsistentes dos parâmetros ( ver, por exemplo, Grifin e Martin, 1981 e Herwitt e Haneman, 1995). Por outro lado, resultados de vários estudos revelam que os coeficientes obtidos pelo MQMO estão bastante próximos daqueles estimados por

\footnotetext{
${ }^{15}$ Este argumento foi apresentado por PINSTRUP-ANDERSEN (1979) e citado por SILVA (1995), que a utilizou para estimar ganhos sociais advindos da adoção de inovações tecnológicas.
} 
outros métodos, como o das variáveis instrumentais (Henson, 1984;e Deller et al., 1986) e de análise de probito (Terza, 1986). Além disso, a deficiência dos dados disponíveis para o presente estudo não atenderia às exigências de alguns daqueles modelos que estimam parâmetros consistentes. Em se tratando de uma série temporal (dados mensais referentes ao período entre janeiro de 1988 e outubro de 1996) verificou-se a necessidade de um ajuste por meio de um modelo autoregressivo. 0 ajuste forneceu os seguintes resultados (Tabela 19):

Tabela 19. Valores obtidos nos ajustes de funçōes aos dados de consumo de água tratada, Pirassununga, 1988-96.

\begin{tabular}{crrrr}
\hline variável & parâmetro & erro padrão & valor de " $\mathrm{t}$ " & probabilidade \\
\hline $\begin{array}{c}\text { Modelo linear } \\
\text { intercepto }\end{array}$ & $-100,3119$ & 22,7149 & $-4,416$ & 0,0001 \\
$\mathrm{X}_{1}$ & 32,4564 & 6,9391 & 4,663 & 0,0001 \\
$\mathrm{X}_{2}$ & $-9,4439$ & 5,7918 & $-1,631$ & 0,1062 \\
$\mathrm{X}_{3}$ & $-0,8108$ & 0,5421 & $-1,496$ & 0,1379 \\
$\mathrm{X}_{4}$ & 0,0007 & 0,0002 & 2,920 & 0,0043 \\
$\mathrm{R}^{2}=0,7799$ & & & & \\
Durbin-Watson $=1.9573$ & & & \\
\hline
\end{tabular}

Fonte: Elaborado a partir de dados da pesquisa.

Os resultados fornecem a seguinte função:

a) modelos lineares:

$$
\begin{aligned}
& Q=a_{0}+a_{1} P+a_{2} D+a_{3} R+a_{4} P o+u \\
& Q=-100,31-9,44 P-0,81 D+0,0007 R+32,45 P o
\end{aligned}
$$

Ao adotar-se a forma linear, é necessário ressaltar que a elasticidade varia ao longo da função demanda e, portanto, a elasticidade foi estimada para o ponto

\footnotetext{
${ }^{16} \mathrm{O}$ preço marginal corresponde ao preço da última unidade de água consumida no mês.
} 
médio da função encontrada, aliás, procedimento semelhante ao de Andrade et al. (1996), cujo trabalho apresenta ampla e criteriosa revisão sobre o assunto.

Há que se ressaltar que uma variação no preço marginal da água provoca uma variação na quantidade consumida, e também na diferença, que por sua vez também influenciará o consumo. Assim, pode-se obter a estimativa para a elasticidade-preço da demanda $\eta_{Q}$ pela soma da elasticidade-preço marginal e elasticidade-diferença. Todavia, observam Nieswiadomy \& Molina (1989), "para uma mudança proporcionalmente uniforme em toda a estrutura tanifánia, a resposta do consumidor pode ser obtida somando-se as 2 elasticidades. Mudando só o preço intramarginal a elasticidade preço mostra o efeito de uma mudança em todos os PMas e intramarginais, com a diferença constante". Portanto, para a estimativa do valor do excedente do consumidor adotou-se apenas o parâmetro da elasticidade-preço da demanda por água tratada em Pirassununga.

A estimativa do valor da elasticidade-preço da demanda, com base no parâmetro obtido na função de demanda agregada por água tratada, deu-se segundo procedimento sugerido por Oliveira \& Pino (1985). Foi encontrado o valor $-0,1547$, a ser utilizado para se obter a estimativa do valor do beneficio social, através da variação do excedente do consumidor.

Também usando o modelo linear, e com as mesmas variáveis, Billings \& Agthe (1980) obtiveram, para a elasticidade-preço, os valores de -0,46 com o modelo linear e -0,267 com o modelo logaritmico em dados de Tucson, Arizona, para dados entre janeiro de 1974 e dezembro de 1977. Foster \& Beattie (1979) encontraram os valores de $-0,67$ para dados de Great Bend, de $-0,76$, em Colorado Springs e de $-0,44$ para Huntsville.

Estes resultados também podem ser comparados aos encontrados por Andrade et al.(1996) em estimativa de demanda por água com dados de pesquisa realizada pela Empresa de Saneamento do Paraná, em 27 municipios daquele estado. Realizaram várias estimativas, segundo diferentes classes de renda familiar, obtendo os resultados para a elasticidade-preço: até 2 salários minimos, -0.6247 ; de 2 a 10 salários minimos, -0.1652 ; acima de 10 salários minimos, -0.2163 ; geral, -0.2404 . 


\subsubsection{A variação do excedente do consumidor}

A variação do excedente do consumidor, como forma de se determinar o benefício social em uma avaliação de projeto, foi estimada de acordo com a proposta metodológica de Contador, já explicitada na seção 2.6.1 deste trabalho. As variáveis básicas para se efetuar o cálculo constituem-se no valor de mercado do produto $\mathbf{V}_{\mathbf{0}}$, no valor da elasticidade-preço da demanda $\boldsymbol{\eta}$, e na variação da quantidade ofertada elou consumida, que permitem estimar a variação no excedente do consumidor $\Delta \mathbf{W}_{\mathrm{b}}$.

Todavia, propõe-se uma análise invertendo a incógnita: qual seria a variação necessária na oferta de água, ( $\Delta \mathbf{Q}$ / $\mathbf{Q}$ ),para que o valor do benefício social, medido pela variação do excedente da consumidor, venha a ser igual ao montante que poderá ser despendido para promover a adequação ambiental proposta?

Assim, tem-se:

$$
\Delta W_{b}=(1 / \eta) V_{0}(\Delta Q / Q) \cdot[1+(1 / 2) \cdot(\Delta Q / Q)]
$$

onde $\Delta \boldsymbol{W}_{\mathrm{b}}$ é a estimativa da variação do excedente do consumidor que procura-se que seja igual ao total despendido como investimento (obras de terraceamento, divisões de pastos e recomposição de matas) para a adequação ambiental, ou seja, cerca de R\$352 mil. Nesta caso, o investimento está sendo compreendido como uma proxy do impacto ambiental, representada pelo custo da reposição ambiental (mitigation cost).

$\mathbf{V}_{0}$ é o valor de mercado da água tratada, e tomando-se como base na média das quantidades de água tratada consumidas pelos municipes de Pirassununga no ano de 1995 e 1996, tem-se o valor anual correspondente à 7,15 milhões de $\mathrm{m}^{3}$. Este volume ao preço de $\mathrm{R} \$ 0,1875$ por $\mathrm{m}^{3}$ (valor encontrado para o consumo médio de $24 \mathrm{~m}^{3}$ /ligação) leva a um valor de mercado para o produto de cerca de $\mathrm{R} \$ 1,34$ milhões. Utilizando-se o valor da elasțicidade-preço obtida, na equação proposta por Contador, chega-se, por aproximação, ao valor de $4,1 \%$. 
Não se dispõe, no momento, de elementos que permitam estimar com certo grau de acuidade, se o projeto de adequação ambiental trará como resultado um aumento de $4,1 \%$ na vazão média do Córrego São Joaquim - pode-se afirmar, com segurança, que haverá aumento no deflúvio, mas não o quanto irá crescer. Mesmo para a microbacia em estudo, que possui expressivo acervo de informações por ter sido prioridade para os institutos de pesquisa agropecuária do Estado de São Paulo, é possivel obter-se uma estimativa desta variação. Todavia, um acréscimo de $4,1 \%$ é extremamente irrisório, e pode-se dizer que poderá ser superado, com facilidade, com a adoção das medidas preconizadas.

Técnicos da Companhia de Desenvolvimento do Estado de São Paulo (CODASP), assim como outros entrevistados sobre o assunto, confirmam a possibilidade de que tal evento possa vir a ocorrer, e como exemplo, citam o trabalho de recuperação realizado pela empresa na microbacia que fornece água para o Município de Penápolis, onde dobrou o volume de água produzido pelo manancial. Naquele município, é de se esperar que a comunidade urbana esteja motivada a participar e compartilhar de programas ambientais, pois a adequação ambiental das atividades agropecuárias, naquela microbacia, permitiu equacionar o sério e crescente problema de racionamento de água, até então enfrentado pelos munícipes.

Quanto a este aspecto, em Pirassununga, não deve ser esperado que ocorra entre os moradores o mesmo efeito persuasivo, uma vez que, a atual vazão do manancial é plenamente suficiente para suprir as necessidades locais. Desta maneira, caso o abastecimento de água seja o único elemento determinante para a tomada de decisão com relação à adequação ambiental da microbacia do São Joaquim, à luz da economia de mercado, não será executado, pois como o manancial produz acima das necessidades, o volume adicional de água gerado pelo aumento da vazão média, possui custo de oportunidade zero.

Assim sendo, fica caracterizado o caráter exploratório desta parte do estudo, onde o objetivo principal foi exercitar o método e verificar suas condições de aplicabilidade. Ainda que sejam encarados com a devida reserva, os estimadores obtidos no ajuste das funções para a demanda por água encanada, principalmente pela precariedade de parte dos dados básicos em forma de proxy, pela não existência 
de informações mais precisas, o método apresentou-se útil. Todavia, há que se ressaltar a necessidade de pesquisas para ampliar o acervo sobre o comportamento hidrológico das bacias e assim possibilitar melhores avaliações em outras áreas. 


\section{CONCLUSÃO E CONSIDERAÇÕES}

A proposta básica deste estudo foi avaliar parte do impacto ambiental do uso inadequado do solo para fins agropecuários e verificar a viabilidade econômica da adoção das medidas mitigadoras recomendadas, tendo como área de estudo a microbacia do córrego São Joaquim no Município de Pirassununga, Estado de São Paulo. Além dos retornos ao produtor, buscou-se também, aferir parte dos benefícios que o controle da erosão, na área rural, traz para a zona urbana. Como esse córrego serve ao sistema municipal de águas e esgoto, procurou-se, através de uma estimativa da demanda por água tratada, medir o acréscimo do excedente do consumidor como conseqüência de um programa de conservação do solo.

Verificou-se em $523,80 \mathrm{ha}$, a retirada da vegetação original e ocupação para uso de produção agropecuária além das possibilidades das respectivas classes de capacidade de uso. Mesmo nas demais áreas, utilizadas de acordo com a capacidade de uso, há prejuízo ambiental pela excessiva erosão do solo, surgimento de sulcos e voçorocas, turbidez na água, assoreamento do leito do córrego e menor recarga dos aqüiferos. A ausência de práticas de manejo, em muitas glebas, acarreta uma severa perda de solo, de 49,81ha t/ha/ano. As medidas sugeridas, podem permitir uma redução expressiva na perda de solo, caindo para 9,71t/ha/ano.

Para a microbacia como um todo, a análise econômica da aplicação das medidas mitigadoras indicou a viabilidade da adoção das mesmas, apresentando uma taxa interna de retorno (TIR) de $10,86 \%$, e um valor presente líquido de $R \$ 930$ mil (atualizado $6 \%$ ao ano), em um horizonte de 20 anos. Porém, a atratividade econômica do projeto fica ofuscadal pelo reduzido retorno imediato da adequação no 
curto prazo (cerca de $\mathrm{R} \$ 23,6 \mathrm{mil}$ ), diante do volume total de recursos requeridos para a implantação do projeto ( $\mathrm{R} \$ 352 \mathrm{mil})$, pois resume-se à diminuição nos custos com o tratamento da água e com a dragagem do córrego. Deve-se destacar também, o fato de que os benefícios maiores advirão com os ganhos em produtividade física dos solos, pela recuperação e preservação dos mesmos, a médio e longo prazos, gradativamente; isso implica em um fluxo de caixa negativo por 7 anos, e que, descontados a $6 \%$ ao ano, resultam em um payback de 16 anos - bastante longo.

Do ponto de vista social as expectativas são de inúmeras externalidades positivas: melhoria da qualidade da água, condições para o repovoamento da fauna e do aqüífero, recuperação e preservação das matas e portanto, da biodiversidade, melhores condições de vida para a população da microbacia e melhoria na renda para a maioria das unidades produtivas. Assim sendo, do ponto de vista dos benefícios gerados para a sociedade, o projeto de adequação através das medidas mitigadoras é atraente.

Por outro lado, sob a ótica individual do empresário rural, a situação apresenta-se heterogênea, com a TIR variando desde valores negativos $(-4,97 \%)$ até valores bastante altos $(62,05 \%)$. Isso significa, que a mudança proposta não é considerada economicamente eficiente, uma vez que verificou-se melhoria nas condições de alguém, piorando, no entanto, a de outros. Evidentemente, os valores derivam dos fluxos de caixa, conferindo maior ou menor grau de dificuldades a exequibilidade do projeto. Há casos onde o fluxo de caixa permanece negativo durante os 20 anos, não permitindo, inclusive, estimar a TIR. Essa variação está condicionada pela proporção da área ocupada de forma inadequada na unidade produtiva e, também, pela lucratividade das culturas ali existentes. Como a recuperação da receita perdida (por plantio de matas elou pastagens), neste estudo, só poderá ser reposta com o ganho de produtividade obtido com o manejo adequado das demais áreas, a proporcionalidade entre elas é que irá determinar o grau de aceitabilidade privada de cada projeto. Tal fato confirma-se observando-se na microbacia a localização das unidades cujos projetos apresentam fluxo de caixa sempre negativo, para o qual a TIR é indefinida ou menor que $0 \%$ (UP 39,UP 43, UP 44, UP 58) (FIGURA 14 ). Estas, em sua maioria, ficam nas cabeceiras dos córregos e portanto nas áreas mais íngremes, onde as medidas mitigadoras são imprescindíveis para o manejo da microbacia, pois, 
podem por em risco o trabalho de conservação daquelas unidades mais abaixo. Propriedades nestas condições requerem um tratamento diferenciado, e concessão de privilégios compensatórios.

É certo que o método da análise custo-benefício apresenta a limitação de estar baseado nos preços dos mercados de insumos e produtos, e que tanto os preços relativos e como as lucratividades poderão se alterar. Todavia, nestes casos tratam-se de mudanças de atividades com fins comerciais para atividades de preservação ambiental, onde não se dará produção comercializável, portanto, certamente com redução de receita.

O pressuposto deste estudo em restringir a substituição das atividades inadequadas por pastagem, tradicionalmente já empreendida na microbacia, ou por área de preservação, acatando a legislação, teve por objetivo observar o desempenho econômico dos projetos individuais no limite inferior das possibilidades atuais de mercado. A introdução de alternativas de produção com perspectivas de maiores lucros tem sido preconizada como medida complementar em projetos de recuperação ambiental ligados à atividade agrícola. Todavia esses estudos não têm feito referências ao aumento nos custos de transações acarretados por essa medida, já que haveria necessidade desde treinamento do empresário rural e capacitação da mão-de-obra na nova atividade, montagem de infra-estruturas de apoio tanto para a oferta de recursos produtivos como para a comercialização do novos produtos, e até, talvez, desenvolver mercado para a produção. Além disso, os ganhos com essas explorações mais lucrativas poderiam mascarar os resultados referentes às medidas mitigadoras .

Dado as diferenças observadas nas TIRs pode-se concluir pela necessidade de especial atenção à heterogeneidade das condições edáficas de cada unidade produtiva ao se propor um projeto de adequação de uma microbacia. Mesmo que algumas medidas possam ser tomadas para atenuar tal efeito, como subsídio parcial ou total aos investimentos, haverá muita disparidade entre os resultados econômicos de cada empreendimento, com diferentes graus no estímulo ao engajamento. Com referência à essa questão, ressalte-se que, como no caso da microbacia do córrego São Joaquim, as propriedades com maior necessidade de recompor áreas de preservação permanente encontram-se na parte superior das 
vertentes, podendo vir a reduzir a eficácia das medidas mitigadoras adotadas pelas unidades situadas encosta abaixo. Desta forma, crê-se que a maneira racional de abordar a questão seja e elaboração de projetos particularizados para cada microbacia e, dentro das mesmas, para cada uma das unidades produtivas que as compõem.

Para atingir o objetivo acima proposto, pode ser recomendada a adoção, em consonância com a lei de conservação do solo, da implantação de uma espécie de EIA/RIMA ou Plano de Recuperação de Ambiente Degradado (PRAD) - um relatório de impacto ambiental adequado às necessidades dos empreendimentos agropecuários. Tal documento permitirá melhor explicitar e debater as relações econômicas envolvidas, tais como: os processos de atenuação de direitos com a obrigatoriedade das áreas de preservação permanente, a fonte difusa (não pontual) de poluição da água, as externalidades que beneficiam a sociedade como um todo e mais diretamente os munícipes de Pirassununga.

$O$ agricultor, ao praticar-uma-agricultura-que respeite a sustentabilidade do sistema ambiental explorado, estará também contribuindo para a manutenção de uma produção de água mais regular e segura, e de melhor qualidade. conseqüentemente, a sociedade urbana precisa melhor avaliar e reconhecer essa contribuição da agricultura, compartilhando dos custos impostos pela observância das restrições ao uso do solo que conduzam à uma agricultura moderna e sustentável. A esse propósito, através da estimativa do excedente do consumidor, verifica-se que um aumento de cerca de 4,1\% na vazão média do córrego São Joaquim, resultante do uso de medidas mitigadoras, já seria suficiente para tornar a estimativa do valor do benefício social igual ao montante despendido pelos agricultores com a adoção das medidas mitigadoras. Trata-se de quantia irrisória, uma vez adotadas.

Os resultados apresentados na análise econômica mostram que, apesar de ser um investimento atraente, para mais de $50 \%$ dos agricultores o fluxo de caixa dos primeiros 7 a 8 anos dificulta sua adoção. Assim sendo, possiveis programas de recuperação e preservação ambiental nessas áreas deverão levar em conta essa questão.

Com o advento da regulamentação da Política de Recursos Hídricos do Estado de São Paulo, praticada pelos Comitês de Bacias Hidrográficas, passou-se a discutir o gerenciamento, em nivel global, dos vários aspectos da questão da água, e 
sobretudo da cobrança pelo seu uso. Acredita-se que com a atual discussão da cobrança generalizada pelo uso do recurso hídrico, independente da sua origem ou uso, o agricultor passe a ser visto não apenas como agente poluidor - por não controlar a emissão de resíduos químicos e de sedimentos - mas também como um preservador e disponibilizador de água, e que essa função possa vir a ser reconhecida e compensada pela sociedade. Crê-se que o caminho mais indicado seria de garantir privilégios aos adotantes de preservação ambiental e conservação do solo, através de crédito (juro subsidiado) ou taxação (descontos no Imposto Territorial Rural e outros).

Portanto, como principais conclusões desta pesquisa revela-se que:

- os agricultores, dependendo das características de sua propriedade, recebem estímulos econômicos muito variados em intensidade para a adoção de medidas conservacionistas, mantidas as atuais alternativas de produção da região;

- em conseqüência, há necessidade de tratamentos diferenciados por unidade produtiva para se obter dos produtores o esperado engajamento em programas de adequação ambiental no uso agrícola do solo, principalmente ao se considerar a inviabilidade econômica das medidas mitigadoras nas unidades produtivas onde se localizam as nascentes, e portanto, de vital importância para a garantia da qualidade da água;

- resultados exploratórios indicam a possibilidade de que o valor dos benefícios sociais líquidos possam vir a se equiparar ao montante necessário para a adequação e assim, desde que a negociação seja induzida, cria-se a perspectiva da comunidade local, por sua opção, parțicipar do programa.

Finalizando, convém reconhecer as limitações impostas pelo caráter multidisciplinar deste estudo, melhor expressas pela dificuldade em se obter um adequado nível de equilíbrio para as abordagens teórico e prática das diferentes áreas disciplinares. 


\section{REFERÊNCIAS BIBLIOGRÁFICAS}

ANDRADE, T. A. et al. Estudo da função demanda por serviços de saneamento e estudo da tarifação do consumo residencial. Rio de Janeiro: IPEA, 1995. 61p. (Texto para discussão, 415).

BEALANDS, G.E. Scoping methods and baseline studies. In: Environmental impact assessment: theory and practice. London: Routledge, 1988. 332p.

--; DUINKER, Peter N. An ecological framework for environmental impact assessment. Journal of Environmental Management, v. 18 , p.267-277, 1984.

BELLINAZZI JUNIOR R., BERTOLINI, D. ; LOMBARDI NETO, F. Ocorrência de erosão rural no Estado de São Paulo. In: SIMPÓSIO SOBRE CONTROLE DE EROSÃO, $2^{\circ}$, São Paulo, 1981, Anais, São Paulo: ABGE, p 117-137, 1981.

BERNDT E.R. The demand for electricity: structural and time series approaches. In:The practice of econometrics: classic and contemporary, New York, Addison-Wesley Publishing Company, 1991. 495p.

BERTONI, J. ; LOMBARDI NETO, F. Conservação do solo. São Paulo: Ícone, 1990. 355p.

--.--; --..-; BENATTI JUNIOR, R. Equação de perdas de solo. Campinas: IAC, 1975. 25p. (Boletim Técnico, 21). 
BILLINGS, B.R.; AGTHE, D.E. Price elasticities for water: a case of increasing block rates. Land Economics, v.56, p.73-84, Feb. 1980.

CARNEIRO, C. D. R. et al. Mapa geomorfológico do Estado de São Paulo. São Paulo: IPT, 1981. V.2. (IPT Publicação 1183 - Série Monografias, 5).

CHICOINE, D.; RAMAMURTHY G. Ëvidence on the Specification of Price in the Study of Domestic Water Demand". Land Economics, v.62 , p.26-32, Feb.1986.

CLARK, E. H.; HAVERKAMP, J. A.; CHAPMAN, W. Eroding soils, the off-farm impacts. Washington: Conservation Foundation, 1985.

COASE, R. H. The problem of social cost. Journal of Law and Economics, v.3, p.1-44, 1960.

COMUNE, A.E. A abordagem neoclássica: técnicas de mensuração. In: Ciclo de palestras "economia ambiental: perspectivas de pesquisa". São Paulo: Instituto de Economia Agrícola, 1995.

CONTADOR, C.R. Avaliação sociạl de projetos. 2 ed. São Paulo: Atlas, 1988. $316 p$.

DAHLMAN, C. J. The property of externality. Journal of Law and Economics, v.22, p.141-162, 1979.

DELLER, S. C.; CHICOINE, D.; RAMAMURTHY, G. Instrumental variables .approach to rural water service demand". Southern Economic Journal, v.53, p. 333-46, out. 1986.

DESAIGUES, B. L'Economie du patrimoine naturel: quelques développements récents. Revue D'Economie Politique, v.100, n.6, p.707-785, 1990. 
DIXON, J. A.; SHERMAN, P.B. Economics of protected areas: a new look at benefits and costs. Washington: Island Press, 1990. 234p.

DONZELLI, P. L. et al. Técnicas de sensoriamento remoto aplicadas ao diagnóstico básico para planejamento e monitoramento de microbacias hidrográficas. In: LOMBARDI NETO, F.; CAMARGO, O. A. (Coords.). Microbacia do córrego São Joaquim (Município de Pirassununga, SP.). Campinas: IAC, 1992. p.91119. (Documentos IAC, 29)

FORSTER, D. L.; ABRAHAM, G. Sediment deposits in drainage ditches: a cropland externality. Journal of Soil and Water Conservation, v.40, p.141-143, 1985.

FOSTER, H. S.; BEATTIE, B.R. Urban residential demand for water in the United States. Land Economics, v.55, p.43-58, Feb. 1979.

GIBBONS, D. C. The economic value of water. Washington: Resouces for the future Inc., 1986. $101 p$.

GITTINGER, J.P. Economics analysis of agricultural projects. Baltimore: John Hopkins University Press. 1972.

GORDON, H.S. The economic theory of a common property resource: the fishery. Journal of Political Economics, v.62, p.124-132, 1954.

GRAAFF, J. Soil conservation and sustainable land use: an economic approach. Amsterdam: Royal Tropical Institute, 1993. 191p.

GRIFFIN, A.H., MARTIN, W.E., WADE J.C. Urban residential demand fo water in the United States: comment. Land Economics, v.57, p.252-256, May 1981.

HEADY, E. O. Some fundamentals of conservation economics and policy. Journal of Farm Economics, v.32, n.4, part. 2, p.1182-1195, Nov. 1950. 
HECKER FILHO, J.; OLIVEIRA, J. B. Levantamento pedológico detalhado. In: LOMBARDI NETO, F.; CAMARGO, O. A. (Coords.). Microbacia do córrego São Joaquim (Município de Pirassununga, SP.). Campinas: IAC, 1992. p.2740. (Documentos IAC, 29).

HELMERS, F.L.C.H. Project planning and income distribuition. Boston, Martinus Nijhoff, 1979.

HENSON, S. "Electricity demand estimates under increasing block rates". Southern Economic Journal, v.51, p. 147-56, jul. 1984.

HEWITT, J.A.; HANEMANN, W.M. A Discrete/continuous choice to residencial water demand under block rate pricing. Land Economics, 71,n. 2, maio 1995.

HICKS, J. R. Revision de la teoria de la demanda. México: Fondo de Cultura Econômica, 1958. 220p.

HOWE, C.W.; LINAWEAVER Jr., F.P. The impact of price on residential water demand and its relation to system design and price structure. Water Resources Research, v.3, n.1,p.13-32, 1967.

INSTITUTO DE PESQUISAS TECNOLÓGICAS. Orientações para combate à erosão no Estado de São Paulo (Bacia do Peixe-Paranapanema). São Paulo, 1986. v.3.

JANVRY, A.; SADOULET, E.; SANTOS, B. Project appraisal for sustainable rural development: notes for IFAD's Operacional Guidelines. [S.I.]: IFAD, May 1993. 54p.

LARSON, E. W.; PIERCE, F. J. \& DOWDY, R. H. The threat of soil erosion to longterm crop production. Science, v.219, p.458-465, 1983.

LEONTIEF, W. Environmental repercussions and the economic struture: an inputoutput approach. The Review of Economics and Statistics, v.52, p.262-271, 1970. 
LOMBARDI NETO, F.; BERTONI, J. Tolerância de perdas de terra para solos do Estado de São Paulo. Campinas IAC, 1975. 12p. (Boletim Técnico, 28).

-_; ROCHA, F.; BACELLAR, A. A. Planejamento agroambiental da microbacia hidrográfica da Ribeirão Cachoeirinha, Município de Iracemápolis, SP, utilizando um sistema de informação geográfica. Campinas: Instituto Agronômico, 1997. 4p.

LUECK, D. Property rights and the economic logic weldlife institutions. National Resources Journal, v.35, n.3, p.625-670, Summer, 1995.

MAGRATH, W.; ARENS, P. The Costs of soil erosion on jave: a natural resource accounting approach. Washington: World Bank, 1989.

MENCK, P. C. M., "Avaliação do Controle da Erosão na Microbacia do Ribeirão Iperó, em Araçoiaba da Serra, Estaḍo de São Paulo", Piracicaba, $1993.181 \mathrm{p}$. Dissertação (Mestrado) Escola Superior de Agricultura "Luis de Queiróz", Universidade de São Paulo.

MOREIRA, I. V. D. Avaliação de impacto ambiental: instrumento de gestão. Cadernos Fundap, São Paulo, v.9, n.16, p.54-63, jun. 1989.

NOGUEIRA, J. M. The economics of soil erosion control measures and factors affecting their adoption, with special reference to south-east Brazil. Londres, 1982. 518p. Tese (Doutorado) - University Wye College.

NORDIN, J.A. A proposed modification of Taylor's demand analysis: comment. The Bell Journal of Economics, v.7, p.719-721, Autumn 1976.

OLIVEIRA, A. X. \& PINO, F. A. Elasticidade em modelos de séries temporais. In: ENCONTRO BRASILEIRO DE ECONOMETRIA, 7., Vitória, ES, 1985. Anais Rio de Janeiro, Sociedade Brasileira de Econometria, 1985, p. 401-412. 
OTANI, M., CARRIERI, A. P.; ANGELO, J. A. Microbacia-piloto do Córrego São Joaquim, DIRA de Campinas, Estado de São Paulo: estudo comparativo 1988-94. Informações Econômicas, v.26, n.1, p.47-60, jan. 1996.

PEARCE, D. Economics, equity and sustainable development. Futures, v.20, n.6, p.598-605, 1988.

------; BARBIER, E.; MARKANDYA, A. Sustainable development: economics and environment in the third world. London: Earthscan Publications Ltd, 1990. 217p.

PEDRO JUNIOR, M. et al. Características climáticas. In: LOMBARDI NETO, Francisco; CAMARGO, Otávio A. (Coords.). Microbacia do córrego São Joaquim (Município de Pirassununga, SP.). Campinas: IAC, 1992. p.113. (Documentos IAC, 29).

PIERCE, F.J. et al. Productivity of soils in the Corn Belt: An Assessment of the LongTerm Impact of Erosion. Journal of Soil and Water Conservation., v. 39, 1984.

PIGOU, A.C. The economics of welfare. London: Macmillan \& Co., 1928.

PINSTRUP-ANDERSEN, P. Modem agicultural technology and income distribution: the market price effect. European Review of Agricultural Economics, v.6, n.1, p.17-46, 1979.

RANDALL, A. Resource economics: an economic approach to natural resource and environmental policy. New York: John Wiley \& Son, 1987. 434p.

RIBAUDO, M. O. Reducing soil erosion: offsite benefits. Washington: USDA, 1986. (Report, 561).

SANCHEZ, L. E. Avaliação de impacto ambiental na mineração: interações entre o projeto técnico e os estudos ambientais. In: SIMPÓSIO EPUSP sobre Controle Ambiehtăl e Segurança na Mineração. São Paulo, 1989, Anais: EPUSP. 
SÃO PAULO. Secretaria de Agricultura e Abastecimento. Coordenadoria da Pesquisa de Recursos Naturais. Política setorial de recursos naturais para o Estado de São Paulo. São Paulo, 1986. 134p.

SÃO PAULO. Secretaria de Agricultura e Abastecimento. Programa estadual de microbacias hidrográficas - proposta BIRD. Anexo IV: estratégia técnica do programa. São Paulo: SAA, 1989. 84p.

SILVA, C. R. L. da. Inovação Tecnológica e distribuição da renda: impacto distributivo dos ganhos de produtividade da agricultura brasileira. São Paulo: IEA, 1995. 245p. (Coleção Estudos Agrícolas, 2).

SMITH, V. K. Nonmarket valuation of environmental resources: an interpretative appraisal. Lands Economics, v.69, n.1, p.1-26, Feb. 1993.

SOUTHGATE, D.; FORSTER, D. L. Economics of controlling nonpoint source pollution and soil erosion. In: CONGRESSO BRASILEIRO E ENCONTRO NACIONAL DE PESQUISA SOBRE CONSERVAÇÃO DO SOLO, 8., Londrina, 1990. Anais. Londrina: IAPAR, 1996. 312p.

SOUTHGATE, D.; MACKE, R. the downstream beneficts of soil conservation in third world hydroeletric watersheds. Lans Economics, v.65, n.1, p.38-48, Feb. 1989.

STEIN, D.P., ROTTA, C.; STEFANI, F. L. Geologia e geomorflogia. . In: LOMBARDI NETO, F.; CAMARGO, O. A. (Coords.). Microbacia do córrego São Joaquim (Município de Pirassununga, SP.). Campinas: IAC, 1992. p.1526. (Documentos IAC, 29).

TAYLOR, L.D. The demand for electricity: a survey. The Bell Joumal of Economics, v.6, p.74-110, Spring 1975.

TERZA, J. V. "Determinants of household electricity demand: a two-stage probit approach". Soutern Economic Journal, v. 52, p.1131-1139, Apr. 1986. 
TOLEDO, P. E. N. de; OTANI, M. N. Diagnóstico socioeconômico da microbacia do córrego São Joaquim. In: LOMBARDI NETO, F.; CAMARGO, O. A. (Coords.). Microbacia do córrego São Joaquim (Município de Pirassununga, SP.). Campinas: IAC, 1992. p.133-138. (Do-cumentos IAC, 29)

TROPPMAIR, H.; MACHADO, M.L.A. Variações da estrutura da mata de galeria na bacia do Rio Corumbatai (SP) em relação à água do solo, do tipo de margem e do traçado do rio. Biogeografia_(IG-USP)

United States Department of Agricultural. Soil, sater and related resources in the United States: analysis of resource trends. 1980 Rce Appraisal Part II. Washington: USDA, 1981.

VARIAN, H. R. Microecnomia: princípios básicos. 2. Ed. Rio de Janeiro: Campus, 1994.

VEIGA FILHO, A. A. et al. Análise de investimentos em adoção de tecnologias e conservação do solo no Estado de São Paulo. Agricultura em São Paulo, v.39, n.1, p.133-154, 1992.

WATHERN, P. An introductory guide to environmental impact assessment:: theory and practice. London: Routledge, 1988. 332p.

WISCHMEIER, W. H.; SMITH, D. D. Predicting rainfall-erosion losses: a guide to conservation planning. Washington: USDA, 1978. 58p. (Agriculture Handbook, 537)

WONG, S.T. "A Model of Municipal Water Demand: a case study of Northeastern Illinois". Land Economics , v.48, p. 34-44, feb. 1972.

YOUNG, R.A. "Price elasticity of demand for municipal water: Case Studey of Tucson, Arizona". Water Resources Research, v.9, p. 1068-1072, dec. 1973. 


\section{APÊNDICE 1}




\section{AS DIFERENTES CLASSES DE USO DE SOLO E AS RECOMENDAÇÕES CONSERVACIONISTAS CONSIDERADAS $\left({ }^{16}\right)$}

As recomendações copservacionistas para as diferentes classes de uso, são as seguintes:

\section{CLASSE - declividade menor que $3 \%$}

\section{Cultura anuais ou temporárias}

- proceder ao rompimento ou dessagregação de camada compacta.

- preparo do terreno de acordo com cultura escolhida.

- plantio em nivel ou em contorno.

- rotação de culturas.

- adubação verde e/ou orgânica: manter ou aumentar o teor de matéria orgânica do solo.

- aplicação de corretivo e fertilizantes (manutenção e restituição): função do solo e cultura.

- tratos culturais normais: controle de ervas daninhas, pragas e doenças.

- não queimar restos culturais: incorporar ou deixar na superfície do solo.

\section{Cultura permanente}

- proceder rompimento ou desagregação da camada compacta.

- preparo do terreno de acordo com cultura escolhida.

- calagem.

\footnotetext{
${ }^{16}$ Baseado Lombardi Neto, F. Recomendaçōes Conservacionistas para diferentes classes de uso. Seção de Fotointerpretação, Instituto Agronômico, Campinas, SP (mimeo.)
} 
- adubações: químicas e orgânicas - função do solo e cultura.

- plantio em nível ou em contorno.

- utilização de culturas de cobertura entre as fileiras de plantas.

- trato culturais normais: controle de pragas e doenças.

- controle do mato no período de chuva com roçadeira.

- proteção contra fogo e outros agentes destruidores.

\section{Pastagem}

- rompimento ou desagregação da camada compacta.

- rotação de pastos com culturas.

- utilização e trato das pastagens de acordo com o tipo de exploração pecuária.

- apliçação de corretivo e fertilizantes: (manutenção e restituição) função do solo e capim.

- dotação adequada de animais por unidade de área.

- pastoreio rotacional, para favorecer a revegetação natural e aumentar o vigor da vegetação herbácea.

- controle de pragas e doenças.

- melhoramento das aguadas e uso de local adequado para distribuição de sal, alimentos e aprigos.

- locação de cercas segundo normas conservacionistas.

- proteger pequenas barragens e sangradouros com cerca.

\section{Florestas}

\section{a) Nativas}

- interdição ao gado.

- proteção contra fogo e outros agentes destruidores.

\section{b) Reflorestamento}

- escolha das essências florestais. 
- preparo de mudas.

- aplicação de corretivo e fertilizantes: (manutenção e restituição)

- função do solo e espécie.

- proteção contra o fogo e outros agentes destruidores.

- remoção dos produtos florestais, segundo curva de nível.

\section{Refúgio para Fauna Silvestre}

- aproveitamento das áreas limites das florestas para refúgio da fauna.

- plantio e manutenção de vegetação permanente e apropriada para fornecer ambiente para desenvolvimento de padrões de vida para a fauna nestas áreas.

\section{CLASSE II - declividade entre 3 e $6 \%$}

\section{Culturas anuais ou temporárias}

- proceder rompimento ou desagregação da camada compacta.

- preparo do terreno de acordo com a cultura escolhida.

- não queimar restos culturais: incorporar ou deixar na superfície.

- plantio em nível ou em contorno.

- aplicação de corretivos e fertilizantes: função do solo e cultura.

- culturas em faixas ( rotação, retenção ou conjugadas).

- adubação verde.

- manutenção ou melhoramento das condições físicas do solo (rotação de culturas com raizes profundas ou que deixem grande quantidade de material residual).

- alternância de capinas.

- faixas de vegetação permanente.

- terraços: de base larga, de preferência em nível.

- canais divergentes. 
- manutenção dos terraços e canais.

- controle do excesso de água (áreas irrigadas).

- conservação da umidade.

\section{2) Culturas permanentes}

- proceder ao rompimento ou desagregação da camada compacta.

- calagem.

- adubações: químicas e orgânicas - função do solo e cultura.

- plantio em nível ou em contorno.

- utilização de culturas de cobertura entre as fileiras de plantas.

- trato culturais normais: controle de pragas e doenças.

- controle do mato no período de chuva com roçadeira.

- terraços: de base larga e em nível.

- manutenção dos terraços e canais.

- protẹção contra fogo e outros agentes destruidores.

\section{3) Pastagem}

- rompimento e desagregação da camada compacta.

- plantio de gramíneas associadas com leguminosas.

- rotação de pastos com culturas.

- utilização e trato das pastagens de acordo com o tipo de exploração pecuária.

- aplicação de corretivos e fertilizantes: função do solo e capim.

- dotação adequada de animais, por unidade de área.

- pastoreio rotacional.

- local adequado para distribuição de sal e alimentos.

- proteção com cercas pequenas barragens e sangradouros.

- controle do fogo e outros agentes destruidores.

\section{4) Florestas}


a) Nativas

- interdição ao gado.

- proteção contra o fogo e outros agentes destruidores.

- regeneração.

\section{b) Reflorestamento}

- escolha das essências florestais.

- viveiros em locais apropriados.

- plantio em contorno.

- proteção contra fogo, saúva e outros agentes destruidores.

- remoção dos produtos florestais, segundo curva de nível.

\section{5) Refúgio para Fauna Silvestre}

- aproveitamento das áreas limites das florestas para refúgio da fauna.

- plantio e manutenção de pequenos bolsões de vegetação permanente e específica para fornecer ambiente para o desenvolvimento da fauna.

- estabelecimento, nestas áreas, de práticas que possam proporcionar padrões de vida para a fauna.

\section{CLASSE III - declividade entre 6 e 12\%}

\section{1- Culturas anuais ou temporais}

- as operações de preparo do solo, plantio, cultivo e colheita deverão ser realizadas de tal maneira e com equipamento apropriado a fim de deixar todo o material residual na superfície ou parcialmente incorporado ao solo. Não queimar restos de culturas.

- proceder rompimento ou desagregação de camada compacta.

- plantio em nível ou em contorno. 
- manter o solo coberto durante todo o tempo com cultura ou com restos de cultura.

- manutenção ou aumento da matéria orgânica do solo

- incorporação de resíduos de culturas ou adubação verde orgânica.

- aplicação de corretivos ou fertilizantes: função do solo e cultura.

- rotação das culturas: incluir cultura de inverno e culturas que produzam alta quantidade de material residual.

- culturas em faixas (retenção).

- terraços: de base média em nivel ou gradiente - função do solo e chuvas.

- canais escoadouros (complemento terraços com gradiente).

- canais divergentes.

- manutenção dos terraços e canais.

\section{2) Culturas permanentes}

- proceder rompimento ou desagregação da camada compacta.

- preparo do terreno de acordo com cultura planejada.

- calagem: de acordo com solo e cultura.

- adubações: de acordo com solo, cultura e idade.

- plantio em nível ou em contorno.

- manejo do mato no período de chuva - roçar.

- embaciamento.

- sistema de terraços: base média ou cordões em contorno.

- canais escoadouros.

- manutenção anual dos terraços e canais escoadouros.

- tratos culturais e controle de pragas e doenças.

- proteção contra o fogo e outroß agentes destruidores.

\section{3) Pastagem}

- rompimento ou desagregação da camada compacta. 
- aplicação de corretivos e fertilizantes: função do solo e capim.

- rotação de pastos com culturas (reformas).

- utilização e trato das pastagens de acordo com o tipo de exploração pecuária.

- dotação adequada de animais por unidade de área.

- pastoreio rotacional.

- controle do fogo.

- controle de pragas e doenças.

- local adequado para distribuição de sal, alimentos e abrigos para os animais.

- proteger com cercas pequenas barragens e sangradouros.

- combate às voçorocas.

\section{4) Floresta}

\section{a) Nativas}

- interdição ao gado.

- proteção contra o fogo e outros agentes destruidores.

- regeneração.

- locação e construção de canais divergentes.

b) Reflorestamento

- escolha das essências florestais.

- viveiros em locais apropriados.

- plantio em nível ou em contorno.

- tratos culturais.

- proteção contra o fogo e outros agentes destruidores.

- interdição ao gado.

- locação e construção de estradas, segundo as curvas de nível.

\section{5) Refúgio para Fauna Silvestre}

- idem item Classe II. 


\section{CLASSE IV - declividade entre 12 e $20 \%$}

\section{Culturas anuais e temporais}

- ocasionalmente, em rotações com culturas perenes e pastagens (seguir recomendações culturas da classe III). Culturas permanentes:

- proceder rompimento ou desagregação camada compactada.

- preparo do terreno de acordo com cultura (cova e sulcos).

- plantio e cultivos em nível ou contorno.

- não queimar restos de cultura - incorporar ou manter na superfície do solo com a finalidade de manter ou aumentar o conteúdo de matéria orgânica no solo.

- controle do mato durante período de chuva - roçar.

- calagem.

- sistemas de terraços: base média ou cordões em contorno, em função solo e chuva.

- canais escoadouros.

- manutenção anual dos terraços e canais escoadouros.

- controle de voçorocas.

- proteção contra o fogo e outros agentes destruidores.

\section{3) Pastagem}

- rompimento ou desagregação da camada compacta.

- rotação dos pastos com culturas.

- utilização e trato das pastagens de acordo com o tipo da exploração pecuária.

- descanso dos pastos.

- dotação adequadas de animais por unidade de área.

- pastoreio rotacional.

- controle do fogo. 
- melhoramento das aguadas.

- local adequado para distribuição de sal, alimentos e abrigos para animais.

- proteger com cercas pequenas barragens e sangradouros.

- combate às voçorocas.

- sulcos de retenção.

\title{
4) Florestas
}

- idem a item Classe II

\section{5) Refúgio para Fauna Silvestre}

\author{
- idem a item Classe II
}

\section{CLASSE V}

\section{1) Pastagem}

- aplicação de corretivos e fertilizantes: função do solo e espécie.

- utilização e trato das pastagens de acordo com o terreno e tipo de exploração pecuária.

- pastoreio rotacional.

- controle do fogo.

- melhoramento das aguadas.

- local adequado para distribuição de sal, alimentos e abrigos.

- dotação adequada de animais por unidade de área.

- descanso dos pastos.

\section{2) Florestas}


- idem a item Classe II

\section{3) Refúgio para Fauna Silvestre}

- idem a item Classe II

\section{CLASSE VI}

\section{1) Pastagem}

- aplicação de corretivos e fertilizantes: função do solo e espécie.

- sulcos de retenção.

- controle de voçorocas.

- uso moderado da pastagem.

- utilização e trato das pastagens de acordo com o tipo de exploração pecuária.

- descanso dos pastos.

- pastoreio rotacional.

- controle do fogo, ervas daninhas e pragas.

- melhoramento das aguadas.

- local adequado para distribuição de sal, alimentos e abrigos.

\section{2) Florestas}

- idem a item Classe II

\section{3 ) Refúgio para Fauna Silvestre}

- idem a item Classe II 


\section{CLASSE VII}

1) Pastagem

- uso limite de pastagem

- idem a item classe VI

\section{2) Florestas}

- idem a item Classe II.

\section{3) Refúgio para Fauna Silvestre}

- idem a item Classe II

8. CLASSE VIII - classe de terra não agricultável. Recomendada para:

- refúgio da fauna silvestre

- barragens

- bosques recreativos 
APÊNDICE 2 
Tabela 20. Estimativa da relação entre a remoção da camada superficial do solo e o respectivo delínio de produtividade

\begin{tabular}{cc}
\hline Remoção do solo & Redução da produtividade \\
\hline cm & $\%$ \\
5 & 15 \\
10 & 22 \\
15 & 30 \\
20 & 41 \\
25 & 57 \\
30 & 75 \\
\hline
\end{tabular}

Fonte: Baseado em Bertoni \& Lombardi Neto (1990). 


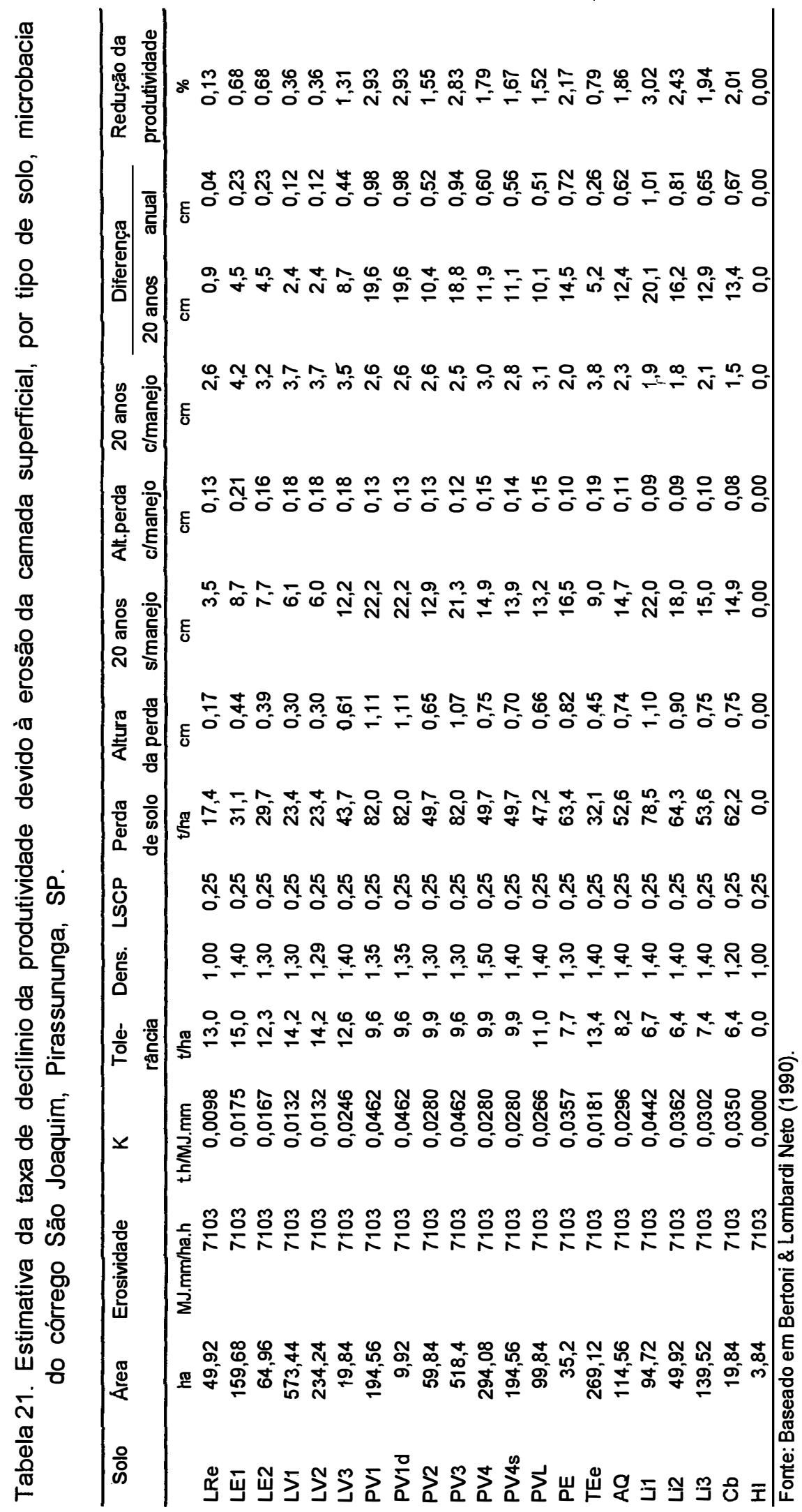


APÊNDICE 3 


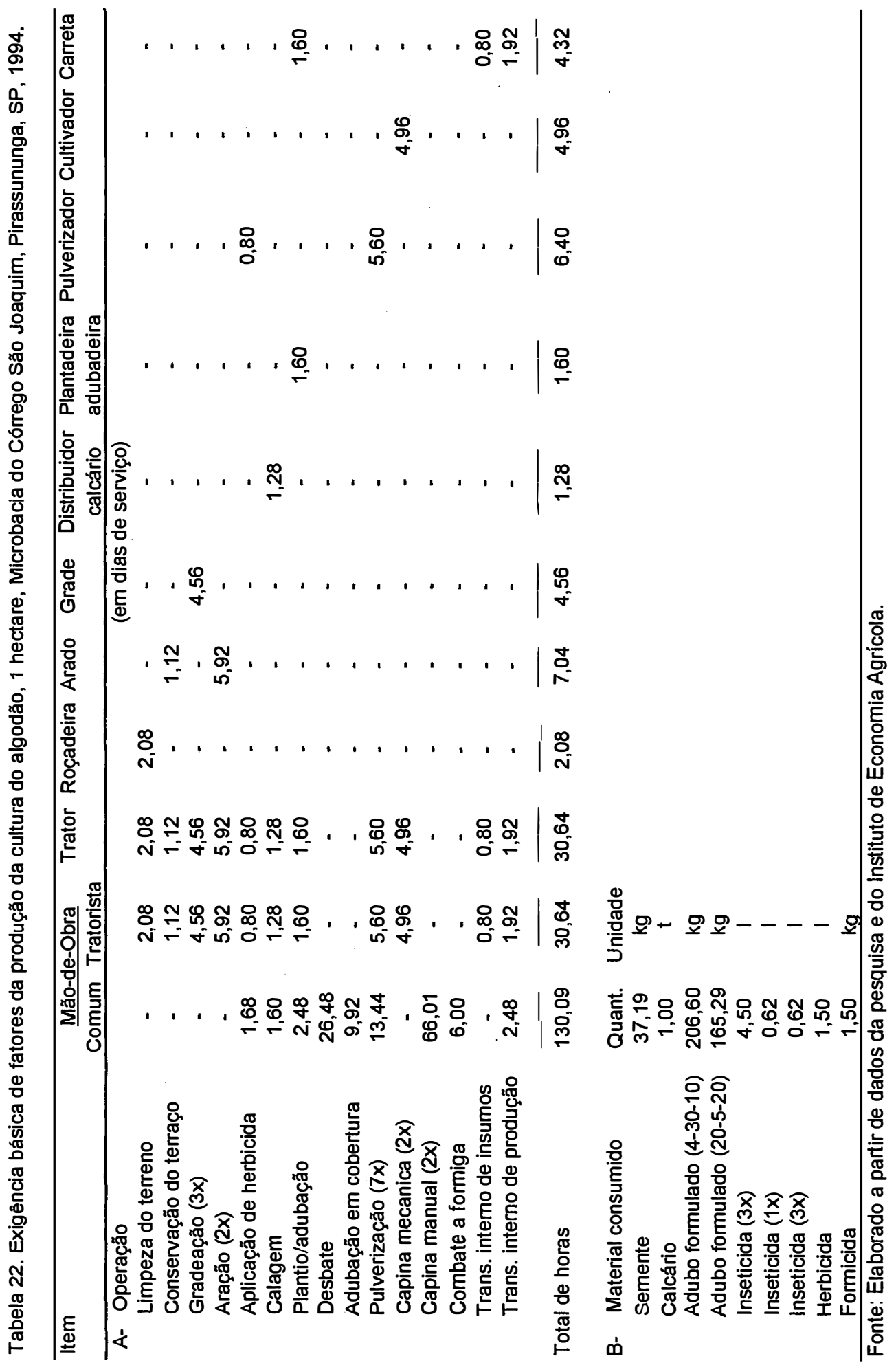




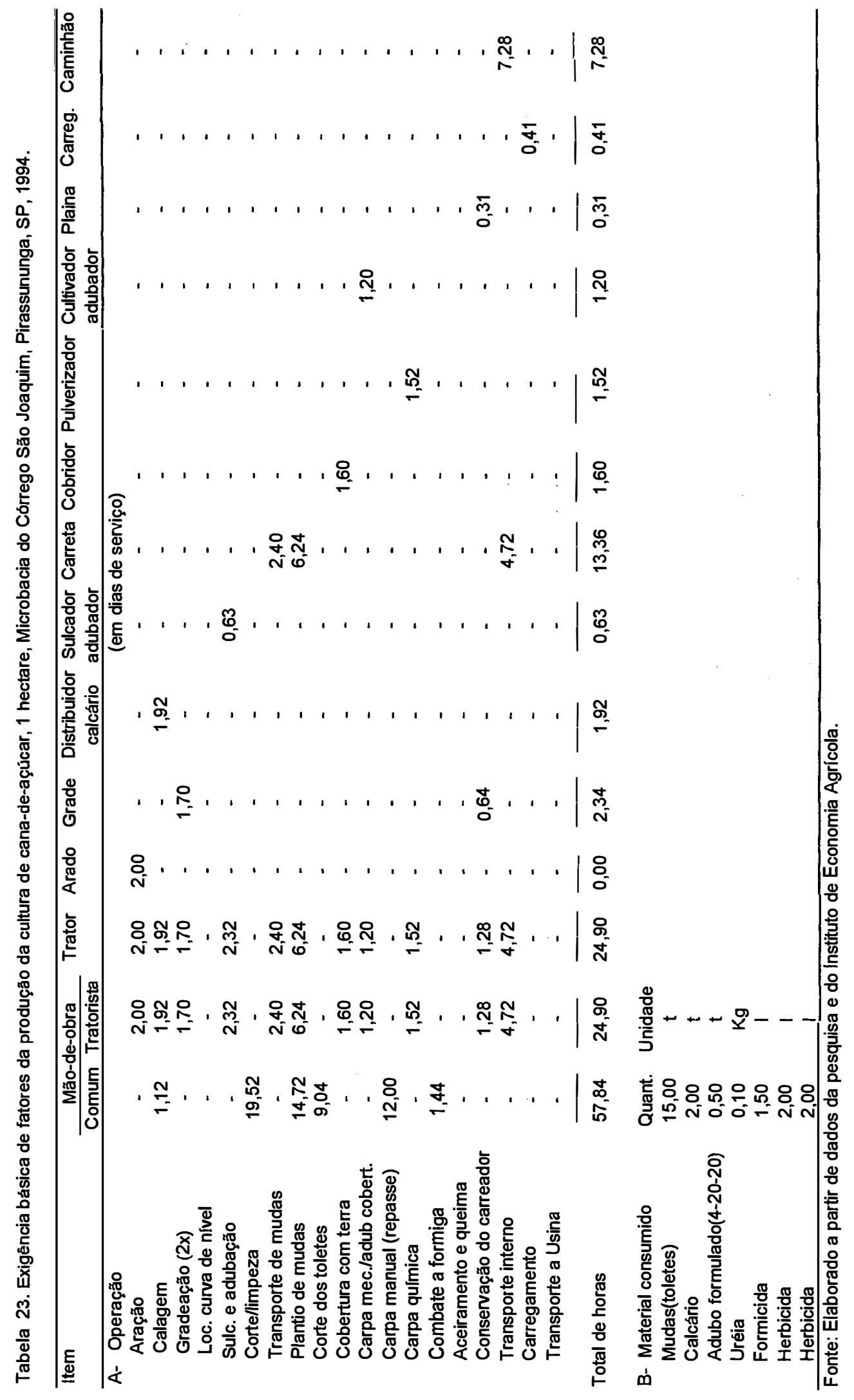




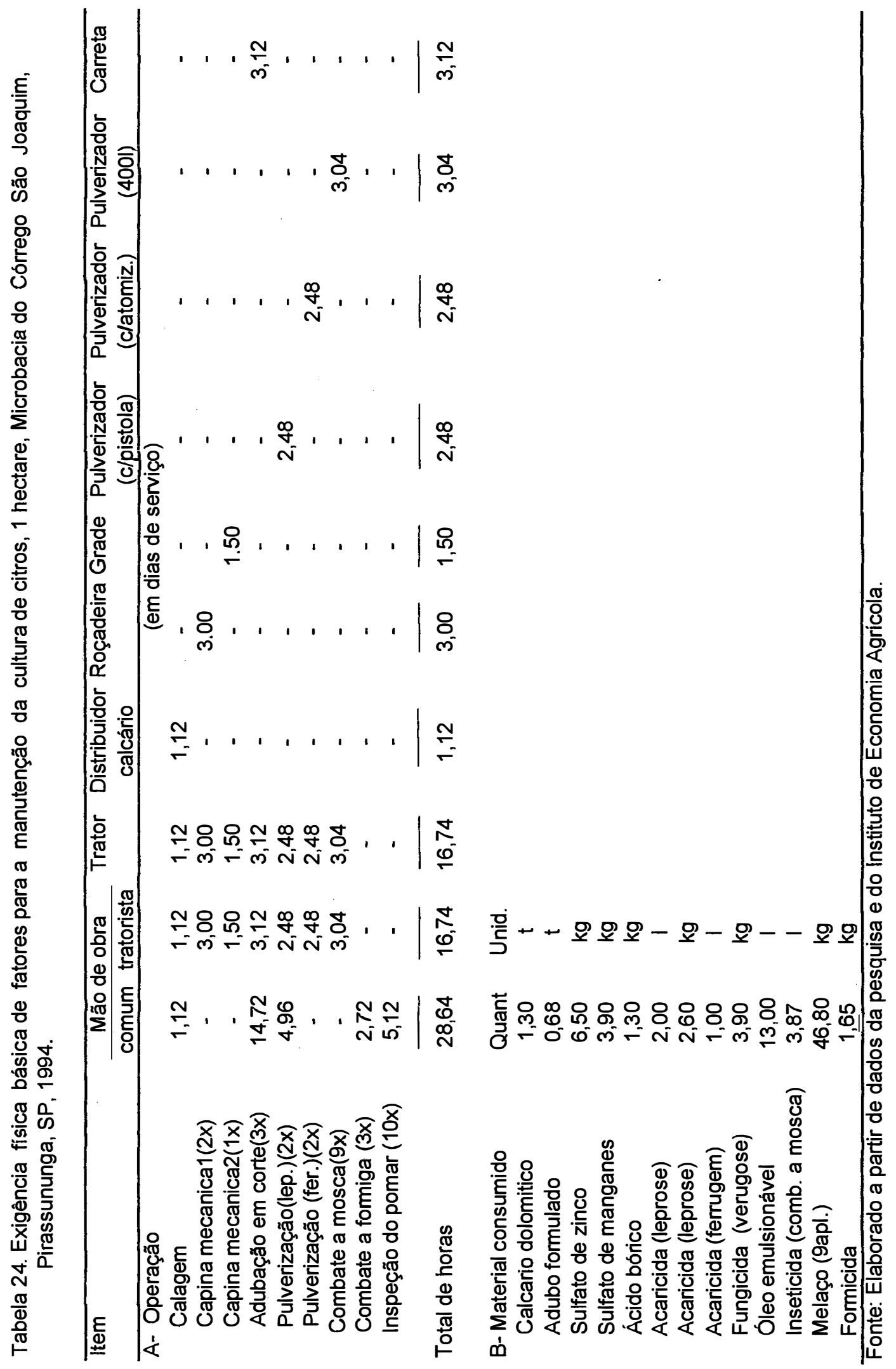




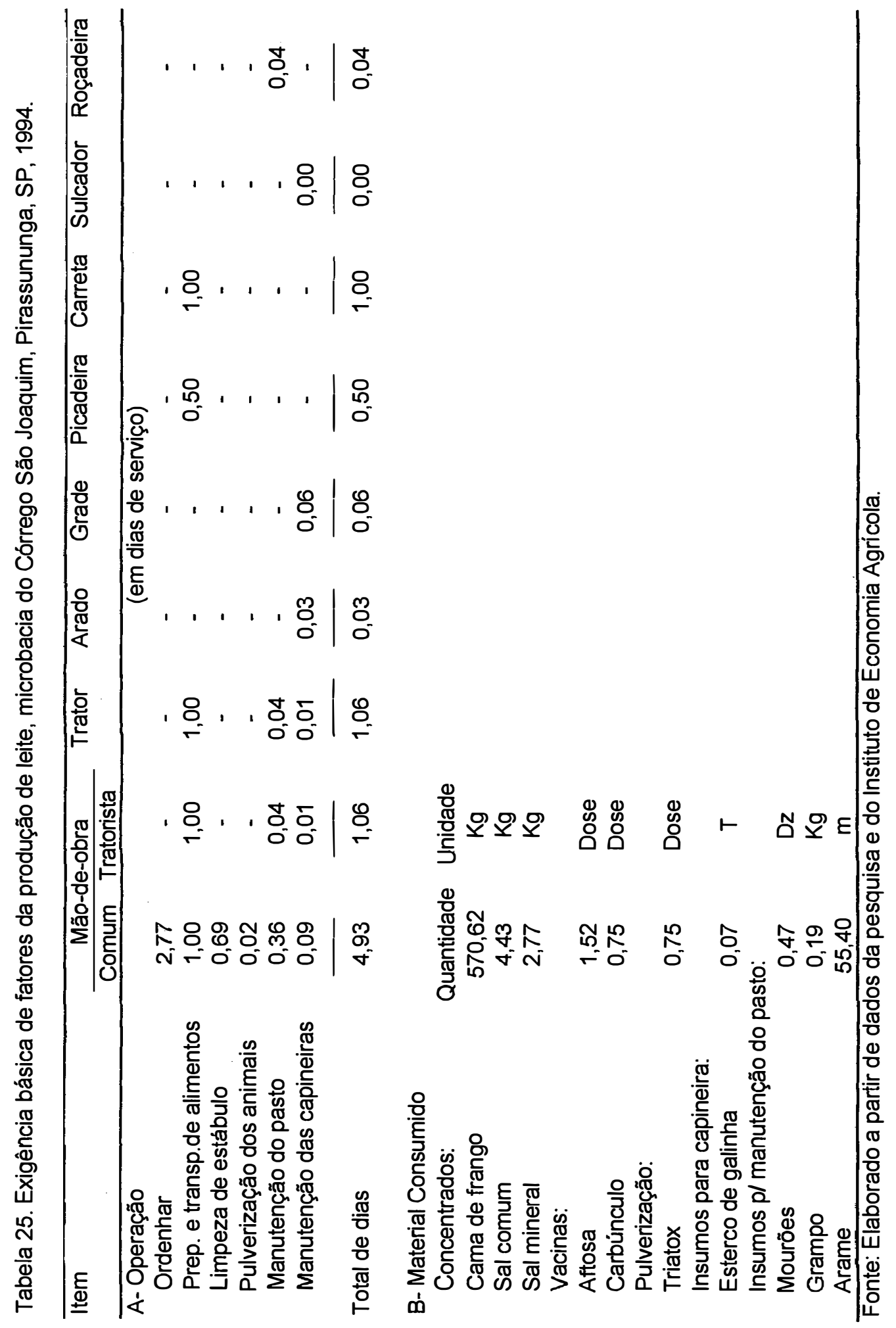




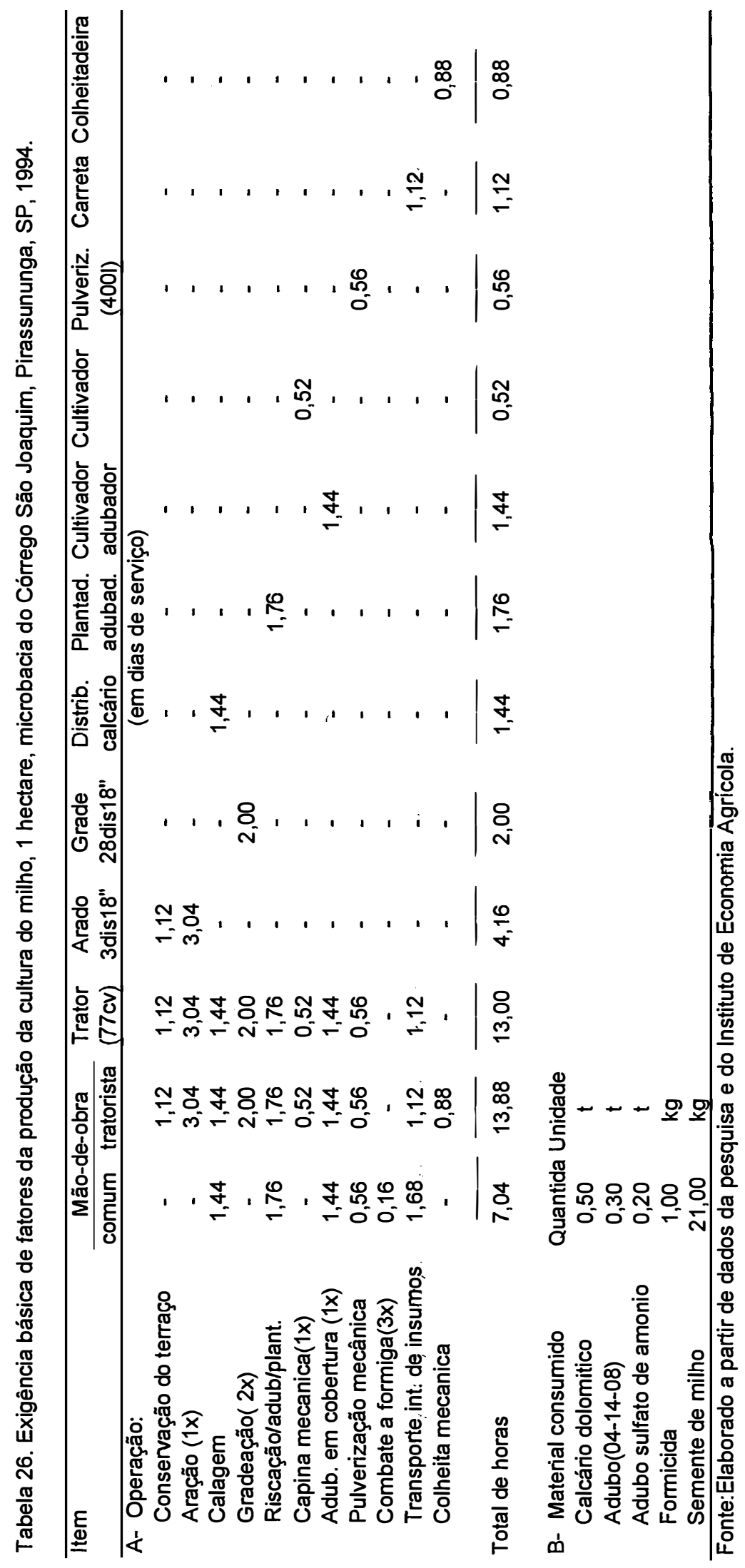




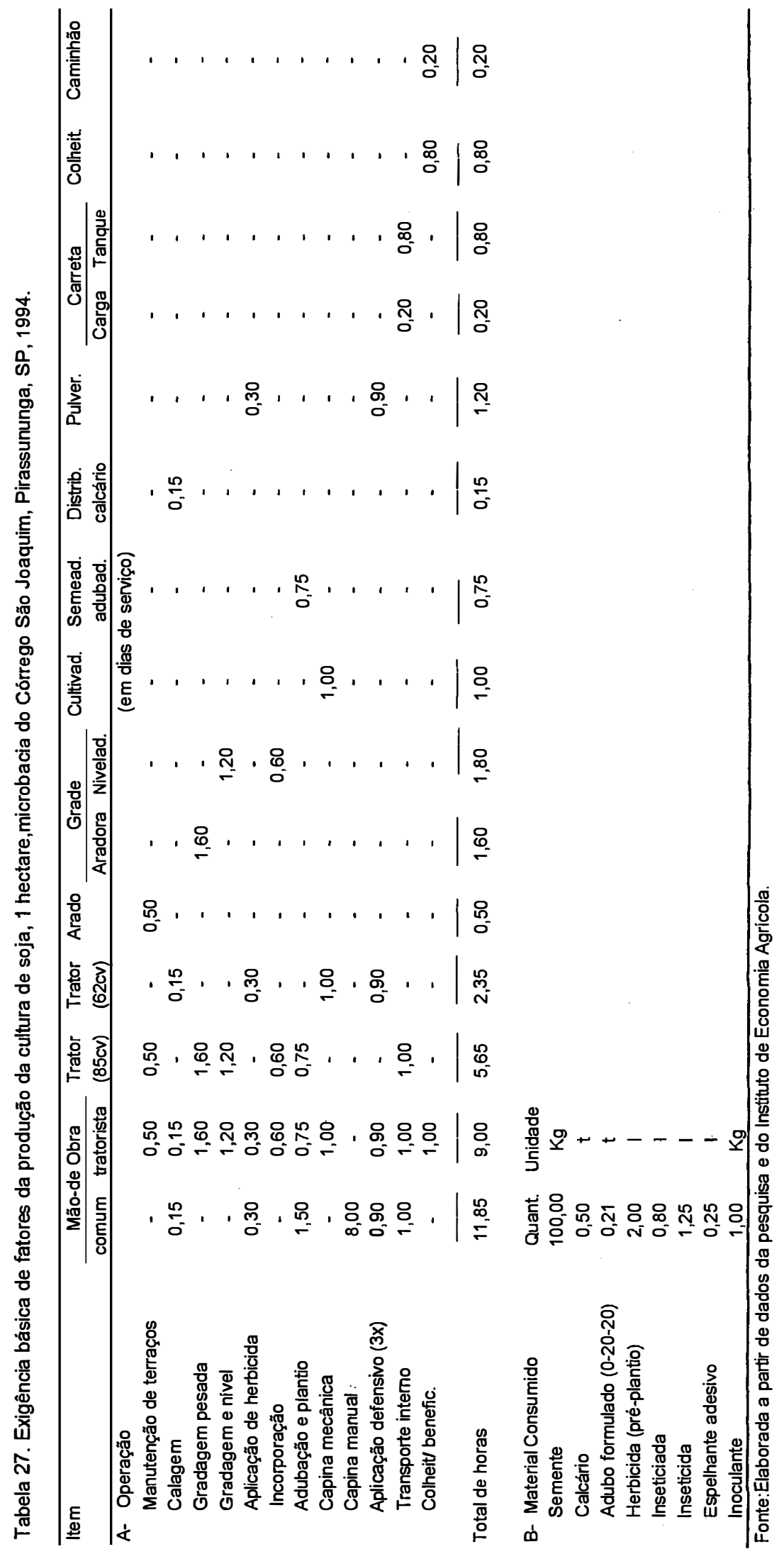




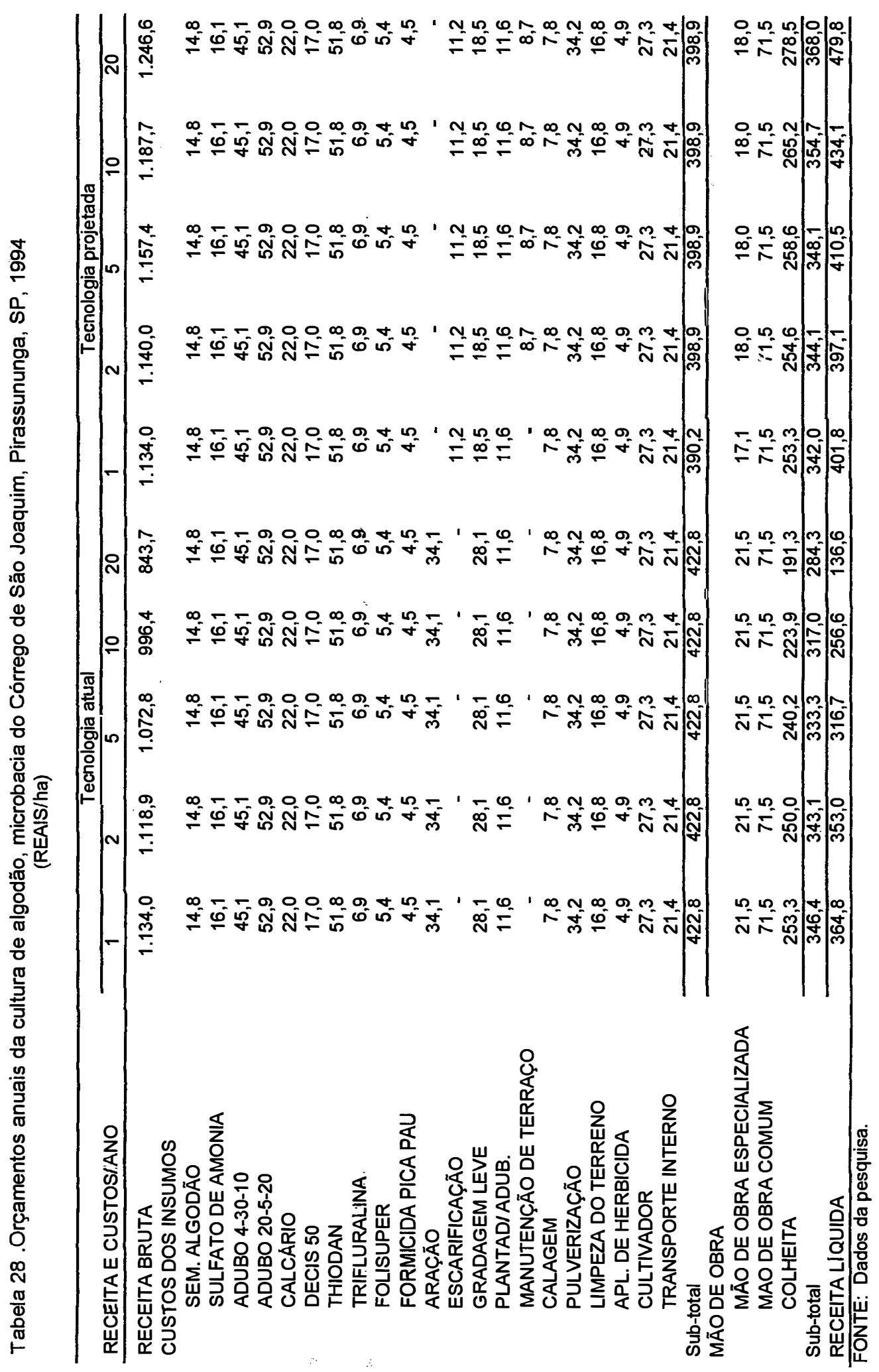




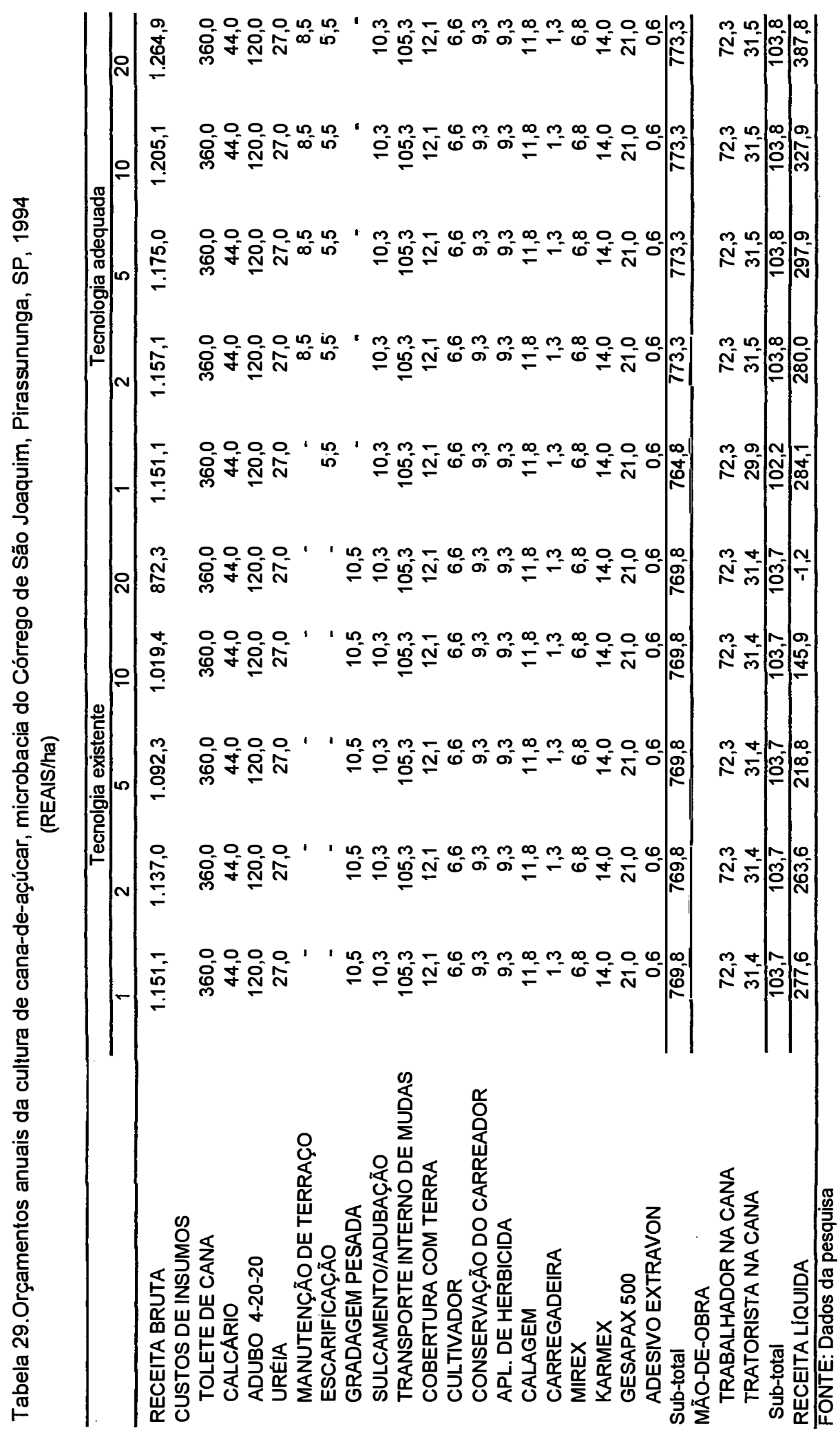




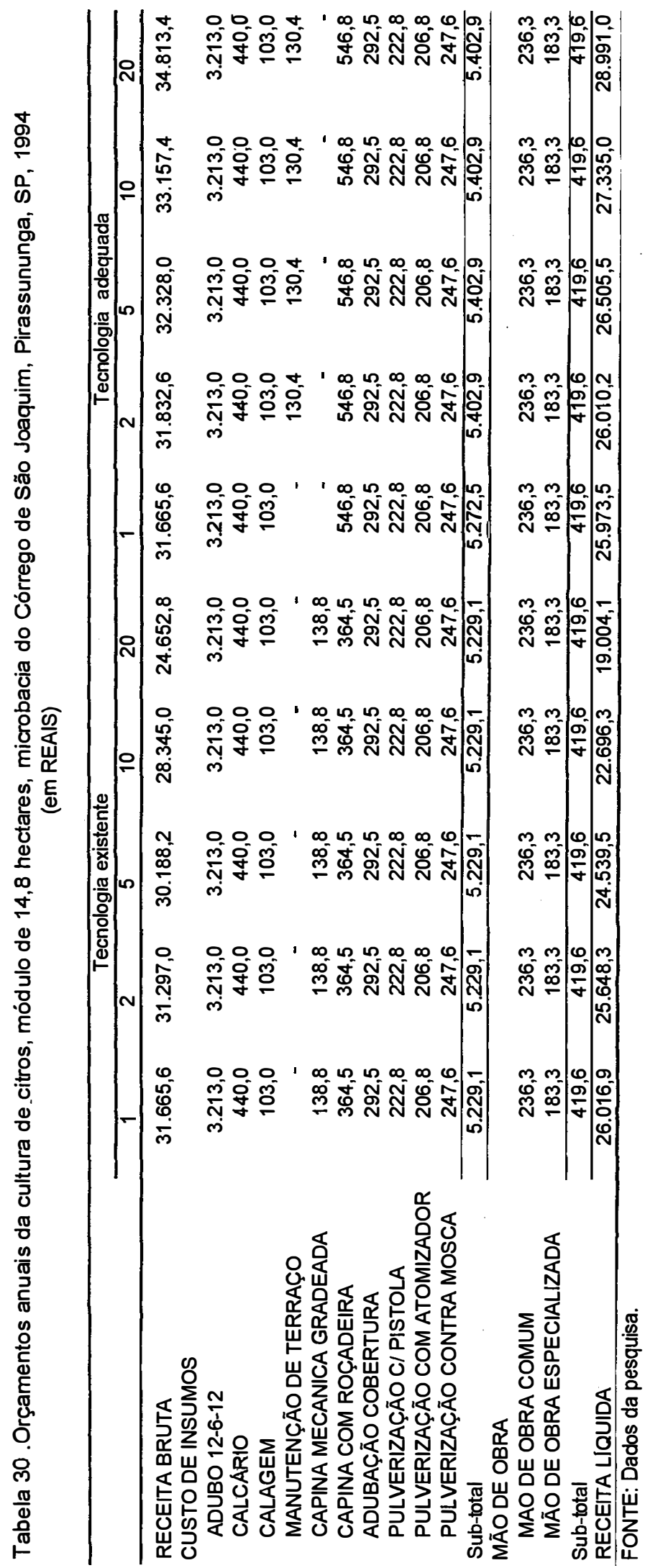




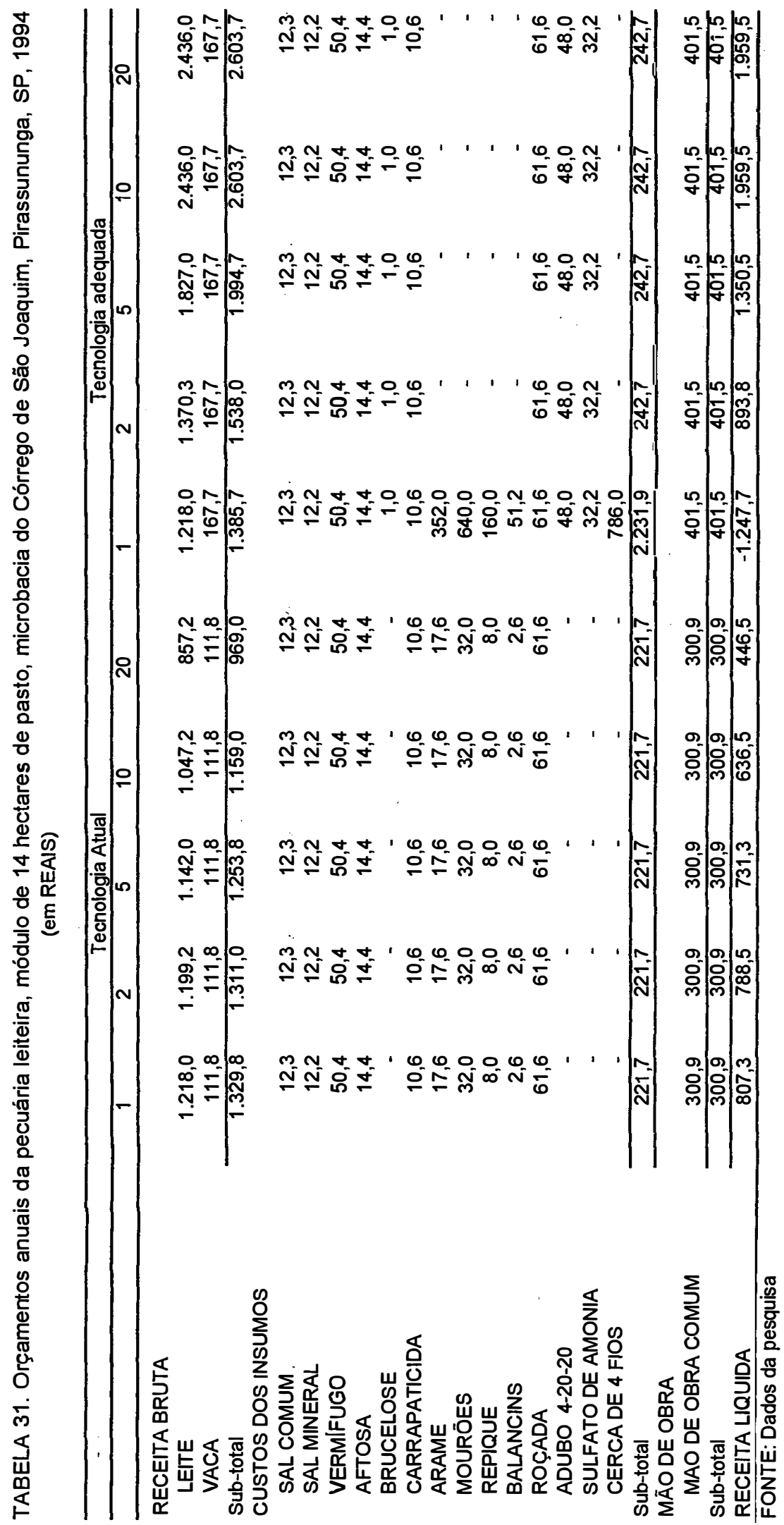




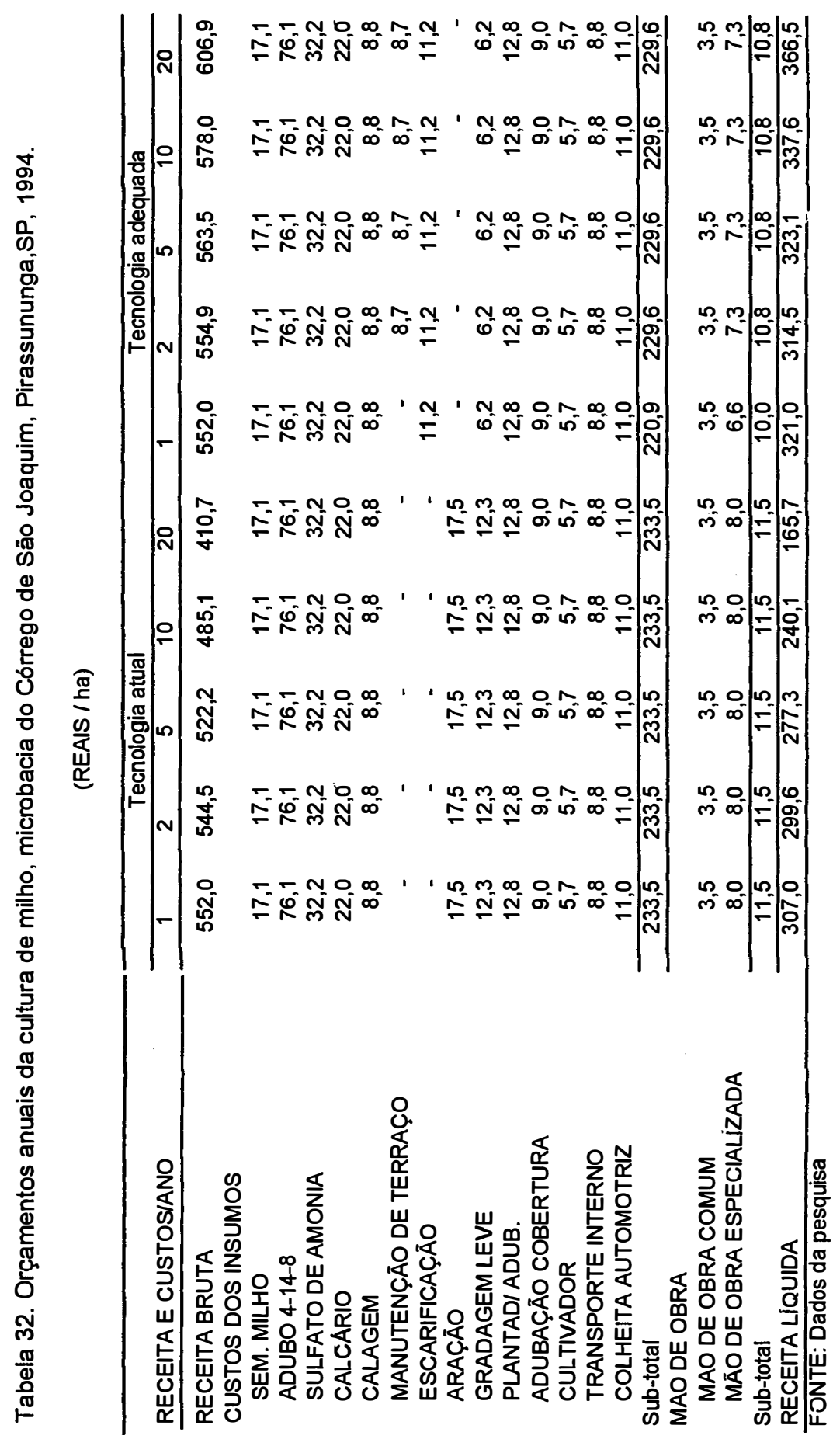




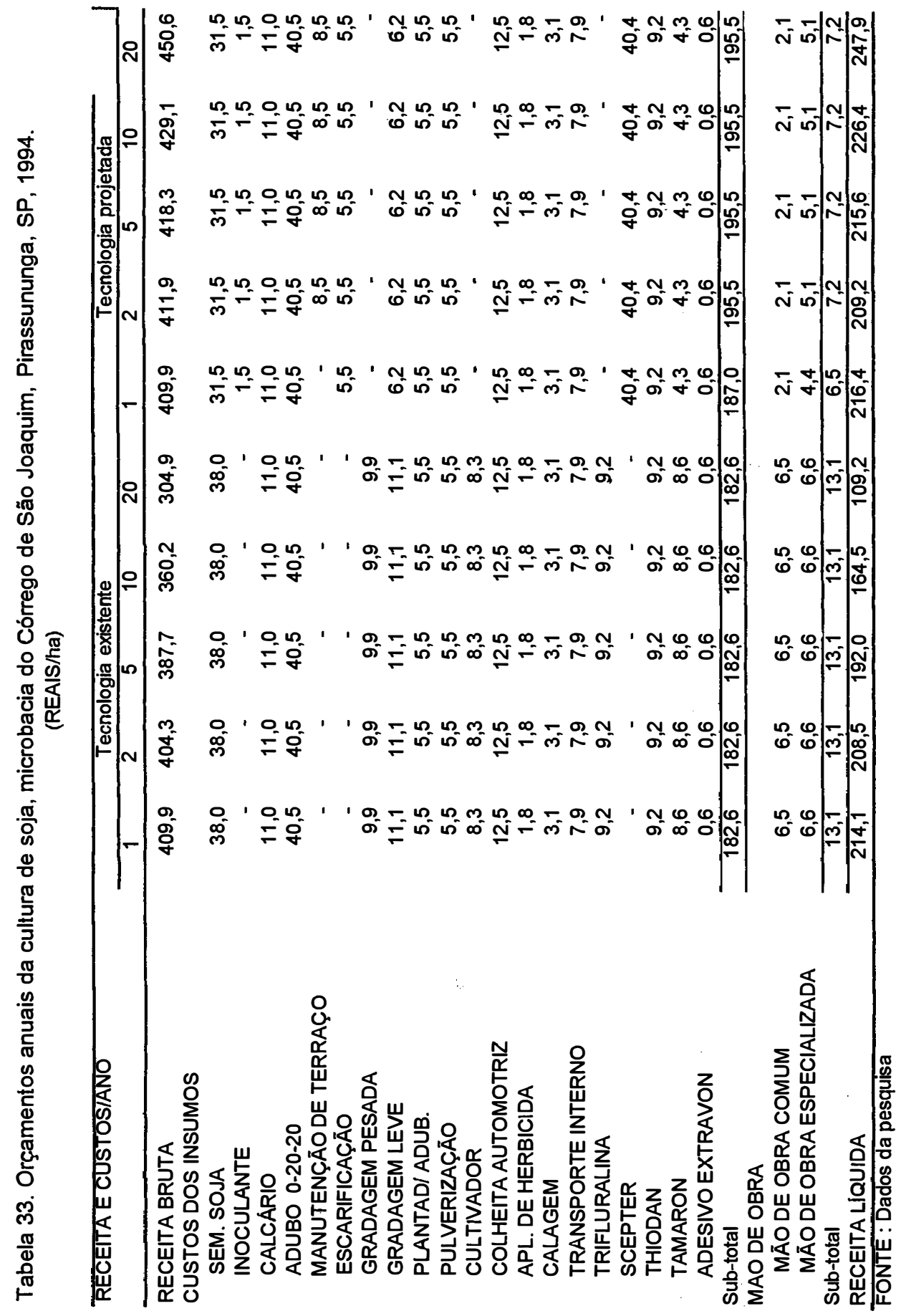

